University of South Florida

DIGITAL COMMONS @ UNIVERSITY OF SOUTH FLORIDA
Digital Commons @ University of South Florida

$10-1-2015$

\title{
Synthesis of Research on the Use of Idle Reduction Technologies in Transit
}

CUTR

Follow this and additional works at: https://digitalcommons.usf.edu/cutr_nctr

\section{Recommended Citation}

"Synthesis of Research on the Use of Idle Reduction Technologies in Transit," National Center for Transit Research (NCTR) Report No. CUTR-NCTR-RR-2014-05, Center for Urban Transportation Research, University of South Florida, 2015.

DOI: https://doi.org/10.5038/CUTR-NCTR-RR-2014-05

Available at: https://scholarcommons.usf.edu/cutr_nctr/66

This Technical Report is brought to you for free and open access by the National Center for Transit Research (NCTR) Archive (2000-2020) at Digital Commons @ University of South Florida. It has been accepted for inclusion in Research Reports by an authorized administrator of Digital Commons @ University of South Florida. For more information, please contact digitalcommons@usf.edu. 


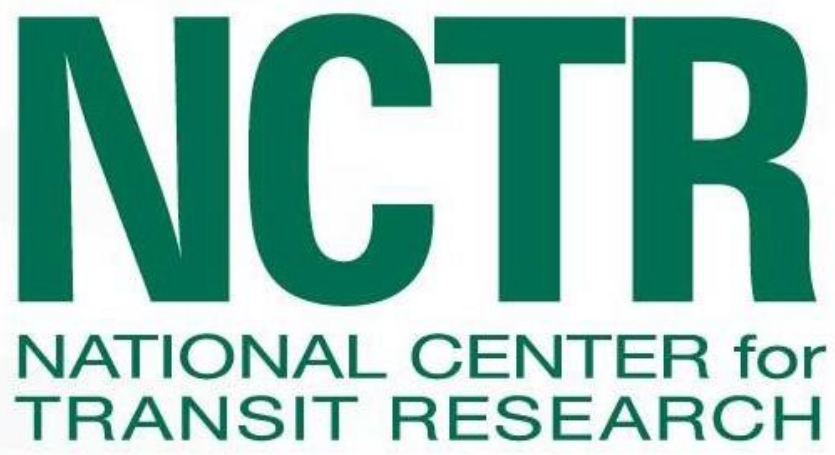

Synthesis of Research on the Use of Idle Reduction Technologies in Transit

Final Report

October 2015

PROJECT NO.

2117-905RO-2

PREPARED FOR

National Center for Transit Research (NCTR) 


\section{Synthesis of Research on the Use of Idle Reduction Technologies in Transit}

Prepared for:

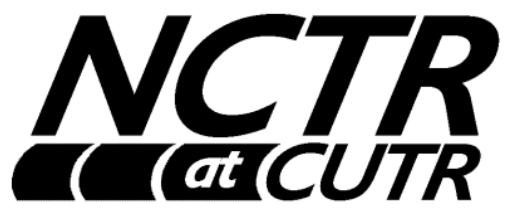

National Center for Transit Research

University of South Florida

Joel Volinski, Project Manager

Prepared by:

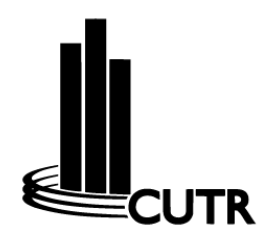

Center for Urban Transportation Research

University of South Florida

Alexander Kolpakov, PI, Research Associate

Stephen L. Reich, Co-PI, Program Director

Final Report

October 2015 


\section{Disclaimer}

The contents of this report reflect the views of the authors, who are responsible for the facts and the accuracy of the information presented herein. This document is disseminated under the sponsorship of the University of South Florida's National Center for Transit Research (NCTR) in the interest of information exchange. The University of South Florida and the National Center for Transit Research assume no liability for the contents or use thereof.

The opinions, findings, and conclusions expressed in this publication are those of the authors and not necessarily those of the National Center for Transit Research. 


\section{Technical Report Documentation}

\begin{tabular}{|c|c|}
\hline 2. Government Acce & 3. Recipient's Catalog No. \\
\hline $\begin{array}{l}\text { 4. Title and Subtitle } \\
\text { Synthesis of Research on the Use of Idle Reduction } \\
\text { Technologies in Transit }\end{array}$ & $\begin{array}{l}\text { 5. Report Date } \\
\text { October } 2015\end{array}$ \\
\hline 6. Performing Organization Code & \\
\hline $\begin{array}{l}\text { 7. Author(s) } \\
\text { Alexander Kolpakov, Stephen L. Reich }\end{array}$ & $\begin{array}{l}\text { 8. Performing Organization Report No. } \\
\text { NCTR 2117-905R0-2 }\end{array}$ \\
\hline $\begin{array}{l}\text { 9. Performing Organization Name and Address } \\
\text { Center for Urban Transportation Research (CUTR) } \\
\text { University of South Florida } \\
4202 \text { East Fowler Avenue, CUT100 } \\
\text { Tampa, FL 33620-5375 }\end{array}$ & 10. Work Unit No. (TRAIS) \\
\hline 11. Contract or Grant No. & \\
\hline $\begin{array}{l}\text { 12. Sponsoring Agency Name and Address } \\
\text { National Center for Transit Research } \\
\text { University of South Florida } \\
4202 \text { East Fowler Avenue, CUT100 } \\
\text { Tampa, FL 33620-5375 } \\
\text { Research and Innovative Technology Administration } \\
\text { U.S. Department of Transportation } \\
\text { Mail Code RDT-30, } 1200 \text { New Jersey Ave SE, Room E33 } \\
\text { Washington, DC } 20590-0001 \\
\end{array}$ & $\begin{array}{l}\text { 13. Type of Report and Period Covered } \\
\text { Final Report } 10 / 31 / 2014-11 / 1 / 2015\end{array}$ \\
\hline 14. Sponsoring Agency Code & \\
\hline 15. Supplementary Notes & \\
\hline 16. Abstract & \\
\hline $\begin{array}{l}\text { There are several potential ways to reduce vehicle tailpipe emiss } \\
\text { older engines, tightening emission standards, installing pollution } \\
\text { others, but the most direct method to reduce harmful emissions }\end{array}$ & $\begin{array}{l}\text { ns, including reducing sulfur in fuel, replacing } \\
\text { ontrol equipment on heavy-duty vehicles, and } \\
\text { to limit unnecessary vehicle idling. }\end{array}$ \\
\hline $\begin{array}{l}\text { Technologies that can be installed on-board vehicles to reduce } \\
\text { energy needs or driver utility include direct-fire heaters, auxiliar } \\
\text { on-board batteries, automatic engine shut-off devices, and } \\
\text { electrification also allows the reduction of excessive stationary } \\
\text { with an outside power source to run vehicle accessories without }\end{array}$ & $\begin{array}{l}\text { e amount of idling without sacrificing vehicle } \\
\text { power units (APU), thermal storage systems, } \\
\text { her equipment. Additionally, parking space } \\
\text { ing of heavy-duty vehicles by providing them } \\
\text { nning the main engine. }\end{array}$ \\
\hline $\begin{array}{l}\text { Reduction in idling can be achieved not only by installing special } \\
\text { change in operational procedures. Idle reduction policies may incl } \\
\text { engine after a certain time of idling, improving vehicle schedulin } \\
\text { and other procedures. }\end{array}$ & $\begin{array}{l}\text { ed equipment on vehicles, but also through a } \\
\text { de limiting engine warm-up, shutting down the } \\
\text { and dispatching, minimizing vehicle queuing, }\end{array}$ \\
\hline $\begin{array}{l}\text { Federal, state, and local incentive programs can help with coverin } \\
\text { equipment acquisition and installation. In the U.S., there are } 1 \\
\text { dealing with idle reduction at the federal, state, and local levels. }\end{array}$ & $\begin{array}{l}\text { ome of the incremental costs of idle reduction } \\
\text { laws, regulations programs, and incentives }\end{array}$ \\
\hline $\begin{array}{l}\text { 17. Key Words } \\
\text { Idle reduction, transit, auxiliary power unit, automatic engine } \\
\text { shut-down device, truck stop electrification }\end{array}$ & $\begin{array}{l}\text { 18. Distribution Statement } \\
\text { No restrictions }\end{array}$ \\
\hline \begin{tabular}{|l|l|}
$\begin{array}{l}\text { 19. Security Classification (of } \\
\text { this report) Unclassified }\end{array}$ & $\begin{array}{l}\text { 20. Security Classification } \\
\text { (of this page) } \\
\text { Unclassified }\end{array}$ \\
\end{tabular} & $\begin{array}{l}\text { 21. No. of Pages } \\
80\end{array}$ \\
\hline
\end{tabular}




\section{Metric Conversion}

\begin{tabular}{|c|c|c|c|c|}
\hline SYMBOL & WHEN YOU KNOW & MULTIPLY BY & TO FIND & SYMBOL \\
\hline \multicolumn{5}{|c|}{ LENGTH } \\
\hline in & inches & 25.4 & millimeters & $\mathrm{mm}$ \\
\hline $\mathrm{ft}$ & feet & 0.305 & meters & $\mathrm{m}$ \\
\hline yd & yards & 0.914 & meters & $\mathrm{m}$ \\
\hline mi & miles & 1.61 & kilometers & $\mathrm{km}$ \\
\hline \multicolumn{5}{|c|}{ VOLUME } \\
\hline $\mathrm{fl} \mathrm{oz}$ & fluid ounces & 29.57 & milliliters & $\mathrm{mL}$ \\
\hline gal & gallons & 3.785 & liters & L \\
\hline $\mathrm{ft}^{3}$ & cubic feet & 0.028 & cubic meters & $\mathrm{m}^{3}$ \\
\hline$y d^{3}$ & cubic yards & 0.765 & cubic meters & $\mathrm{m}^{3}$ \\
\hline \multicolumn{5}{|c|}{ NOTE: volumes areater than $1000 \mathrm{~L}$ shall be shown in $\mathrm{m}^{3}$} \\
\hline \multicolumn{5}{|c|}{ MASS } \\
\hline $\mathrm{Oz}$ & ounces & 28.35 & grams & $g$ \\
\hline $\mathrm{lb}$ & pounds & 0.454 & kilograms & $\mathrm{kg}$ \\
\hline $\mathrm{T}$ & short tons $(2000 \mathrm{lb})$ & 0.907 & $\begin{array}{c}\text { megagrams } \\
\text { (or "metric ton") }\end{array}$ & Mg (or "t") \\
\hline \multicolumn{5}{|c|}{ TEMPERATURE (exact degrees) } \\
\hline${ }^{O} \mathrm{~F}$ & Fahrenheit & $\begin{array}{c}5(F-32) / 9 \text { or }(F- \\
32) / 1.8\end{array}$ & Celsius & ${ }^{\circ} \mathrm{C}$ \\
\hline
\end{tabular}




\title{
ACKNOWLEDGMENTS
}

Project Manager

Joel Volinski, NCTR Director

\author{
CUTR Project Team \\ Principal Investigator: Alexander Kolpakov \\ Co-PI: Stephen L. Reich \\ Editing and Support: Jana Huss
}

\section{Working Group}

Transportation Program Evaluation and Economic Analysis (TPEEA)

Center for Urban Transportation Research

University of South Florida 


\section{Executive Summary}

The main objective of this document is to synthesize current research and practical knowledge covering a wide range of issues related to the use of idle reduction technologies in transit vehicles, including, but not limited to, potential benefits and challenges, advantages and limitations of various idle reduction technologies and approaches, critical success factors, and lessons learned by agencies that have implemented such technologies in their fleets. Although idle reduction is not a new concept, the transit industry may need further education to encourage wider adoption of these technologies on transit vehicles.

Many transit agencies around the U.S. have introduced alternative fuel vehicles into their bus fleets and implemented other strategies aiming to reduce energy consumption and GHG emissions and realize fuel cost savings. Although some alternative technologies require significant up-front investment in vehicles and infrastructure, the strategies that focus on minimizing the time that vehicles idle can be implemented rather quickly and with no or little investment.

Although the use of idle reduction technologies in transit is not as common as in the trucking industry, transit application also has great potential for cost savings and environmental benefits. Billions of gallons of fuel are being consumed in the U.S. every year by idling vehicles. Although some idling is unavoidable, idling for passenger convenience can be minimized by the use of various idle reduction devices installed on board on the vehicles. Even a modest reduction in idle time of transit vehicles can offer significant reductions in petroleum consumption nationwide, provide tangible fuel cost savings for transit agencies, and generate public health benefits.

Scientific evidence indicates that vehicle exhaust can adversely affect lung function and may cause allergic reactions and airway constriction, especially for people with asthma. Diesel engines are primary sources of two pollutants monitored by the U.S. Environmental Protection Agency (EPA): nitrogen oxides (NOx) and particulate matter (PM). Both are responsible for a number of environmental and public health problems. NOx is a greenhouse gas (GHG) that contributes to global climate change and to the formation of acid rain and haze.

There are several potential ways to reduce tailpipe emissions, including reducing sulfur in fuel, replacing older engines, tightening emission standards, installing pollution control equipment on heavy-duty vehicles, and others. But the most direct method to reduce harmful emissions is to limit unnecessary idling of vehicles. Although heavy-duty trucks may be the largest contributors to diesel emissions, the amount of idling and the resulting fuel consumption and emissions produced by other heavy-duty vehicles such as transit and school buses is not insignificant.

Several technologies can be installed on-board vehicles to reduce the amount of idling without sacrificing vehicle energy needs or driver utility, including direct-fired heaters, auxiliary power units (APU), thermal storage systems, on-board batteries, automatic engine shut-off devices, and other equipment. The above devices typically can be retrofitted on vehicles already in operation. Additionally, parking space electrification also allows the reduction of excessive 
stationary idling of heavy-duty vehicles by providing them with an outside power source to run vehicle accessories without running the main engine.

These idle reduction technologies are at different levels of maturity, and all have advantages and limitations. APUs and battery-powered systems provide all the needs of a vehicle with little or no emissions, but they are bulky, heavy, and expensive. Direct-fire and coolant heaters are small and inexpensive but can only provide heat. Automatic engine shut-off devices are inexpensive and low-weight, but have low driver acceptance. The cost of idle reduction devices can range from $\$ 1,400$ for an automatic shut-off system to more than $\$ 8,000$ for an APU. Different idle reduction technologies have different payback periods, depending on the idling profile of the fleet, but with the price of diesel at $\$ 3$ per gallon, all technologies are expected to pay for themselves in 2-3 years.

Idling can be reduced not only by equipment installed on board a vehicle but also through policies. Idle reduction policies typically provide for various types of restrictions that limit the amount of idling. Such policies may include limiting engine warm-up, shutting down the engine after a certain time of idling, improving vehicle scheduling and dispatching, minimizing vehicle queuing, and other procedures. Unlike technological solutions, idle reduction policies can be implemented with little or no up-front investment. However, the success of such policies depends heavily on employee compliance.

The Center for Urban Transportation Research (CUTR) at the University of South Florida surveyed 141 fixed-route transit agencies around the U.S. regarding their idle reduction practices and experiences, and asked for their opinions about the effectiveness of idle reduction strategies, obstacles, and existing incentives. In total, 48 agencies responded to the survey and provided meaningful information, a response rate of $34 \%$. All agencies except one completed the survey online, and the remaining agency completed a paper version of the survey.

The survey of transit agencies showed that environmental concerns and saving fuel costs were the two most important reasons for reducing idling by transit fleets, followed by reduction in engine wear and other factors. The same survey also revealed that transit agencies view the nature of fleet operations as the most important obstacle for implementing idle reduction, followed by the lack of understanding of the impact of idling and other challenges. Cost of idle reduction devices and lack of cooperation from employees are the two factors identified by the largest number of survey respondents as the second most important challenge for implementing idle reduction programs.

Automatic engine shut-off is, by far, the most popular type of idle reduction device used by the surveyed transit agencies. More than $61.0 \%$ of agencies that reported using idle reduction technologies use automatic engine shut-off devices. Direct-fired heaters and other idle reduction devices were used by $15.4 \%$ and $19.2 \%$ of agencies that employ idle reduction technologies, respectively.

Reduction in idling can be achieved not only by installing specialized equipment on vehicles but also through a change in operational procedures. Shutting down vehicle engines after 3-5 
minutes of idling was the most popular idle reduction policy implemented by the transit agencies. More than $60.0 \%$ of the surveyed agencies indicated using such a policy to reduce idling. Limiting engine warm-up was the second most popular idle reduction policy, followed by improvements in vehicle queueing and dispatching. The above two policies were used by $31.3 \%$ and $20.8 \%$ of the surveyed agencies, respectively. The survey data show that a quarter of the surveyed agencies are not using any policy to reduce vehicle idling, and more than $40.0 \%$ of the survey respondents reported employing more than one idle reduction policy.

Based on the survey data, transit agencies that implemented idle reduction technologies or policies save an average of 165.6 diesel gallon equivalents, or $\$ 507$, per year per vehicle.

More than half of the surveyed agencies were not aware if their state or local jurisdiction offered any idle reduction incentive, indicating a lack of knowledge on the part of transit agencies. Educating fixed-route transit agencies about the availability of state and local idle reduction incentives may be useful for encouraging wider adoption of idle reduction practices.

Federal, state, and local incentive programs can help to cover some of the incremental costs of idle reduction equipment acquisition and installation. In the U.S., there are 106 laws, regulations programs, and incentives dealing with idle reduction at the federal, state, and local levels. There are a total of 55 incentives, 43 laws, and regulations and one fleet assistance program at the state level. A total of 41 states and the District of Columbia have some kind of incentive or law addressing idle reduction. Accounting for more than $50.0 \%$ of all state incentives, weight exemption is, by far, the most popular type of state incentive. Of the remaining incentives at the state level, $27.3 \%$ are grants, $9.0 \%$ are loans, $7.3 \%$ are tax credits or exemptions, and $5.5 \%$ are either rebates or reimbursements.

State incentives are represented by a combination of regulatory and financial incentives. Explicit restrictions on the amount of idling of heavy-duty vehicles account for $33.7 \%$ of all state idle reduction incentives/regulations, and financial incentives, such as direct grants, rebates, loans, tax credits, and exemptions, account for $27.6 \%$ of all state incentives. Although both regulatory and financial incentives can help achieve desired results, anecdotal evidence suggests that financial incentives are more likely to be successful in achieving the intended goals, especially considering that idle reduction equipment can be rather costly.

To be successful, idle reduction programs need to be focused on specific goals, the amount of the incentive needs to be large enough to cover most of the incremental cost of the idle reduction equipment, the incentive needs to be designed as a direct grant or rebate, idle reduction rules need to be enforceable, and any idle reduction rule should not only prohibit/restrict the activity (idling) but also should provide an alternative. Finally, a successful idle reduction program should always engage employees to ensure their compliance and cooperation. 


\section{Table of Contents}

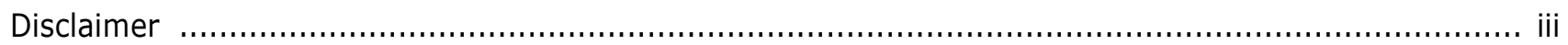

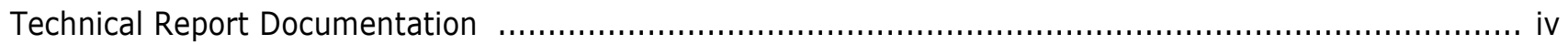

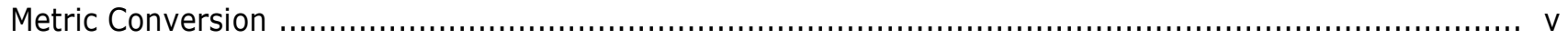

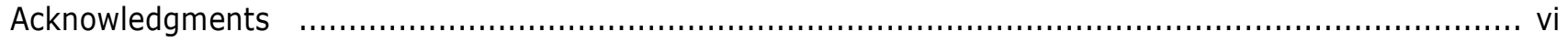

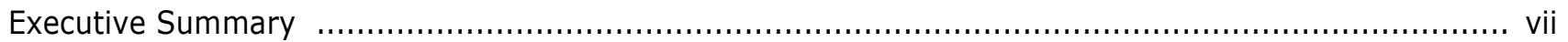

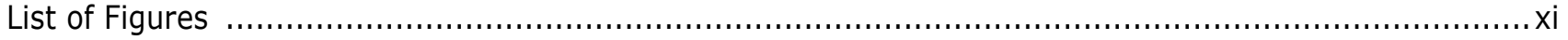

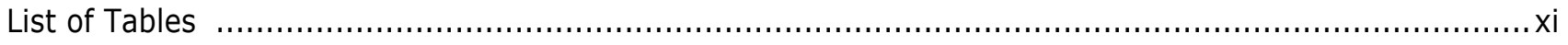

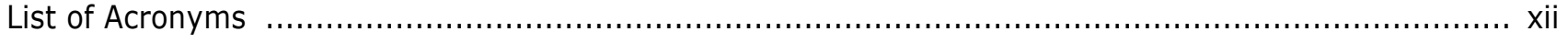

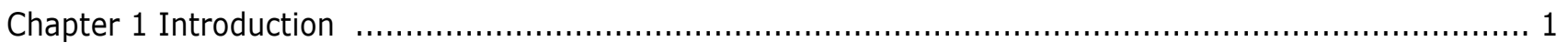

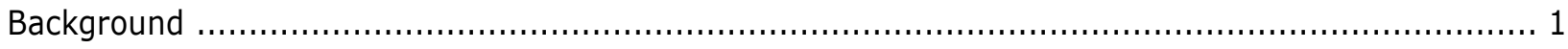

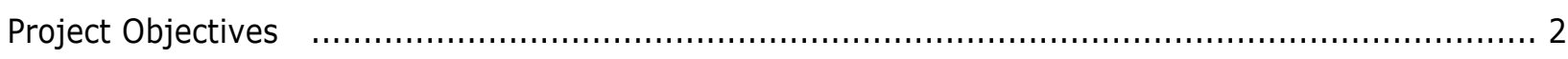

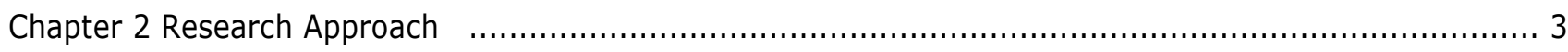

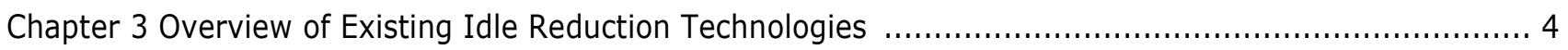

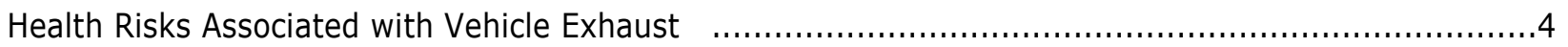

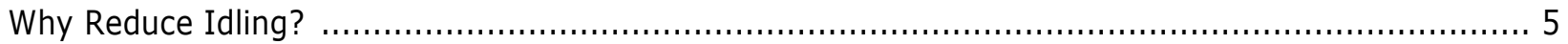

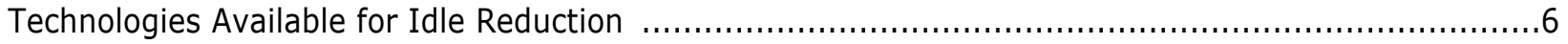

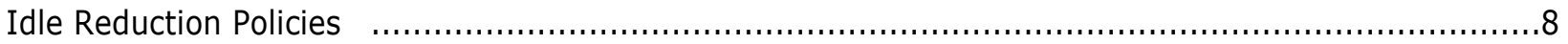

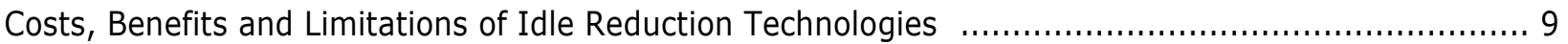

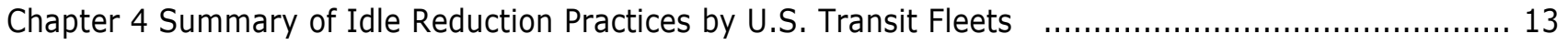

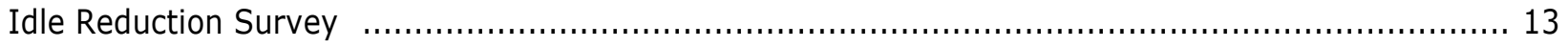

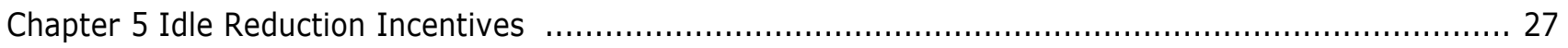

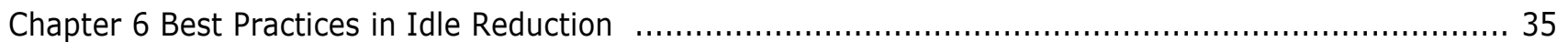

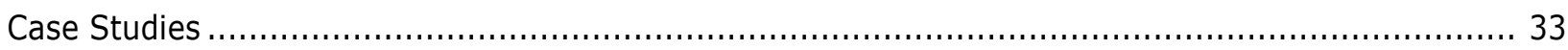

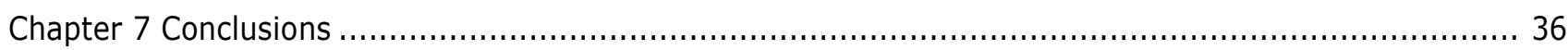

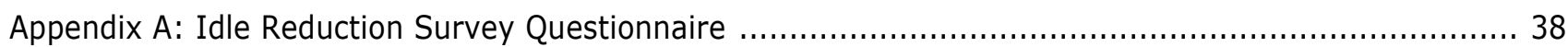

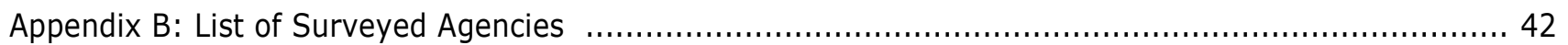

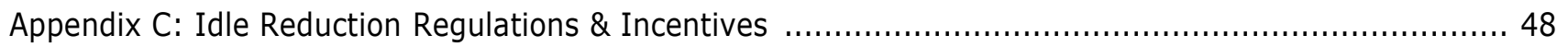

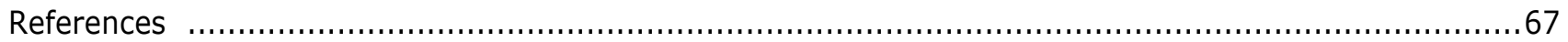




\section{List of Figures}

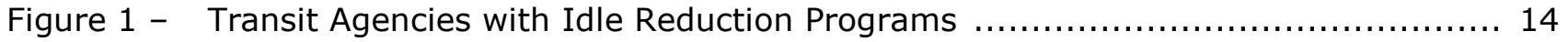

Figure 2 - Most Important Factor for Implementing Idle Reduction Programs ................ 15

Figure 3 - Second Most Important Factor for Implementing Idle Reduction Programs ........ 15

Figure 4 - Comparison of Most and Second Most Important Factors for Implementing Idle

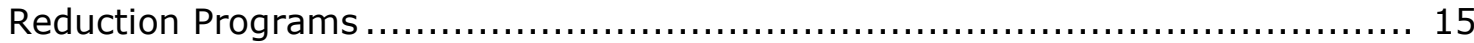

Figure 5 - Most Significant Obstacle to Implementing Idle Reduction Technologies............. 16

Figure 6 - Second Most Significant Obstacle for Idle Reduction Technologies ................ 17

Figure 7 - Comparison of Most Significant and Second Most Significant Obstacles to

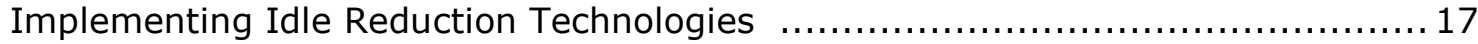

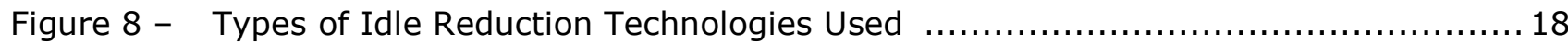

Figure 9 - Idle Reduction Devices Used on Transit Vehicles by Type ......................... 19

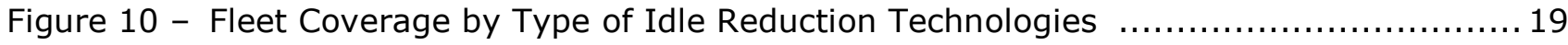

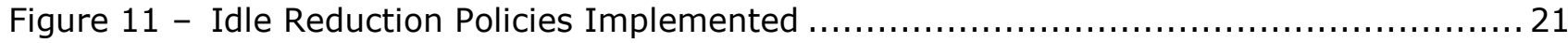

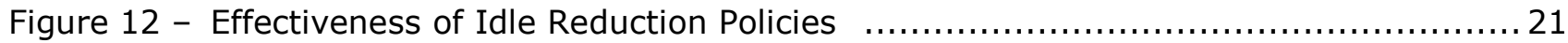

Figure 13 - Additional Benefits of Implementing Idle Reduction Technologies ...................23

Figure 14 - Unexpected Drawbacks Associated with Idle Reduction Technologies.................23

Figure 15 - Availability of State/Local Regulatory Idle Reduction Incentives ..................... 24

Figure 16 - Availability of State/Local Financial Idle Reduction Incentives ........................ 25

Figure 17 - Perceived Effectiveness of State/Local Idle Reduction Incentives ...................26

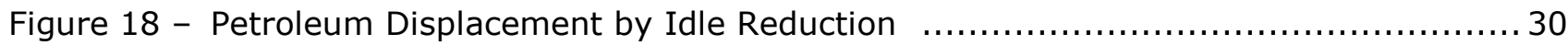

\section{List of Tables}

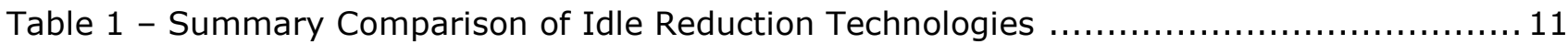

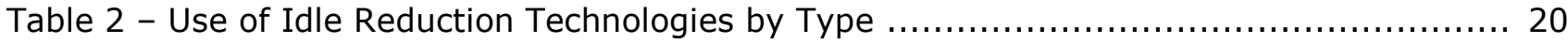

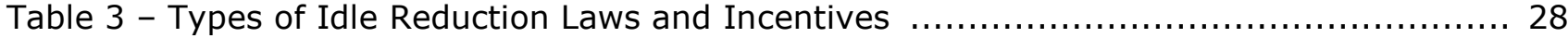




\title{
List of Acronyms
}

\author{
A/C - Air Conditioning \\ APU - Auxiliary Power Unit \\ $\mathrm{CO}_{2}$ - Carbon Dioxide \\ CUTR - Center for Urban Transportation Research \\ DOE - Department of Energy \\ EPA - Environmental Protection Agency \\ EPS - Electrified Parking Space \\ ETS - Electrified Truck Stop \\ FTA - Federal Transit Administration \\ GGE - Gasoline Gallon Equivalent \\ GHG - Greenhouse Gas \\ HVAC - Heating, Ventilating and Air Conditioning \\ IR - Idle Reduction \\ MPG - Miles per Gallon \\ NTD - National Transit Database \\ NOx - Nitrogen Oxides \\ PM - Particulate Matter \\ SOFC - Solid Oxide Fuel Cell
}




\section{Chapter 1 \\ Introduction}

\section{Background}

The nation's transportation system is heavily reliant on petroleum-based energy sources that are finite, not always abundant domestically, subject to volatile price changes, and produce harmful emissions resulting in climate issues and health concerns. Issues of energy conservation and reduction in greenhouse gas (GHG) emissions have become centers of attention in recent years, and public transportation plays a vital role in achieving these goals. Transit agencies and funding entities around the U.S. continue to be under pressure to run a more sustainable and environmentally-friendly operation in the urban environment. In addition, reducing energy consumption of transit vehicles can provide substantial cost savings for transit agencies struggling with funding shortfalls and the increased demand for transit service.

Many transit agencies around the U.S. have introduced alternative fuel vehicles into their bus fleets and implemented other strategies aiming to reduce energy consumption and GHG emissions and realize fuel cost savings. However, a shift towards alternative fuel transit technologies requires significant up-front investment in vehicles and infrastructure and may not always result in overall cost savings to the transit agencies in the short term. On the other hand, the strategies that focus on minimizing the time that vehicles idle can be implemented rather quickly and with no or little investment. Many idle reduction devices, developed primarily for the trucking industry, also can be used in transit vehicles. In addition to new technologies that can be installed in the vehicles, simple modification of fleet driving behavior can reduce unnecessary engine idling.

Although the use of idle reduction technologies in transit is not as common as in the trucking industry, transit application has great potential for cost savings and environmental benefits. Billions of gallons of fuel are being consumed in the U.S. every year by idling vehicles. Whereas some idling is unavoidable (e.g., idling in congestion), idling for reasons of operator or passenger convenience can be minimized by the use of auxiliary power units (APUs), allowing various vehicle accessory systems to run from battery(s) rather than the engine generator. Even a modest reduction in idle time of transit vehicles can offer significant reductions in petroleum consumption nationwide, provide tangible fuel cost savings for transit agencies, and generate public health benefits. 


\section{Project Objectives}

The main objective of this study was to synthesize current research and practical knowledge covering a wide range of issues related to the use of idle reduction technologies in transit vehicles, including, but not limited to, potential benefits and challenges, advantages, and limitations of various idle reduction technologies and approaches, critical success factors, best practices, and lessons learned by the agencies that have implemented such technologies in their fleets. Although idle reduction is not a new concept, the transit industry may need further education to encourage wider adoption of these technologies on transit vehicles.

There currently is no single document that can guide practitioners through the hurdles of decision-making regarding implementation of idle reduction technologies and policies. Such a document will be a useful resource to public transportation providers, local and state governments, the private sector, and other transit stakeholders exploring various options for fuel savings and GHG reductions. 


\section{Chapter 2 \\ Research Approach}

As a first step, researchers at the Center for Urban Transportation Research (CUTR) at the University of South Florida conducted a literature review of the existing theoretical and practical knowledge on the use of idle reduction technologies and methods in the United States. The reviewed documents included published and unpublished academic papers, presentations, and conference proceedings as well as industry news articles, transit agency press releases, and government reports.

The researchers reviewed and summarized known financial and non-financial incentives related to idle reduction technologies at the federal, state, and local levels. All the search efforts were focused on public sources of information that were readily available.

In addition to reviewing the literature, CUTR researchers surveyed 141 fixed-route transit agencies around the U.S. regarding their idle reduction practices and experiences and gathered their opinions about the effectiveness of idle reduction strategies, obstacles, and existing incentives. The survey questions that were sent to the agencies are provided in Appendix A.

The surveyed agencies represent all 10 regions defined in the National Transit Database (NTD) to provide even coverage. A full list of agencies that received the survey is provided in Appendix B. The survey was conducted electronically. A link to the electronic survey was sent (through e-mail) to the agencies on March 31, 2015, and agencies were given 4 weeks to complete it. Overall, 48 responses were received, constituting a $34 \%$ response rate.

The results of the literature review and the transit agency survey are summarized in this report that is assembled with the level of detail appropriate for a synthesis study rather than a detailed technical analysis.

It is anticipated that CUTR researchers will make reasonable efforts to present the findings of the current research to transit industry professionals and granting agency staff by means of webcast presentations, presentations at industry group meetings, professional conferences, or publications. The goal of this effort will be to communicate the findings to the people that are directly involved in making decisions regarding implementation of idle reduction technologies and, thus, are likely to benefit the most from this knowledge. 


\section{Chapter 3 \\ Overview of Existing Idle Reduction Technologies}

Idling refers to running a vehicle engine when the vehicle is not in motion. Vehicles idle for various reasons: to warm-up the engine after starting, to maintain comfortable cabin temperature ( $\mathrm{A} / \mathrm{C}$ or heater), to operate vehicle equipment, or simply while the vehicle is stopped at traffic light or stuck in traffic. Some types of idling can be avoided while others cannot. Regardless of the reason for idling, an idling vehicle consumes fuel and pollutes air with engine exhaust, while getting zero miles per gallon (mpg).

An idling truck or bus consumes, on average, one gallon of diesel fuel per hour (1). The U.S. Department of Energy (DOE) estimates that $2 \%$ of all fuel consumed by heavy- duty vehicles is consumed while idling (2). Some vehicles idle more than others due to the nature of their operation and government regulations. The Federal Motor Carrier Safety Administration prescribes that drivers operating commercial vehicles need to rest 8-10 consecutive hours per day (3). In most cases, this means idling the vehicle overnight at truck stops while the driver is resting. Consequently, more than $8 \%$ of all fuel used by commercial trucks is consumed while the vehicles are idling (2).

Although long-haul trucks may be responsible for the majority of idling and the bulk of fuel consumed while idling, other types of heavy-duty vehicles, including transit buses, motor coaches, and school buses also contribute to the idling problem.

\section{Health Risks Associated with Vehicle Exhaust}

As issues of global climate change, sustainability, air quality, and public health receive more attention, reducing emissions from vehicle tailpipes is becoming a greater priority for policymakers and regulating agencies. The U.S. Environmental Protection Agency (EPA) tracks six commonly-known pollutants, called criteria pollutants, including ozone, particulate matter $(\mathrm{PM})$, carbon monoxide ( $\mathrm{CO})$, nitrogen oxides ( $\mathrm{NOx}$ ), sulfur dioxide $\left(\mathrm{SO}_{2}\right)$, and lead. Vehicle exhaust is a major source of all of these pollutants, except lead (due to elimination of lead from vehicle gasoline after 1995).

Scientific evidence indicates that vehicle exhaust can adversely affect lung function and may cause allergic reactions and airway constriction, especially for people with asthma. Vehicle exhaust is believed to cause and exacerbate a number of serious illnesses including cardiovascular diseases, asthma, chronic obstructive pulmonary disease, lung cancer and diabetes (4). 
Diesel engines are primary sources of two pollutants monitored by EPA: NOx and PM, which includes coarse particles (PM10) and fine particles (PM2.5). Approximately two-thirds of transportation PM emissions and half of NOx emissions come from diesel engines (5). Heavyduty diesel vehicle account for more than $43 \%$ of NOx and more than $49 \%$ of PM emissions from all on-road vehicles (6).

Both PM and NOx are responsible for a number of environmental and public health problems. NOx is a GHG that contributes to global climate change and the formation of acid rain and haze. Additionally, current scientific evidence links NOx exposure with adverse respiratory effects, especially for people with asthma, resulting in increased hospital admissions and visits to emergency rooms (7).

PM from petroleum combustion is the main cause of haze in urban areas. Particles can be carried by wind over long distances, and settling on water and soil can damage coastal water, rivers, lakes, forests, sensitive plants, and crops. In addition, particulate matter pollution causes significant health concerns. The size of the particles is directly linked to their potential health risk, with small particles (less than 10 micrometers in diameter, e.g., PM2.5) posing the greatest risk because they can get deep into lungs and even into the bloodstream. Numerous scientific studies have linked particle pollution exposure to premature death in people with heart or lung disease, heart attacks, irregular heartbeat, asthma, difficulty breathing, and other health problems (7).

\section{Why Reduce Idling?}

There are several potential ways to reduce tailpipe emissions, including reducing sulfur in fuel, replacing older engines, tightening emission standards, installing pollution control equipment on heavy-duty vehicles, and others. The most direct method to reduce harmful emissions is to limit unnecessary idling of the vehicles.

Idling is done by a variety of vehicles, including passenger vehicles, over-the-road trucks, transit buses and motor coaches, school buses, locomotives, aircraft, marine vessels, off-road construction equipment, and others. Most attention in the literature and government policies is paid to limiting the idling of commercial over-the-road trucks. Although heavy-duty trucks may be the largest contributor to diesel emissions compared to other types of vehicles, this synthesis focuses primarily on transit buses and school buses.

In recent years, idling by transit and school buses have come under increased scrutiny by federal and local regulators because of its negative effect on urban air quality and public health. In the case of school buses, unnecessary idling endangers the health of school children, so reducing idling from school buses is viewed by many as a higher priority than transit buses, as reflected in the literature and government anti-idling initiatives. However, the amount of idling and the resulting fuel consumption and emissions of transit buses is not insignificant. Most transit buses idle while in traffic or at bus stops picking up and dropping passengers. Such type of idling is avoidable, but, in many other cases, transit vehicles idle unnecessarily, and several technology and/or policy solutions exist that can limit such type of idling. 


\section{Technologies Available for Idle Reduction}

There are several technologies that can be installed on-board vehicles to reduce the amount of idling without sacrificing vehicle energy needs or driver utility, including direct-fired heaters, APUs, thermal storage systems, on-board batteries, automatic engine shut-off devices, and other equipment. These technologies are at different levels of maturity, and all have advantages and drawbacks. The above devices typically can be retrofitted on vehicles already in operation. A more detailed review of the listed on-board idle-reduction technologies is provided in the following section of this document.

\section{Direct-Fired Heaters}

Direct-fired heaters, also called fuel-operated heaters or bunk heaters, are small diesel-fired heaters that use standard diesel fuel to run and supplies warm air to the cabin of a vehicle. Additionally, they can also provide heat to heat up engine block while the vehicle engine is not running by heating and circulating engine's coolant fluid. This reduces the amount of idling required to heat up the engine to working temperature after a cold start. Direct-fired heaters can be coupled with a vehicle air conditioning system.

Direct-fired heaters use much less fuel than the vehicle's main engine to provide heat because they supply heat directly by a small combustion flame to heat exchanger. The main vehicle engine must first overcome engine friction, and only part of the waste engine heat is transferred to heating system, making this method of heating the vehicle cabin more fuelinefficient than direct-fired heaters (8). A direct-fired (fuel-operated) heater typically consumes $1 / 16$ of the amount of fuel it takes to idle a typical diesel transit bus (9).

\section{Auxiliary Power Unit (APU)}

An APU (sometimes called a generator) is a small internal combustion engine (usually diesel) that is equipped with a generator and heat recovery to provide electricity and heat (8). An APU provides a power supply for a wide range of vehicle needs, including climate control and electrical power for computers and other on-board equipment, without using the main vehicle engine.

APUs are a proven technology that has been used in the trucking industry for years. An APU typically consumes $0.15-0.18$ gallons of diesel per hour of operation, providing vehicle electrical needs while using less than $5 \%$ of fuel than the idling main engine. 8 In the future it may be possible to use diesel-powered solid oxide fuel cell (SOFC) as a power source in an APU, resulting in even lower fuel usage of APUs. A solid oxide fuel cell (SOFC) produces electricity by an electrochemical reaction directly from oxidizing fuel, providing for a more efficient use of fuel compared to internal combustion engine (10). There are currently several demonstration projects underway investigating the use of SOFCs in auxiliary power units of trucks.

When used in commercial trucks, APUs typically are mounted outside on the truck cab or sleeper. Unlike trucks, transit buses typically do not have a good place on the exterior of the vehicle to put a bulky unit. Therefore, transit application potentially might present difficulties with placement of units on vehicles. To be used on a transit bus, an APU likely will need to be installed in the engine compartment or other internal compartments of the vehicle. 


\section{Thermal Storage Systems}

Thermal storage systems, also known as evaporative coolers, store heating or cooling energy transferred by the vehicle engine while the vehicle is being driven and can provide this energy when the engine is turned off. Thermal storage systems can supply heating or cooling while the main engine is turned off, but not the electrical power. These units are typically larger than direct-fired heaters and are comparable in size to APUs. One drawback of such systems is that their effectiveness is highly dependent on the vehicle duty cycle. For example, if the air conditioning (or heat) is not used during vehicle operation, the thermal storage unit will not be able to provide air conditioning (or heat) after the engine is turned off (8).

\section{On-Board Battery}

An on-board battery is an extra battery or similar electrical power storage device, in addition to the main battery, that serves as a stored energy source for heating, cooling, and other electrical needs of the vehicle when the main engine is turned off. The power from the battery does not produce emissions and lasts for the duration of the battery charge. The battery may be recharged from an external electrical outlet or may have the capability to be recharged from the vehicle engine during its normal operation.

\section{Automatic Engine Shut-Off}

Automatic engine shut-off, also called automatic engine start-stop controls, is a device that can be programmed to automatically turn an engine off and on after a predetermined amount of time or at a certain temperature setting or based on other parameters (such as battery charge) (11). For example, an automatic engine start-stop device can sense the temperature inside a vehicle and turn the engine on or off, depending if that temperature is too warm or too cold.

Although features may vary depending on the manufacturer, many units have different modes of operation. For example, under "engine mode," the engine is automatically started if the engine oil or battery voltage falls below a certain level. Under the "cabin comfort" mode, a thermostat starts and stops the engine to maintain the desired cabin temperature. Under the "mandatory shutdown" mode, the engine will automatically shut down after a pre-set number of minutes. In extreme temperatures, however, the use of such devices provides only minimal fuel savings. Additionally, these devices may increase engine wear (12).

\section{On-site Electrification}

On-site electrification is a solution that allows the reduction of excessive idling of heavy-duty vehicles. This option involves the installation of multiple electric outlets in the places where heavy-duty vehicles typically are stationed for a long time (e.g., overnight) to allow vehicle operators to simply "plug-in" and power heaters, air conditioners, lights, and other accessories from an outside power source rather than from the running engine.

This option generally is used to reduce overnight idling of long-haul trucks at truck stops. However, on-site electrification also may have potential application for transit buses. Installing electric outlets for powering vehicle accessories at bus depots, maintenance facilities or other places where transit vehicles are stationed for extended periods of time may help reduce 
unnecessary idling during the time when transit vehicles are being maintained or prepared for service.

Electrified truck stops (ETS) are specific rest areas that provide power to trucks using off-thevehicle infrastructure. Generally, there are two ways the facility can supply power to stationed vehicles:

- Single Unit Electrified Parking Space (EPS), also known as "full service" system, provides power and climate control through a window unit that supplies processed air to the vehicle's cabin. The window unit also can provide internet access, television, and other capabilities.

- Dual Unit EPS provides power by remote power hookups for vehicles that have shorepower capabilities. This requires that heating, ventilating, and air conditioning (HVAC) units providing climate control be installed on individual vehicles.

Truck stop electrification requires significant up-front cost for equipping truck stops with ground electric outlets. Dual systems also suffer from a "chicken and egg" dilemma: truck owners will not install necessary equipment when there is no place to plug it in, and truck stop owners are not willing to install costly infrastructure when very few vehicles have the equipment to use it. Overcoming that challenge may require financial incentives reducing the up-front cost of installing the equipment at designated truck parking locations and onboard vehicles.

There are more long-haul trucks than there are truck parking spaces. Since federal rules require a 10 -hour rest period after 11 hours of driving, truckers must park whenever they can, which may not be at designated truck stops. This results in trucks idling overnight in places other than designated truck stop locations. There are roughly 300,000 parking spaces for 500,000+ long-haul trucks in the U.S., and only a small fraction of these spaces are electrified to provide power for parked vehicles (13). Although electrification may reduce overnight truck idling, it cannot entirely eliminate it due to a large number of trucks stopping (and idling) not at designated truck stops.

Finally, electrification of heavy-duty vehicle parking spaces may reduce local emissions by reducing vehicle idling, but it can also increase emissions in other locations due to increased demand for electricity.

\section{Idle Reduction Policies}

Unnecessary idling can be reduced not only with the help of equipment installed on board a vehicle, but also by change of behavior. Idle reduction policies typically refer to various types of restrictions, voluntary or imposed by the government, that limit the amount of idling. Typical idle reduction policies prohibit long idling, setting limits for the duration of idling in certain areas. Both state and local regulations may set limits on the amount of vehicle idling in cities or around schools. Drivers are expected to turn off their engines after a certain period of time. Violators face fines. Some municipalities or organizations prohibit leaving the engine on when no driver or passengers are inside the vehicle. 
A policy may involve explicit restrictions on the allowable time of idling the engine (e.g., no more than five minutes for engine warm-up) or may include operational and logistical procedures such as improved scheduling, dispatching, and routing that minimize vehicle queuing and result in decreased vehicle idling.

Unlike technological solutions, idle reduction policies typically can be implemented with little or no up-front investment, making them very attractive to many organizations with limited budgets. However, the success of idle reduction policies depends entirely on compliance by vehicle operators. Educating vehicle operators about the impacts of idling and the importance of adhering to idling policies and enforcing the policies by penalizing violators may be necessary to ensure that the policy is effective in reducing vehicle idling.

\section{Costs, Benefits, and Limitations of Idle Reduction Technologies}

The cost of idle reduction devices can range from $\$ 1,400$ for automatic shut-off system to more than $\$ 8,000$ for an APU. Vehicle owners can be deterred by the up- front cost of some units. To address this issue, some equipment manufacturers offer their units for lease with an option to buy after few years (8). Although a leasing arrangement may be helpful for reducing the up-front cost of on-board idle reduction equipment, it is not applicable to truck stop electrification requiring high infrastructure cost.

Another potential concern may be the weight and size of idle reduction devices. Some devices are big and heavy, and although the extra weight of the device may not significantly affect vehicle's fuel economy, it can reduce the useful load for weight-limited trucks. To address this concern, many (but not all) states have adopted idle reduction weight exemptions, allowing vehicles equipped with idle reduction devices to exceed maximum vehicle weight rating for up to 400-550 pounds to accommodate the added weight of the equipment.

Although weight may be more relevant to trucks, transit vehicles may be more sensitive to the size of idle reduction devices. Unlike long-haul trucks, the configuration of transit buses does not allow for an easy installation and retrofit of large external devices. Considering that some idle reduction units are large, their transit application may be challenging, if not impossible or impractical.

The trucking industry has been using the above idle reduction devices for years, but they are not very common for transit vehicles. Although these technologies can provide fuel cost savings, they all have drawbacks. In choosing appropriate on-board idle reduction units, transit agencies need to carefully consider their cost, size, weight, and other parameters that may affect their practical use on transit vehicles.

Of the idle reduction devices currently used by trucking industry, the technologies that are potentially transferable to transit bus application are direct-fired heaters, APUs, on-board batteries, and automatic engine shut-off/start-up systems. 
- Direct-fired heaters - the main advantage of direct-fired heaters is that they are very fuel-efficient. Such heaters can often operate for $20+$ hours on one gallon of diesel. The major disadvantage is that they are unable to provide air conditioning and electricity and are useful only in winter months. A direct-fired heater can cost anywhere from $\$ 1,300$ for a small unit to more than $\$ 3,000(11,13)$.

- APUs - the main advantage of APUs is that they can provide all power needs of the vehicle, including heat, cooling, and electricity, thus serving as a survival system. APUs, depending on size, may be mounted externally or internally. The main disadvantage, however, is their weight and cost. An APU weighs more than 300 pounds and may cost $\$ 7,000-\$ 8,000(11,13)$. Although useful to long-haul trucks that often idle overnight to provide a comfortable climate inside the vehicle and supply power to run appliances, such devices may not be well-suited for transit application.

- Battery-powered heating and A/C - the main advantage of battery-powered heating or $A / C$ units is that they can provide all cabin needs while producing no emissions. A battery-powered unit can supply up to 10 hours of power for air conditioning or heating and recharge a battery using the vehicle alternator. However, battery-powered systems are heavy (200-500 pounds) and may cost more than $\$ 7,000$ (11).

- Automatic engine shut-off/start-up system - the main advantages of automatic engine shut-off systems include their small size/weight and relatively low cost. With a size smaller than a laptop computer and a weight less than 30 pounds, such devices can easily fit inside a typical transit bus. Additionally, such devices can be factory-installed by engine manufacturers rather than being retrofitted and typically cost from $\$ 1,400$ to $\$ 4,000$ (11). The main disadvantage, however, is that vehicle operators may interfere with the operation of such devices. Anecdotal evidence suggests that restarting an engine manually immediately after it was shut-off by the system is not uncommon for vehicle operators.

- Electrified parking space - the main advantage of electrified parking spaces is that they provide all the needs of the stationed vehicle without causing local emissions (although causing emissions elsewhere). Disadvantages include the need for designated locations and high capital costs, and they also may require the installation of equipment on board the vehicles. Electrification of existing heavy-duty vehicle parking spaces may cost up to $\$ 2,500$ per spot $(8,13)$.

Advantages, disadvantages, and costs of common types of idle reduction technologies are summarized in Table $1(11,13)$. 
Table 1 - Summary Comparison of Idle Reduction Technologies

\begin{tabular}{|c|c|c|c|c|c|}
\hline Technology & Function & Advantages & Disadvantages & $\begin{array}{c}\text { Cost } \\
(\$)\end{array}$ & \begin{tabular}{|l|} 
Fuel Use \\
(gal/hr)
\end{tabular} \\
\hline $\begin{array}{l}\text { Direct- } \\
\text { fired } \\
\text { heater }\end{array}$ & $\begin{array}{l}\text { Heat for cabin } \\
\text { and/or engine }\end{array}$ & $\begin{array}{l}\text { Small size and } \\
\text { weight, low } \\
\text { emissions }\end{array}$ & $\begin{array}{l}\text { Supplies heat only, } \\
\text { requires battery } \\
\text { power, may be } \\
\text { unreliable when } \\
\text { not equipped with } \\
\text { automatic engine } \\
\text { starting }\end{array}$ & $\begin{array}{c}\$ 1,300- \\
\$ 3,200\end{array}$ & $\begin{array}{c}0.04- \\
0.16\end{array}$ \\
\hline $\begin{array}{l}\text { Auxiliary } \\
\text { power } \\
\text { unit (APU) }\end{array}$ & $\begin{array}{l}\text { Heat and } A / C \\
\text { for cabin, heat for } \\
\text { engine, power for } \\
\text { auxiliary systems }\end{array}$ & $\begin{array}{l}\text { Can be used } \\
\text { anywhere } \\
\text { anytime, recovers } \\
\text { waste heat for } \\
\text { space heating }\end{array}$ & $\begin{array}{l}\text { High weight and } \\
\text { cost }\end{array}$ & $\begin{array}{c}\$ 7,000- \\
\$ 8,000\end{array}$ & $\begin{array}{l}0.08- \\
0.30\end{array}$ \\
\hline $\begin{array}{l}\text { Battery- } \\
\text { powered } \\
\text { heat/A/C }\end{array}$ & $\begin{array}{l}\text { Heat and } \mathrm{A} / \mathrm{C} \text { for } \\
\text { cabin }\end{array}$ & $\begin{array}{l}\text { Provides all } \\
\text { needs, } \\
\text { zero emissions }\end{array}$ & Heavy, high cost & $\begin{array}{l}\$ 7,000- \\
\$ 8,000\end{array}$ & $0-0.17$ \\
\hline $\begin{array}{l}\text { Automatic } \\
\text { engine } \\
\text { shut-off }\end{array}$ & $\begin{array}{l}\text { Controls engine } \\
\text { (start/stop) based } \\
\text { on set time period, } \\
\text { ambient } \\
\text { temperature, } \\
\text { and/or battery } \\
\text { charge }\end{array}$ & $\begin{array}{l}\text { Low weight and } \\
\text { cost, available } \\
\text { from engine } \\
\text { manufacturer }\end{array}$ & $\begin{array}{l}\text { Low driver } \\
\text { acceptance, minimal } \\
\text { benefit in extreme } \\
\text { weather }\end{array}$ & $\begin{array}{c}\$ 1,400- \\
\$ 4,000\end{array}$ & $\begin{array}{l}0.15- \\
0.40\end{array}$ \\
\hline \begin{tabular}{|l|} 
Electrified \\
parking \\
space
\end{tabular} & $\begin{array}{l}\text { Provides heat, } \\
\text { A/C, and power to } \\
\text { parked vehicles }\end{array}$ & $\begin{array}{l}\text { Provides all } \\
\text { needs, quiet, no } \\
\text { local emissions }\end{array}$ & \begin{tabular}{|l|} 
Requires equipped \\
location, may require \\
on-board equipment
\end{tabular} & $\$ 2,500$ & Varies \\
\hline $\begin{array}{l}\text { Heat } \\
\text { recovery }\end{array}$ & Heating & $\begin{array}{l}\text { Very low cost, low } \\
\text { weight and } \\
\text { emissions }\end{array}$ & $\begin{array}{l}\text { Insufficient for } \\
\text { overnight heating }\end{array}$ & $\$ 600$ & Small \\
\hline $\begin{array}{l}\text { Coolant } \\
\text { heater }\end{array}$ & Heat for engine & $\begin{array}{l}\text { Low cost, low } \\
\text { weight and } \\
\text { emissions }\end{array}$ & Only heats engine & $\$ 1,400$ & 0.1 \\
\hline
\end{tabular}

Different idle reduction technologies provide different payback periods to the users depending on the amount of idling and the type of anti-idling technology chosen. However, with the price of diesel of $\$ 3 /$ gallon (at the time of this report), all listed idle reduction technologies are expected to pay for themselves in 2-3 years (13). Payback time will decline if fuel prices rise and will increase in the event of fuel price drops.

The issue of payback is an important consideration, especially for the trucking industry. It has been previously reported that truck owners are interested only in items with a payback time of under two years due to rapid replacement rate of truck fleets (8). A typical small-fleet owner replaces his trucks every three to four years, around the time when the warranty expires. Larger fleets may be replaced even more often. With such a rapid fleet replacement schedule, factoryinstalled units, which are likely to be offered at lower cost, could become more attractive than retrofits.

Although fuel cost saving is the main financial benefit of reduced idling to vehicle owners and fleet operators, idle reduction devices and policies also may reduce vehicle maintenance costs. Routine maintenance can be performed less often and mileage to overhaul can be increased 
on vehicles that idle less. This may lower ongoing vehicle maintenance costs and extend engine life. Additionally, some idle reduction devices have residual value and can be salvaged after a vehicle is retired.

In addition to financial benefits to fleet operators, the use of idle reduction technologies can significantly reduce harmful vehicle emissions. Although some of the discussed idle reduction options cause an increase in emissions in other locations (e.g., where power is generated), the net result still demonstrates the superiority of idle reduction technologies compared to idling. All idle reduction options discussed result in significant reduction of major pollutants. APUs have the highest NOx emission of all the presented idle reduction devices. Yet, the total (vehicle plus upstream) emissions of NOx from APUs is still more than $90 \%$ lower than from idling. Emission of PM can be reduced by half and $\mathrm{CO}_{2}$ by $75 \%$ with the use of idle reduction technologies (13).

All of the above idle reduction technologies have great potential for reducing energy consumption and emissions resulting from long-haul trucks idling overnight. Even direct-fired heaters, typically used only during the coldest months per year, are estimated to reduce petroleum use and $\mathrm{CO}_{2}$ emissions by $40 \%$ over the whole year and by over $85 \%$ during the period when they are used. Auxiliary power units are estimated to reduce energy, petroleum use and $\mathrm{CO}_{2}$ emissions by more than $80 \%$ for the entire year. Electrified parking spaces can result in $70 \%$ reduction in energy consumption and petroleum use, $74 \%$ decrease in $\mathrm{CO}_{2}$ emissions, and almost $99 \%$ reduction in CO emissions ( 8 ). 


\section{Chapter 4 \\ Summary of Idle Reduction Practices by U.S. Transit Fleets}

Of the three types of fleets that are likely to benefit from idle reduction programs, including over-the-road trucks, transit buses, and school buses, transit vehicles are the fleets with the least utilization of idle reduction technologies. This section reviews and summarizes current idle reduction practices implemented by U.S. transit fleets.

\section{Idle Reduction Survey}

To evaluate the use of idle reduction technologies and get a better understanding of the transit fleet perceptions of the benefits and shortcomings of such technologies, CUTR surveyed fixedroute transit agencies around the U.S. CUTR researchers designed a brief electronic survey covering basic questions about fleet experience with idle reduction technologies and policies, as well as an evaluation of effectiveness of various idle reduction methods. The survey consisted of 14 questions, most with multiple choice-type answers, to ensure ease of completion. Additionally, the questions also provided for optional comments. The survey questionnaire is provided in Appendix A.

On March 31, 2015, the link to the electronic survey was sent to 141 fixed-route transit agencies around the U.S. Agencies were given a month (through April 30, 2015) to complete the survey. To ensure a representative sample accounting for diverse geographic, climate, and terrain conditions, the survey covers transit agencies from all 10 regions of the country identified in the Federal Transit Administration's (FTA) National Transit Database (NTD).

In addition to electronic media, agencies were given an option to complete the survey on paper. Paper versions of the survey were e-mailed to the agencies by request. Overall, 48 agencies responded to the survey providing meaningful information for a response rate of $34 \%$. All agencies except one completed the questionnaire online; the remaining agency completed a paper version of the survey.

A summary of findings from the above survey of transit agencies regarding their idle reduction practices is presented in more detail in the following section.

\section{Summary of Survey Results}

Data in this section are based on the 48 fixed-route transit agencies responding to the idle reduction survey. Collectively, the responding 48 agencies have the fleet of 18,258 transit vehicles, representing more than $48 \%$ of the total U.S. fixed-route fleet, as reported by the American Public Transportation Association (APTA) (14). The surveyed fleets vary in size from small agencies with as few as 20 vehicles to large agencies with fleets of more than 5,000 vehicles.

Two-thirds of the surveyed fleets reported employing either technological solutions or policies to reduce idling of vehicles, and one-third reported not having any idle reduction programs in 
place. Figure 1 presents the percentage of agencies using idle reduction technologies or policies vs. agencies without idle reduction programs.

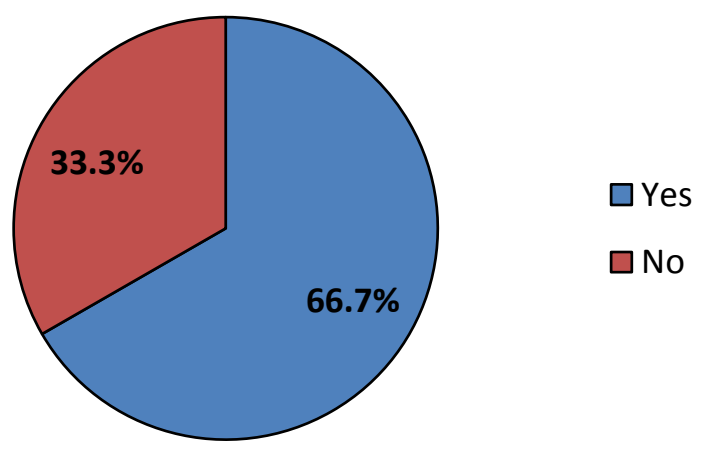

Figure 1 - Transit Agencies with Idle Reduction Programs

More than half of the responding agencies named environmental concerns (i.e., desire to reduce emissions) as the most important factor for implementing idle reduction programs, and $37 \%$ of the respondents viewed fuel cost savings as the strongest motivation for implementing idle reduction. Other reasons for implementing idle reduction technologies included reduction of noise $(2.2 \%)$, reduction of engine wear $(4.3 \%)$, and other factors $(4.3 \%)$ such as compliance with state or local anti-idling regulations and safety issues.

Figure 2 summarizes the responses of the transit agencies regarding the most important factors for implementing idle reduction technologies or policies.

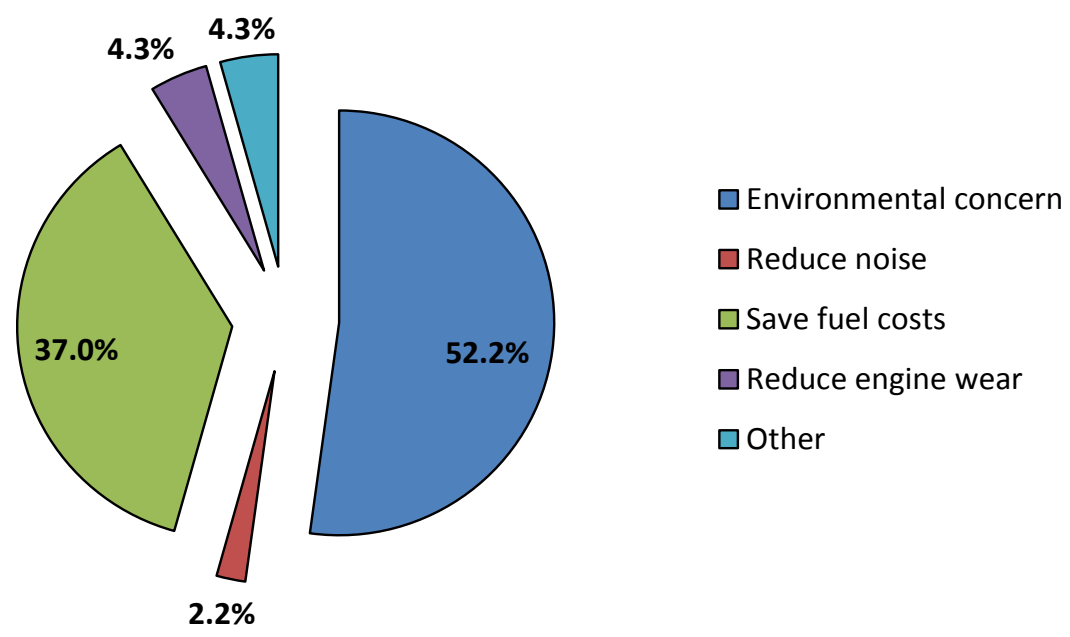

\section{Figure 2 - Most Important Factor for Implementing Idle Reduction Programs}

Saving fuel cost was cited as the second most important factor for implementing idle reduction technologies by $44.4 \%$. Environmental concerns and reduction in engine wear were each 
named by $20.0 \%$ of the responding agencies as the second most important factor for implementing idle reduction technologies or policies. Noise reduction and other factors (including legal requirements and city ordinances) were cited as the second most important factor for implementing idle reduction programs by $8.9 \%$ and $6.7 \%$ of respondents, respectively. The views of the responding agencies about the second most important factor for implementing idle reduction are presented graphically in Figure 3.

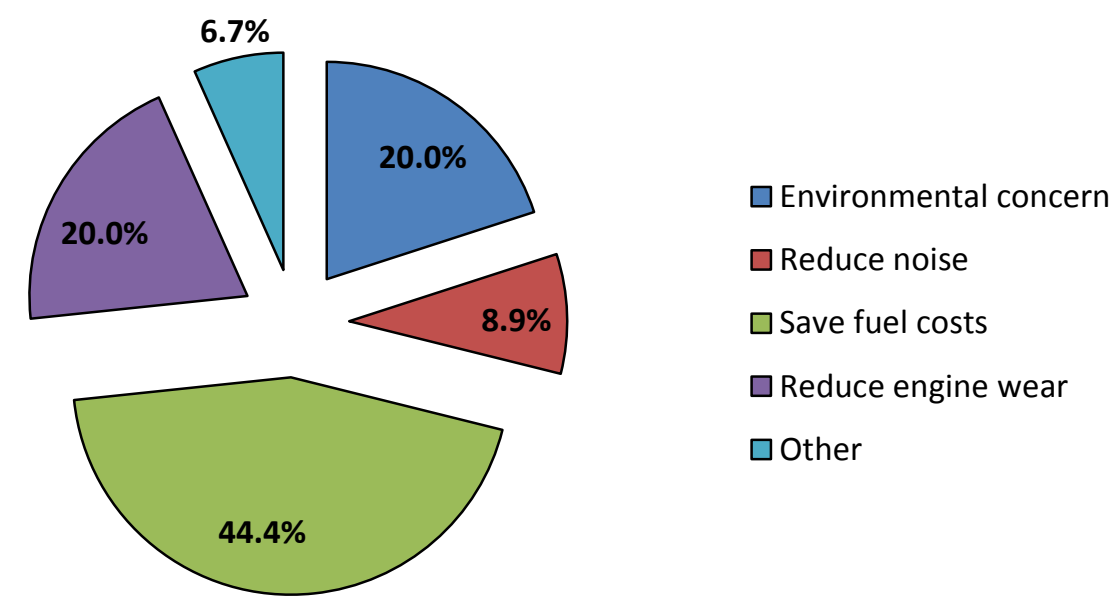

Figure 3 - Second Most Important Factor for Implementing Idle Reduction Programs

The opinions of the surveyed transit agencies regarding the main two motivating factors for implementing idle reduction programs are compared and summarized in Figure 4.

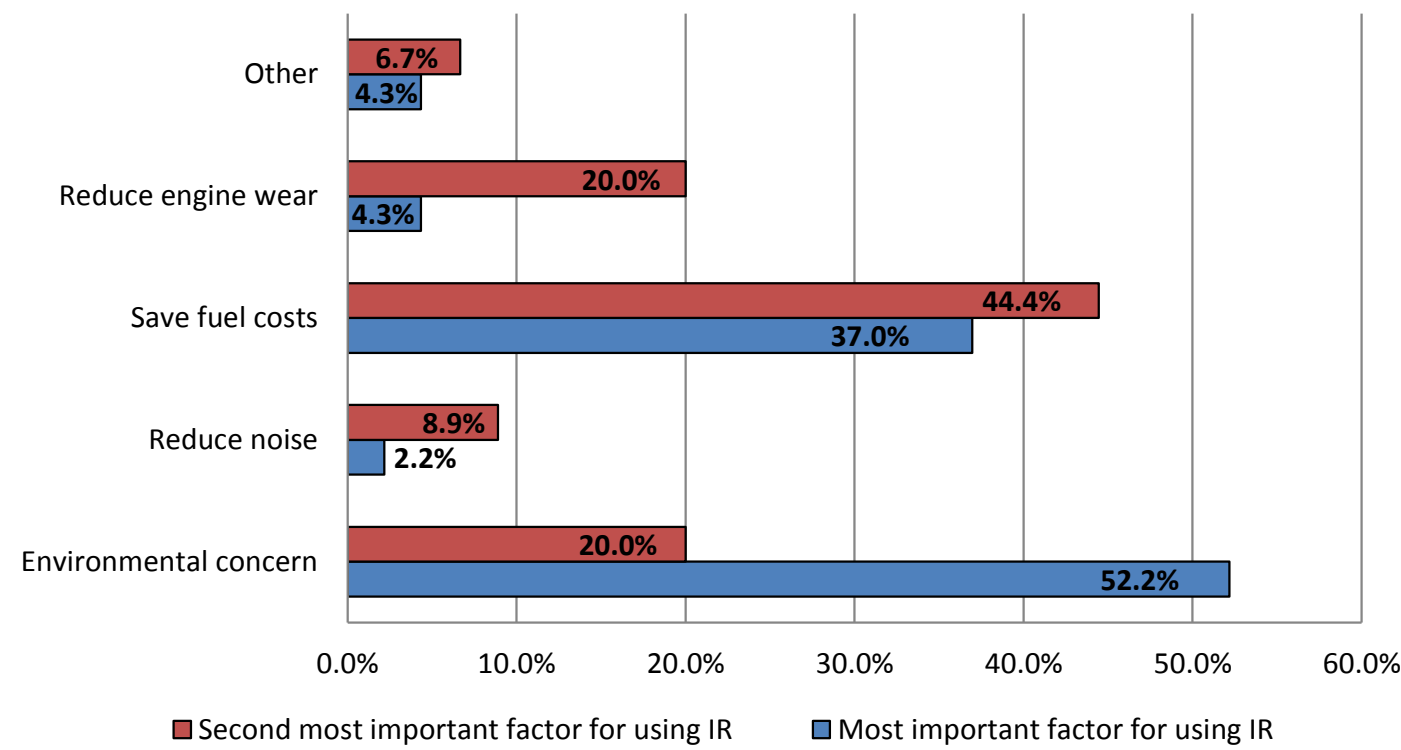

Figure 4 - Comparison of Most and Second Most Important Factors for Implementing Idle Reduction Programs 
Transit agencies were asked to name the most significant obstacles for implementing idle reduction programs. The question did not ask for the naming of specific obstacles encountered by the agency in the process of implementing idle reduction technologies, so the answers received likely reflect perceived obstacles and challenges associated with idle reduction, regardless of whether the agency actually attempted or even considered implementing such technologies in its fleet.

Most of the surveyed agencies (29.2\%) cited the nature of fleet operations as the most significant obstacle for implementing idle reduction technologies, followed by the lack of understanding of the impacts of idling (25.0\%). In addition to these two obstacles, $12.5 \%$ of survey responders cited lack of cooperation from employees, $10.4 \%$ cited lack of legislative incentives, $8.3 \%$ cited lack of knowledge about available technologies, $6.3 \%$ cited cost of idle reduction devices, and $8.3 \%$ cited other factors as the most important obstacles for implementing idle reduction. Other factors were related to weather conditions (either extremely hot or extremely cold) requiring the engine to be kept running for the comfort and safety of passengers.

The responses of the surveyed agencies regarding the most significant obstacle for implementing idle reduction technologies are summarized in Figure 5.

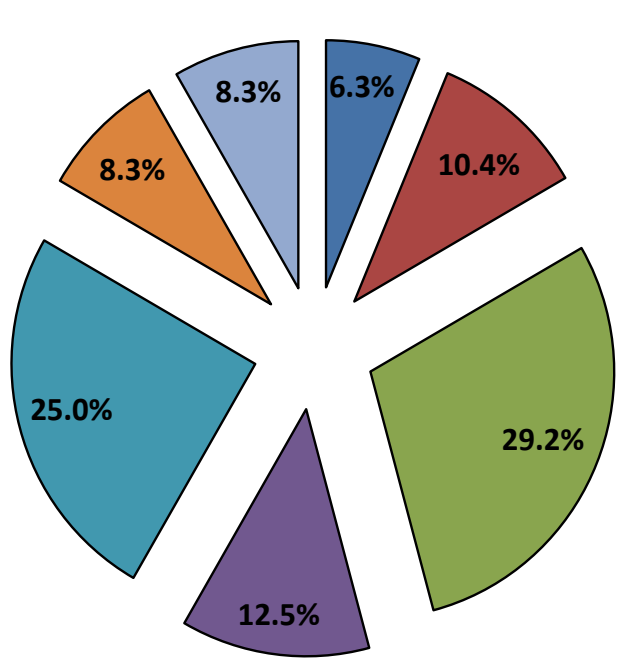

Figure 5 - Most Significant Obstacle for Implementing Idle Reduction Technologies $\square$ Cost of idle reduction devices

$\square$ Lack of legislative incentives

$\square$ Nature of fleet operations

$\square$ Lack of cooperation from employees

$\square$ Lack of understanding of the impact of idling

$\square$ Lack of knowledge about available technologies

口Other

Cost of idle reduction devices and lack of cooperation from employees were the two factors that were cited by the largest number of survey respondents as the second most significant factor for implementing idle reduction technologies. Each of these factors was identified by $21.7 \%$, followed by the lack of understanding of the impact of idling (19.6\%) and nature of fleet operations (15.2\%). Other reasons mentioned include safety and security concerns for drivers and passengers, weather extremes, and maintenance issues (e.g., no starts after 
engine shut-off). The responses of the surveyed agencies regarding the second most significant obstacle for implementing idle reduction technologies are summarized in Figure 6.

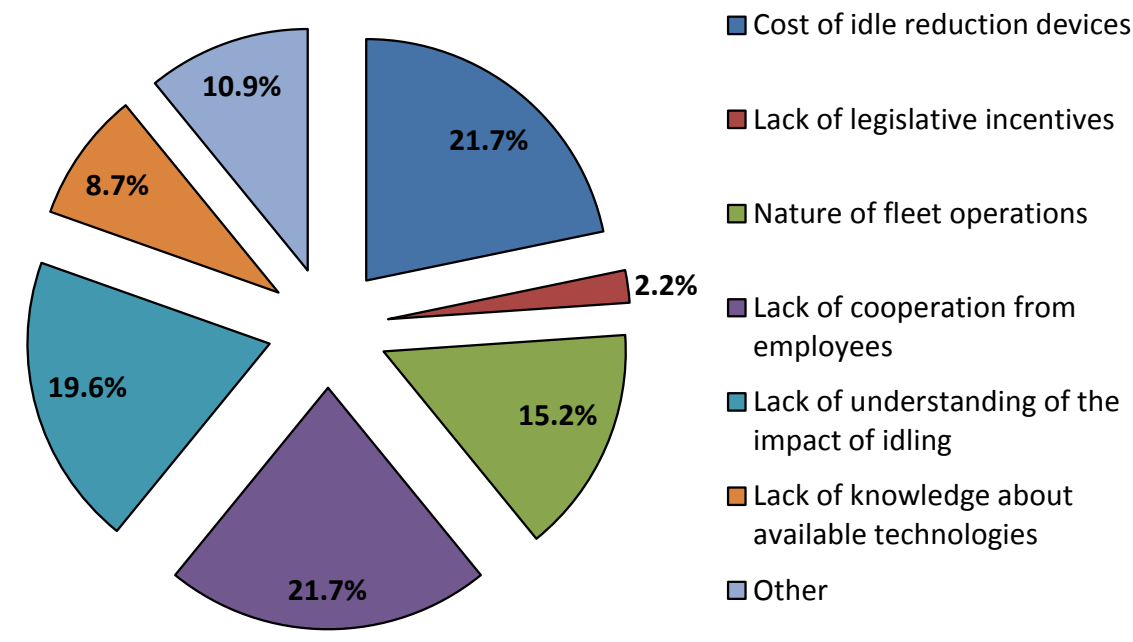

\section{Figure 6 - Second Most Significant Obstacle for Implementing Idle Reduction Technologies}

Figure 7 presents a comparison of the most significant and the second most significant idle reduction obstacles.

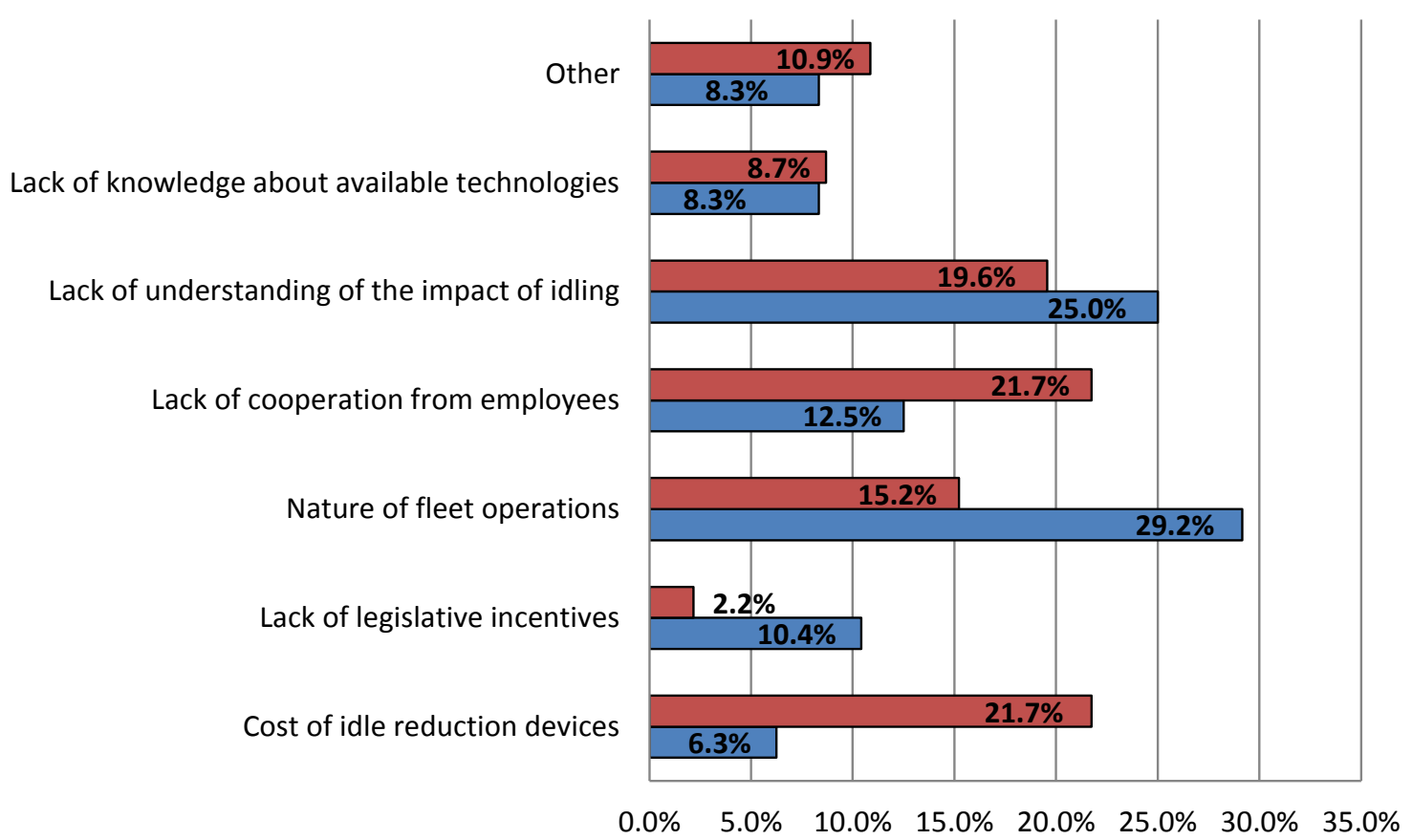

$\square$ Second most significant obstacle for IR $\quad \square$ Most significant obstacle for using IR

Figure 7 - Comparison of Most Significant and Second Most Significant Obstacles for Implementing Idle Reduction Technologies 
The survey asked the agencies to name the types of idle reduction devices used and the number of vehicles on which they are installed. A total of $56.0 \%$ of the respondents reported using some type of idle reduction devices, and $44.0 \%$ indicated that they are not using idle reduction equipment in their fleet.

Automatic engine shut-off is the most popular type of idle reduction technology used by the surveyed fleets, followed by other devices and direct-fired heaters. Almost $35.0 \%$ of the responding fleets use automatic engine shut-off devices, $8.7 \%$ employ direct-fired heaters, and $10.9 \%$ use other devices to reduce idling and lower emissions in general, including fleet management systems, engine depot mode, super capacitors, and alternative fuel vehicles.

Figure 8 summarizes the preferences of the surveyed agencies regarding the types of idle reduction technologies.

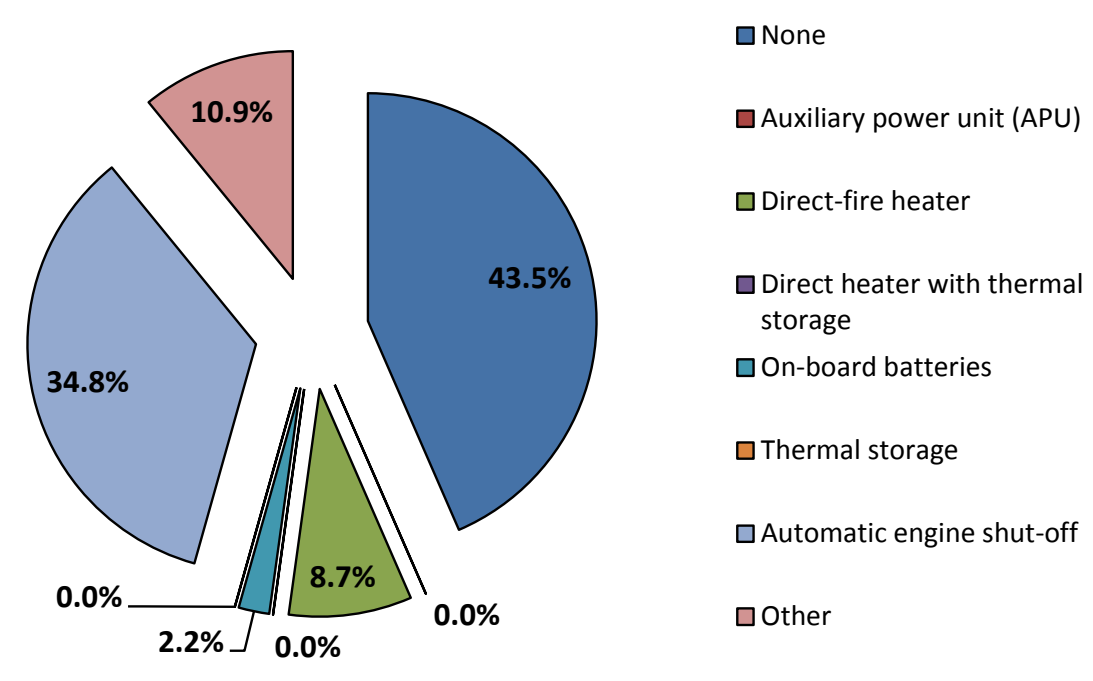

Figure 8 - Types of Idle Reduction Technologies Used

More than $61.0 \%$ of agencies that reported using idle reduction technologies use automatic engine shut-off devices. Direct-fired heaters and other idle reduction devices were used by $15.4 \%$ and $19.2 \%$ of agencies that employ idle reduction technologies, respectively.

Based on the survey data, there are more than 18,000 idle reduction devices of different types installed on U.S. fixed-route transit buses. About $19.2 \%$ of agencies that employ idle reduction technologies reported using more than one type of idle reduction devices in their fleets.

Automatic engine shut-off devices account for $53.3 \%$ of all reported idle reduction devices. Only one agency reported employing on-board batteries to reduce idling. However, due to he large size of that agency, on-board batteries account for more than $30.0 \%$ of all reported idle reduction devices. Direct-fired heaters and other idle reduction equipment (mostly super capacitors) account for $7.2 \%$ and $8.9 \%$ of all reported idle reduction devices, respectively. 
The breakdown of idle reduction devices, by type, installed on transit vehicles is presented in Figure 9.

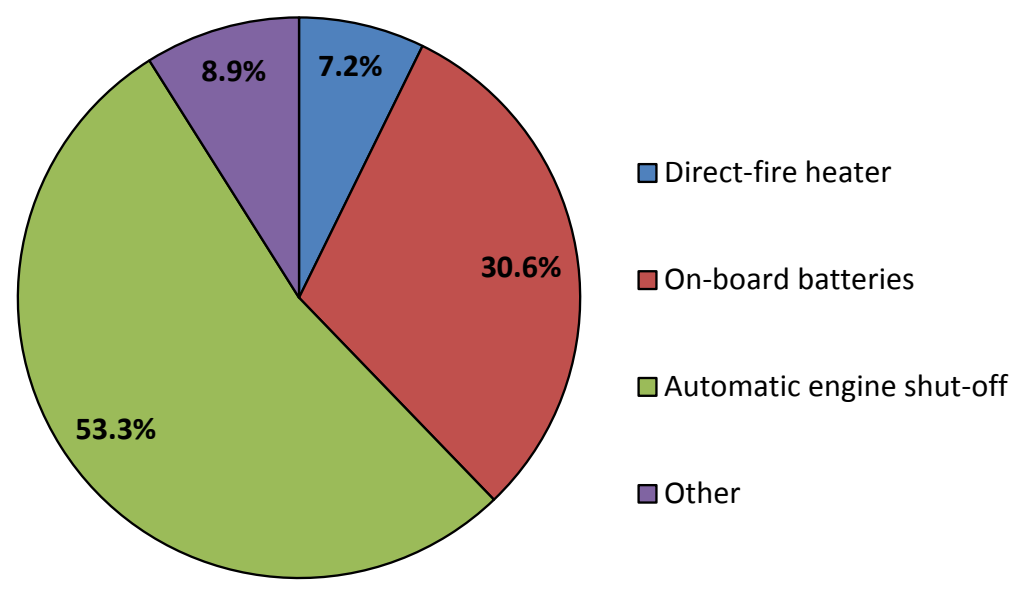

Figure 9 -Idle Reduction Devices Used on Transit Vehicles by Type

Agencies that reported using idle reduction technologies were large, with an average fleet of more than 700 vehicles. This finding is not unexpected. As larger fleets are more likely able to realize significant financial savings from reductions in idling and have the resources to invest in sometimes costly idle reduction equipment.

Agencies that use idle reduction technologies do not necessarily install such devices on their entire fleet. Survey data indicate that the average coverage of fleet by idle reduction technologies varies from $61.6 \%$ to $100 \%$ depending on the type of idle reduction devices. On average, fleets that employ idle reduction have idle reduction devices (of all types) installed on $78.0 \%$ of the vehicles in the fleet. The percentage of fleets covered by different types of idle reduction technologies is presented in Figure 10.

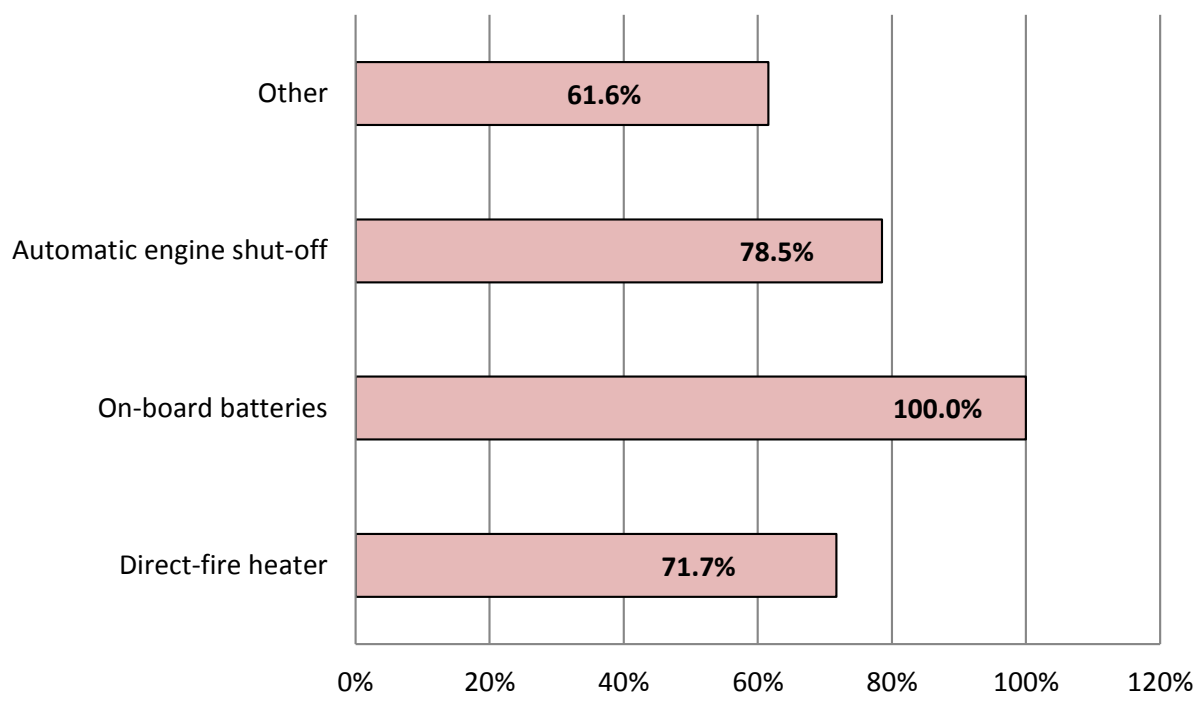

Figure 10 - Fleet Coverage by Type of Idle Reduction Technologies 
The use of different types of idle reduction devices by the transit agencies responding to the survey is summarized in Table 2.

Table 2 - Use of Idle Reduction Technologies by Type

\begin{tabular}{|l|c|c|c|c|}
\hline \multicolumn{1}{|c|}{ IR Technology } & $\begin{array}{c}\text { \# of } \\
\text { Agencies }\end{array}$ & $\begin{array}{c}\text { \# of IR } \\
\text { Devices } \\
\text { Installed }\end{array}$ & $\begin{array}{c}\text { Average } \\
\text { \# of } \\
\text { Buses with IR }\end{array}$ & $\begin{array}{c}\text { Average } \\
\text { \% of } \\
\text { Fleet with IR }\end{array}$ \\
\hline Direct-fired heater & 4 & 1,367 & 342 & $71.7 \%$ \\
\hline On-board batteries & 1 & 5,771 & 5,771 & $100.0 \%$ \\
\hline Automatic engine shut-off & 16 & 10,055 & 670 & $78.5 \%$ \\
\hline Other & 5 & 1,687 & 337 & $61.6 \%$ \\
\hline Total & 26 & 18,880 & 726 & $78.0 \%$ \\
\hline
\end{tabular}

Reduction in idling can be achieved not only by installing specialized equipment on the vehicles, but also through a change in operational procedures. The latter can be achieved through a policy at a rather low incremental cost. Surveyed agencies were asked to provide information about all policies they use (if any) to reduce vehicle idling among the following options: none, shut-down engine after 3-5 minutes of idling, limit engine warm-up (2-5 minutes), minimize vehicle queueing, improve vehicle scheduling and dispatching, and other policies. Agencies could choose all options that applied and also could provide comments and description of other policies used.

The survey data show that a quarter of the surveyed agencies are not using any policy to reduce vehicle idling. More than $40 \%$ of the survey respondents reported deploying more than one idle reduction policy. Shutting down the vehicle engine after 3-5 minutes of idling was the most popular idle reduction policy implemented by the transit agencies, with more than $60.0 \%$ using such a policy. Limiting engine warm-up was the second most popular idle reduction policy, followed by improvements in vehicle queueing and dispatching. These two policies were used by $31.3 \%$ and $20.8 \%$ of the surveyed agencies, respectively.

The preferences of the surveyed transit agencies regarding the type of idle reduction policies are summarized in Figure 11. 


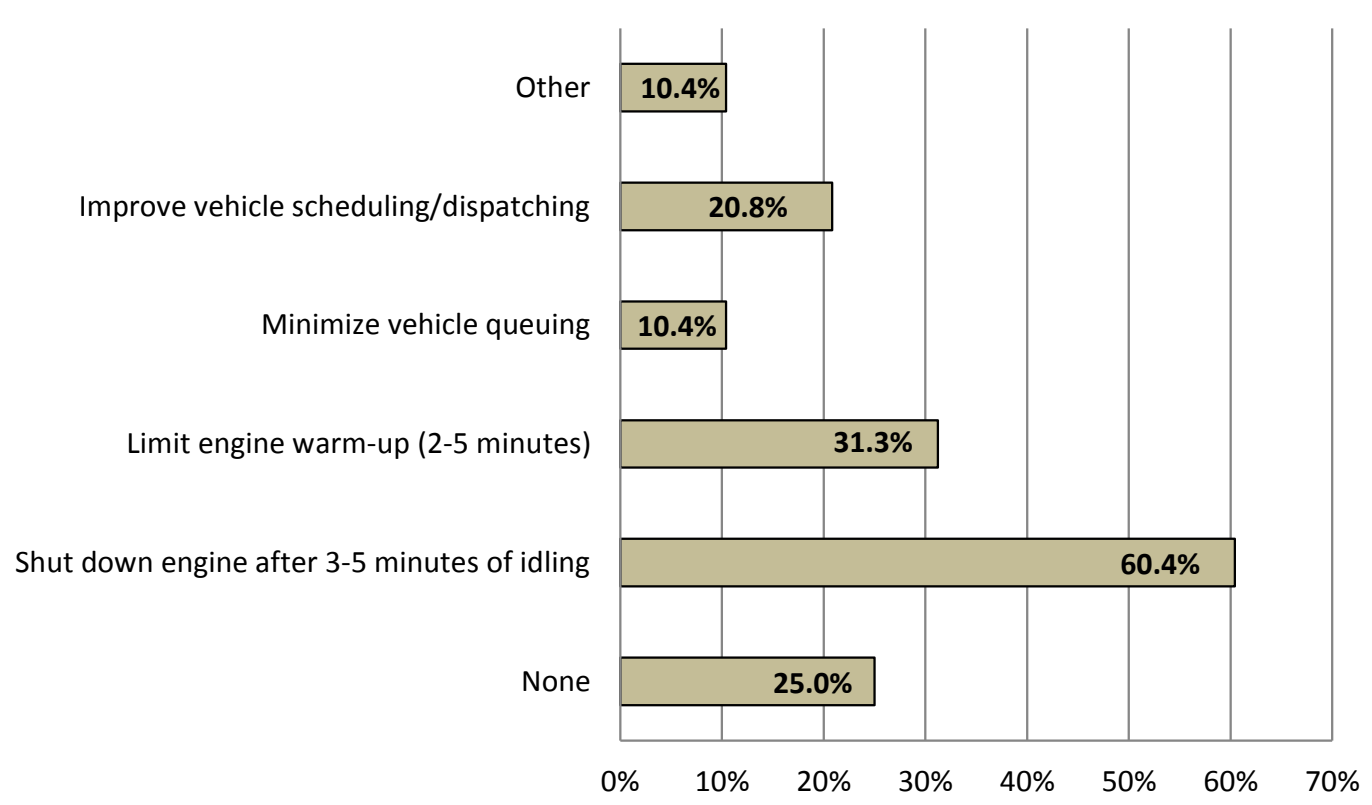

Figure 11 - Idle Reduction Policies Implemented

Other idle reduction policies cited included minimizing idling during vehicle servicing, not allowing unattended vehicle idling, placing information signs at garages and terminals and on vehicle dashboards prompting avoidance of excessive idling, and other policies and procedures.

Almost three-quarters of the surveyed agencies believe that the implemented policies have an effect on the vehicle idle reduction. A total of $20 \%$ of survey respondents believe that idle reduction policies are very effective, and $53.3 \%$ believe they are somewhat effective in achieving the goals of idle reduction. Approximately $4.4 \%$ believe that the listed policies are ineffective in reducing idling, and slightly more than $2.0 \%$ view these idle reduction polices as very ineffective. A total of $20 \%$ of the survey respondents were not sure about the effectiveness of the implemented idle reduction policies.

Opinions of the surveyed agencies regarding the effectiveness of the implemented idle reduction policies are summarized in Figure 12.

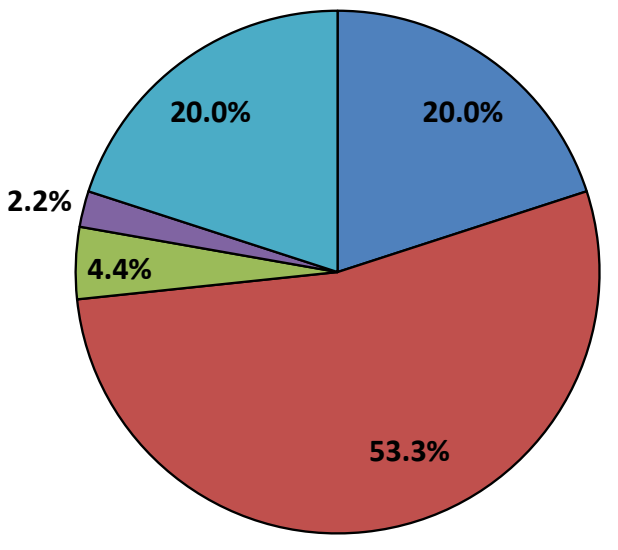

\section{$\square$ Very effective \\ $\square$ Somewhat effective \\ $\square$ Ineffective}

$\square$ Very ineffective

$\square$ Don't know
Figure 12 - Effectiveness of Idle Reduction Policies 
Almost $65 \%$ of the agencies that implement idle reduction technologies or policies do not track the amount of fuel savings resulting from their idle reduction efforts. For agencies that do track the impact of idle reduction, fuel savings range from 5,000 to more than 130,000 diesel gallons per year, for an average annual saving of 39,600 gallons of diesel per agency. Since the reporting agencies vary significantly in the size of their fleets, fuel savings per agency might not be a very meaningful estimate, as it is necessary to take into account agency fleet size to provide a more accurate assessment of the potential impact of idle reduction on fleet's fuel consumption.

Based on the survey data, transit agencies that implemented idle reduction technologies or policies save an average of 165.6 diesel gallon equivalents per year per vehicle. With the current nationwide average price of diesel of $\$ 3.06$ per gallon (15), these fuel savings translate into the reduction of fuel costs of $\$ 507$ per vehicle per year.

A few agencies also reported tracking fuel savings not in exact gallons or gallon equivalents but in more generalized terms (mainly in percentages). The average non-gallon assessment of fuel savings as a result of implementing idle reduction technologies or policies was reported at $5-10 \%$ of total fleet fuel consumption.

In addition to saving fuel cost, two-thirds of the responding agencies also were able to realize other benefits by implementing idle reduction practices. These reported benefits can be categorized in six major categories-environmental benefits (e.g., fewer emissions, cleaner air), compliance with state or local regulations, reduction in engine wear (e.g., fewer breakdowns, increased engine life), improved public perception/approval, noise reduction, and improved driving efficiency and safety.

A total of $20 \%$ of the responding agencies reported reduction in engine wear as an additional benefit of idle reduction practices, followed by environmental benefits (16.7\%), and improved public perception of the agency (13.3\%). Types of additional benefits realized as a result of implementing idle reduction technologies or policies are summarized in Figure 13.

More than half of the agencies that implemented idle reduction in their fleets reported facing various unexpected drawbacks. The most often cited drawbacks from implementing idle reduction technologies and practices include customer and driver complaints about inadequate cabin temperature $(16.7 \%)$, failure of equipment or its improper operation $(13.3 \%)$, difficulty restarting the bus after engine shut-off (10.0\%), and other drawbacks. A challenges also listed by the agencies included non-compliance of employees with idle reduction policies as well as difficulties with enforcement. 


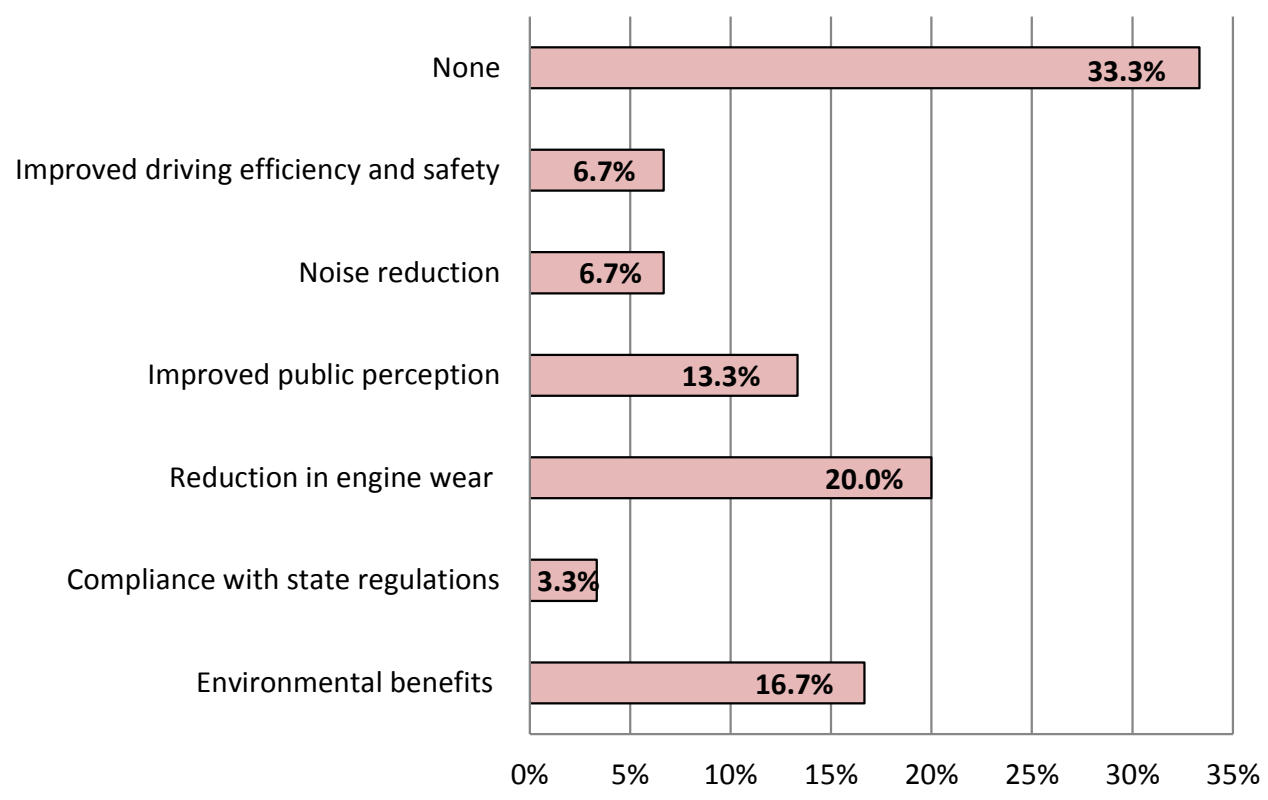

Figure 13 - Additional Benefits of Implementing Idle Reduction Technologies

Common drawbacks associated with implementing idle reduction technologies and policies experienced by the surveyed transit agencies are summarized in Figure 14.

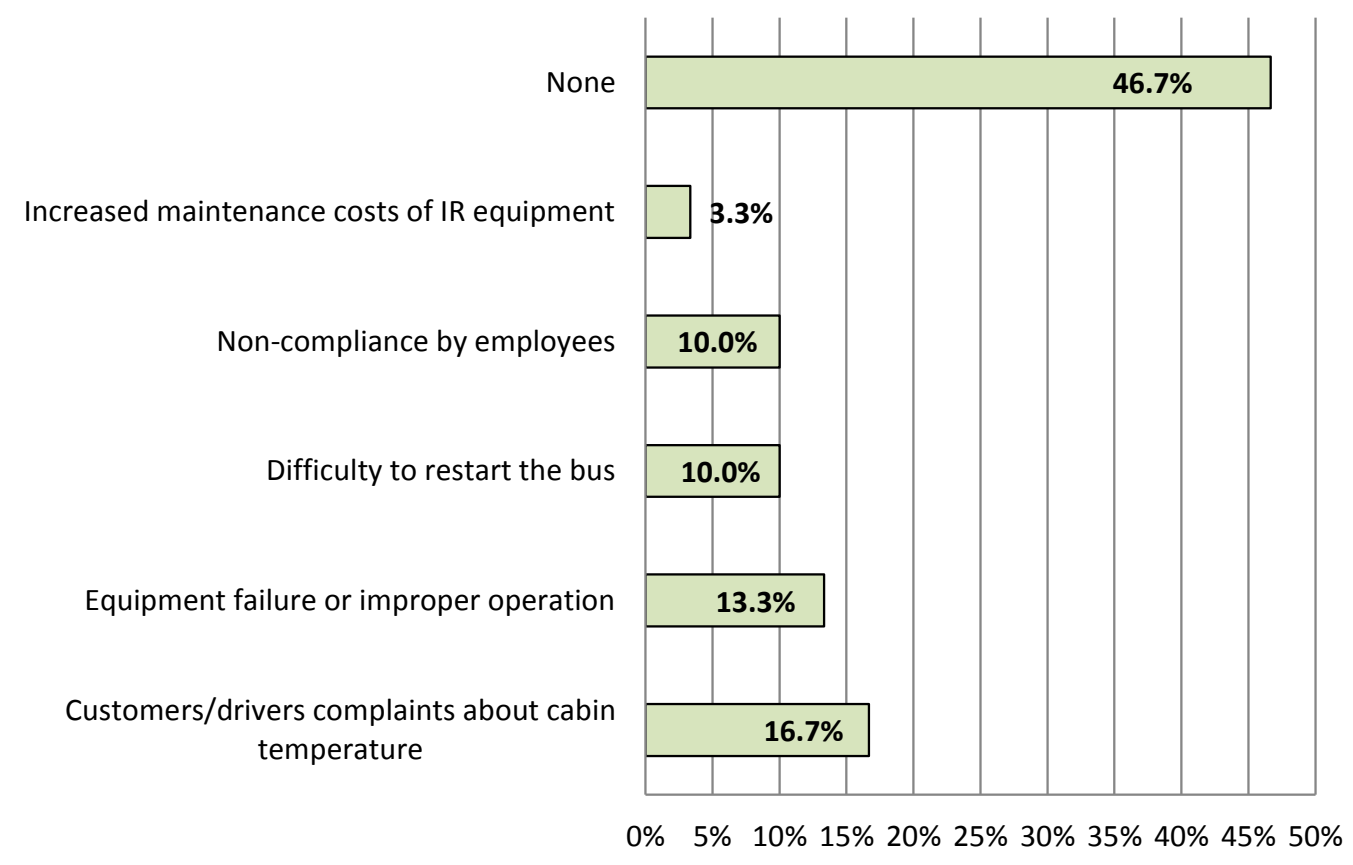

Figure 14 - Unexpected Drawbacks Associated with Idle Reduction Technologies 
The attractiveness of idle reduction programs is affected by the availability of regulatory and financial incentives available to the transit agencies at the state and local levels. Some states and jurisdictions are more active than others in encouraging idle reduction practices.

Only $10.4 \%$ of the surveyed agencies reported that their state or local jurisdiction has regulatory incentives encouraging the use of idle reduction technologies and policies, and more than $52 \%$ reported no such incentives. Additionally, $37.5 \%$ of respondents did not know if their state or local jurisdiction has any regulatory incentive for idle reduction. The responses of the agencies regarding the availability of state or local regulatory idle reduction incentives are presented graphically in Figure 15.

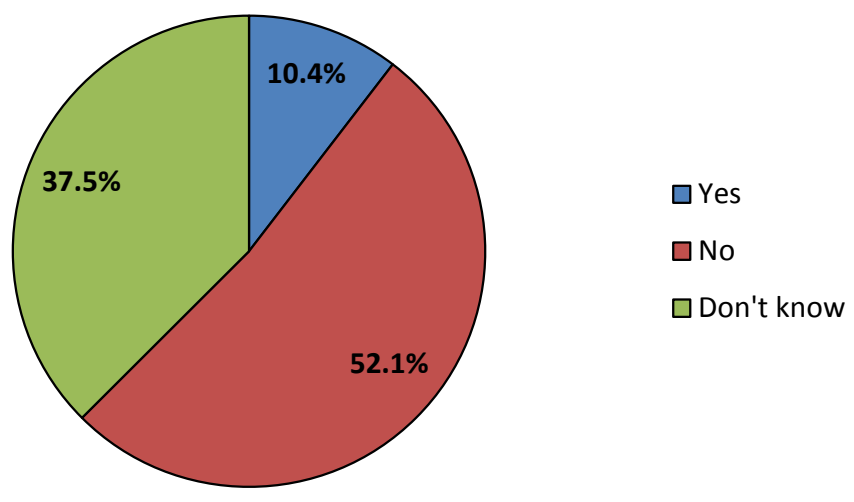

Figure 15 - Availability of State/Local Regulatory Idle Reduction Incentives

Most of the regulatory incentives listed by the responding agencies included some sort of restrictions on excessive idling (i.e., "disincentives"). For the surveyed agencies, local ordinances typically restrict vehicle idling to 5-10 minutes.

Similar to the regulatory incentives, only $10.4 \%$ of the surveyed agencies indicated that their state or local jurisdiction offered financial incentives for idle reduction, and $54.2 \%$ of survey respondents reported no such incentives. Over $35 \%$ of the agencies were not aware if financial incentives encouraging idle reduction were offered in their state or municipality. The responses of the agencies regarding availability of financial incentives encouraging idle reduction at the state or local levels are presented graphically in Figure 16.

Based on the description provided by the agencies that reported having financial incentives at the state or local levels, most of the incentives were in the form of a financial penalty for excessive idling (i.e., "disincentive"). The penalties range from $\$ 250$ to $\$ 500$ for idling restriction violations. Only one agency reported a state program offering monetary grants to reduce emissions from idling vehicles. 


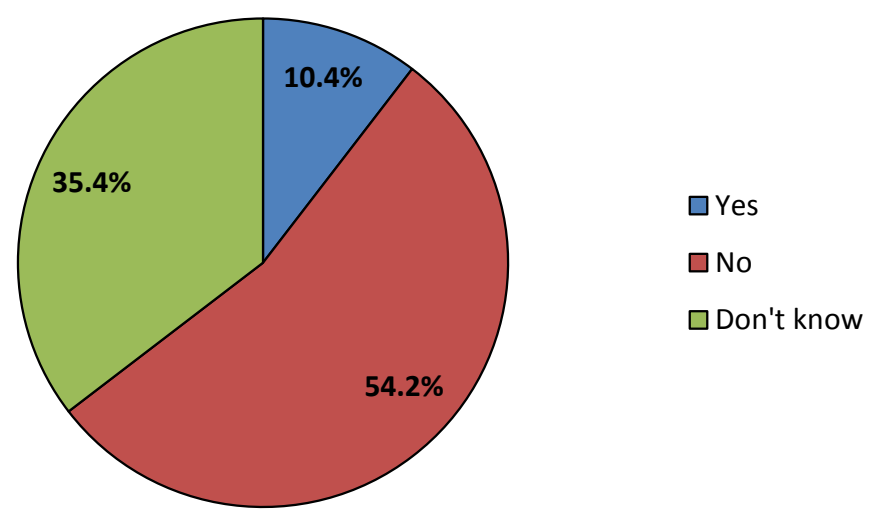

Figure 16 - Availability of State/Local Financial Idle Reduction Incentives

About $20 \%$ of respondents believe that the existing incentives are effective in reducing vehicle idling. Approximately $2.2 \%$ view the incentives as very effective, and $17.8 \%$ find the existing incentives somewhat effective. At the same time, $6.7 \%$ believe the existing incentives are very ineffective in reducing vehicle idling, and almost two-thirds did not know how effective state and local idle reduction incentives are.

Opinions of the responding agencies regarding the effectiveness of the existing state and local idle reduction incentives are summarized in Figure 17.

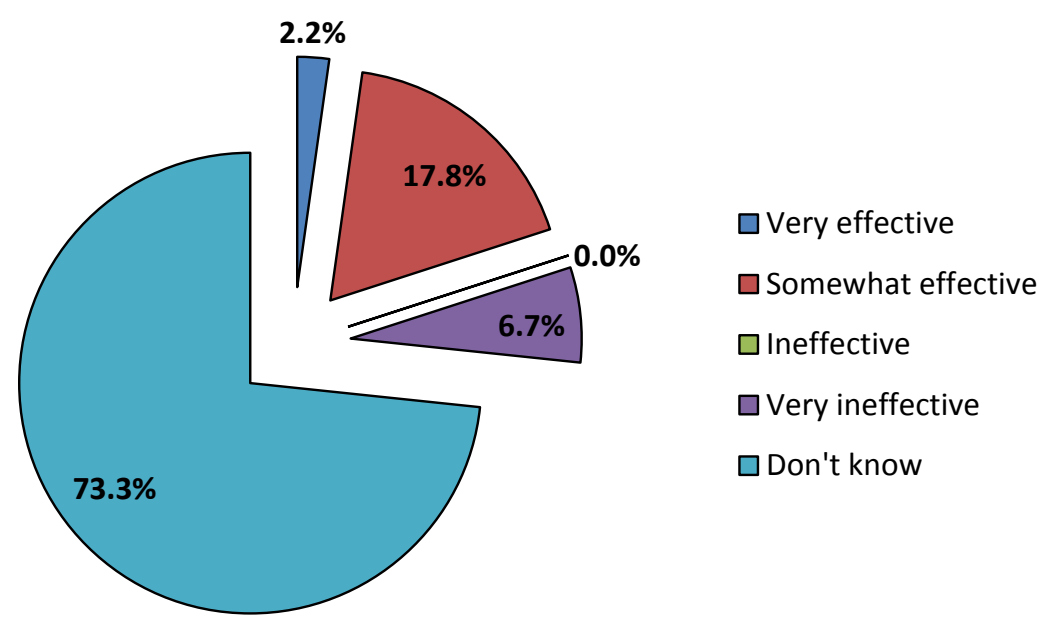

Figure 17 - Perceived Effectiveness of State/Local Idle Reduction Incentives

It should be noted that the responses of transit agencies regarding the availability of various idle reduction incentives do not necessarily show the real state of idle reduction programs at the state and local level. The responses reflect only the opinions of the agencies regarding idle reduction incentives in their states and municipalities. It is likely that such opinions may be faulty due to the lack of information about idle reduction programs. 
Finally, the fact that a large percentage of respondents did not know if their state or local jurisdiction offered any idle reduction incentives indicates the lack of knowledge on the part of transit agencies. Educating fixed-route transit agencies about the availability of state and local idle reduction incentives may be useful for encouraging wider adoption of idle reduction practices. 


\section{Chapter 5 \\ Idle Reduction Incentives}

To promote fuel conservation and encourage more environmentally-friendly behavior, both the federal government and state officials around the U.S. have established various incentives aiming to reduce the consumption of fossil fuels and curb harmful emissions. Many such incentives focus on the transportation sector, especially on large commercial fleets.

The goal of any government incentive is to encourage the activity viewed as desirable by state or local officials. Some state and local jurisdictions are more active than others in promoting such activities. The goal of idle reduction incentives is to reduce unnecessary idling of vehicles, leading to lowering consumption of fossil fuels and decreasing harmful tailpipe emissions.

All incentives (including idle reduction incentives) may vary by type, form, and application. The U.S. Department of Energy (DOE) website lists six broad categories of incentives that exist in various states, including grants, tax incentives, loans and leases, rebates, exemptions, and other forms of incentives (16). The type of the incentive describes the form of the enticement used to incentivize certain activities. Although there is a large number of common incentive types in use, all can be grouped into two major categories: regulatory incentives and financial incentives.

Regulatory incentives include different regulatory measures, such as various restrictions and exemptions, making the use of idle reduction attractive or convenient. Financial incentives provide financial benefit for the use of idle reduction technologies and policies through various grants, loans, discounts, credits, refunds, rebates, and other financial encouragement.

Whereas both types of incentives can help achieve desired results, anecdotal evidence suggests that financial incentives are more likely to be successful in achieving the intended goals, provided they are large enough to entice intended behavior. As a general rule, successful financial incentives should be large enough to offset much of the incremental cost associated with the encouraged activity (e.g., idle reduction). Even potential tangible benefits of idle reduction technologies such as reduction in operating and maintenance costs may not always be sufficient to convince fleets to pay higher up-front costs.

Additionally, it is commonly believed that incentives that come in the form of direct grants or rebates are the most effective form of incentives. Previous research found that consumers more readily take advantage of grant and rebate programs than tax-based incentives, and the findings indicate a clear preference for this incentive type. Grants offer immediate benefits and certainty, since customers know how much the grant or rebate is worth. They are also attractive to small companies (with small tax liabilities) and non-taxable entities, such as municipal governments or non-profit organizations. Therefore, to be successful, idle reduction incentives need to be grant-based, i.e., they should be in the form of a direct grant or a rebate.

There are a total of 106 laws, regulations, programs, and incentives dealing with idle reduction at the federal and state levels. At the federal level, there is one idle reduction equipment tax 
incentive, one law allowing states to provide weight exemption for idle reduction equipment, and five programs encouraging activities reducing fuel consumption (including idle reduction efforts).

At the state level, there are 55 incentives, 43 laws and regulations, and 1 fleet assistance program. Overall, 41 states and the District of Columbia have some kind of incentive or law addressing idle reduction. In total, 28 of the state incentives provide weight exemption for the vehicles with idle reduction equipment, allowing them to exceed state's maximum weight rating (gross or per axle) by $400-550$ pounds (depending on the state). Accounting for over $50 \%$ of all state incentives, weight exemption is, by far, the most popular type of state incentive. Of the remaining incentives at the state level, 15 incentives (27.3\% of all incentives) are grants, $5(9.0 \%)$ are loans, $4(7.3 \%)$ are tax credits or exemptions, and $3(5.5 \%)$ are either rebates or reimbursements. Types of state and federal idle reduction laws and incentives are summarized in Table 3.

Table 3 - Types of Idle Reduction Laws and Incentives

\begin{tabular}{|l|l|c|}
\hline \multicolumn{1}{|c|}{ Category } & \multicolumn{1}{c|}{ Type of Incentive/Law } & \multicolumn{1}{c|}{$\begin{array}{c}\text { Number of } \\
\text { Laws/Incentives }\end{array}$} \\
\hline \multirow{2}{*}{ Laws and Regulations } & Weight Exemption & 1 \\
\hline \multirow{2}{*}{ Incentives } & Tax Exemption & 1 \\
\cline { 2 - 3 } & Emission Reduction Program & 5 \\
\hline \multirow{5}{*}{ Laws and Regulations } & 33 \\
\hline \multirow{5}{*}{ Incentives } & Idle Reduction Restrictions & 6 \\
\cline { 2 - 3 } & Sustainability/Energy Plan & 2 \\
\cline { 2 - 3 } & Fleet Management \& Emission Control & 2 \\
\cline { 2 - 3 } & Other & 28 \\
\hline & Weight Exemption & 15 \\
\cline { 2 - 3 } & Grant & 5 \\
\cline { 2 - 3 } & Loan & 4 \\
\cline { 2 - 3 } & Tax Credit or Exemption & 3 \\
\cline { 2 - 3 } & Rebate or Reimbursement & 1 \\
\hline
\end{tabular}

The most comprehensive incentives at the federal level are represented by various national programs aiming to decrease the consumption of fossil fuels and reduce greenhouse gas (GHG) emissions. Programs such as the Congestion Mitigation and Air Quality (CMAQ) Improvement Program, Clean Cities, Clean School Bus USA, and others provide funding and encourage public-private collaborations to adopt new technologies and practices (including alternative fuel technologies and idle reduction) allowing to reduce petroleum use and lower harmful emissions from the transportation sector.

State incentives are represented by a combination of regulatory and financial incentives. Explicit restrictions on the amount of idling of heavy-duty vehicles account for $33.7 \%$ of all state idle reduction incentives/regulations, and financial incentives such as direct grants, rebates, loans, tax credits, and exemptions account for $27.6 \%$ of all state incentives. Considering that 
idle reduction equipment can be rather costly, financial incentives may be more effective than administrative measures in encouraging significant reduction in vehicle idling.

California's Carl Moyer Air Quality Standards Attainment Program and Heavy-Duty Vehicle Emissions Reduction grants provide funding to cover the incremental cost of installing on-board idle reduction equipment and truck stop electrification and retrofit. The Clean Diesel Across Indiana program provides grants to bus fleets of up to $\$ 75,000$ for projects reducing diesel emissions, including retrofitting vehicles with idle reduction equipment. Idle Reduction Technology grants in Maryland provide grants to motor carriers operating Class 6 and Class 8 trucks in the state to cover $50 \%$ of incremental cost, up to $\$ 3,500$, of idle reduction technologies. The Small Business Advantage Grant Program in Pennsylvania provides matching grants of $50 \%$, up to $\$ 9,500$, to small businesses to acquire pollution prevention equipment, including idle reduction devices. These are just few examples of successful grant-based idle reduction incentive programs around the U.S. A more detailed summary of all federal and state idle reduction incentives is provided in Appendix $\mathrm{C}$.

In addition to federal and state regulations, there is also a variety of local idle reduction laws and incentives supporting reduction in petroleum consumption and tailpipe emissions. Just as with federal and state regulations, local regulations typically impose specific limitations for the amount of time heavy-duty vehicles are allowed to idle their engines in the city. Similar restrictions are also typical for school buses. Local incentives may range from grants to rebates, loans, and to other types of assistance to the agencies deciding to adopt idle reduction practices.

The U.S. Department of Energy's National Clean Cities Program reported that, in 2013, idle reduction efforts throughout the country displaced a total of 29.5 million gasoline gallon equivalents. Idle reduction equipment installed on board vehicles is responsible for $46.0 \%$ of that petroleum reduction; $43.7 \%$ of the petroleum displacement was achieved through various idle reduction policies, and truck stop electrification accounted for $10.2 \%$ of the total petroleum GGEs displaced (17).

The numbers show that idle reduction policies displace practically the same amount of petroleum as idle reduction equipment, demonstrating that agencies do not necessarily have to spend significant amounts of money to take advantage of idle reduction practices. Idle reduction policies may be implemented with little or no cost to the agencies and can provide tangible benefits in terms or fuel cost savings.

Idle reduction has seen tremendous growth in the past decade. From 2003 through 2013, the annual amount of petroleum displaced by various idle reduction technologies and policies increased by $145.8 \%$. The largest growth was in the use of on-board idle reduction devices. The amount of petroleum displaced annually by on-board idle reduction technologies has grown by more than 27 times since 2004. For comparison, the amount of GGEs displaced annually by idle reduction policies increased by $45 \%$, and the amount of petroleum displaced annually as a result of truck stop electrification increased by $16 \%$ over the same period (17). 
Petroleum displacement resulting from the use of idle reduction technologies and policies, as reported by the DOE's Clean Cities program, is summarized in Figure 18.

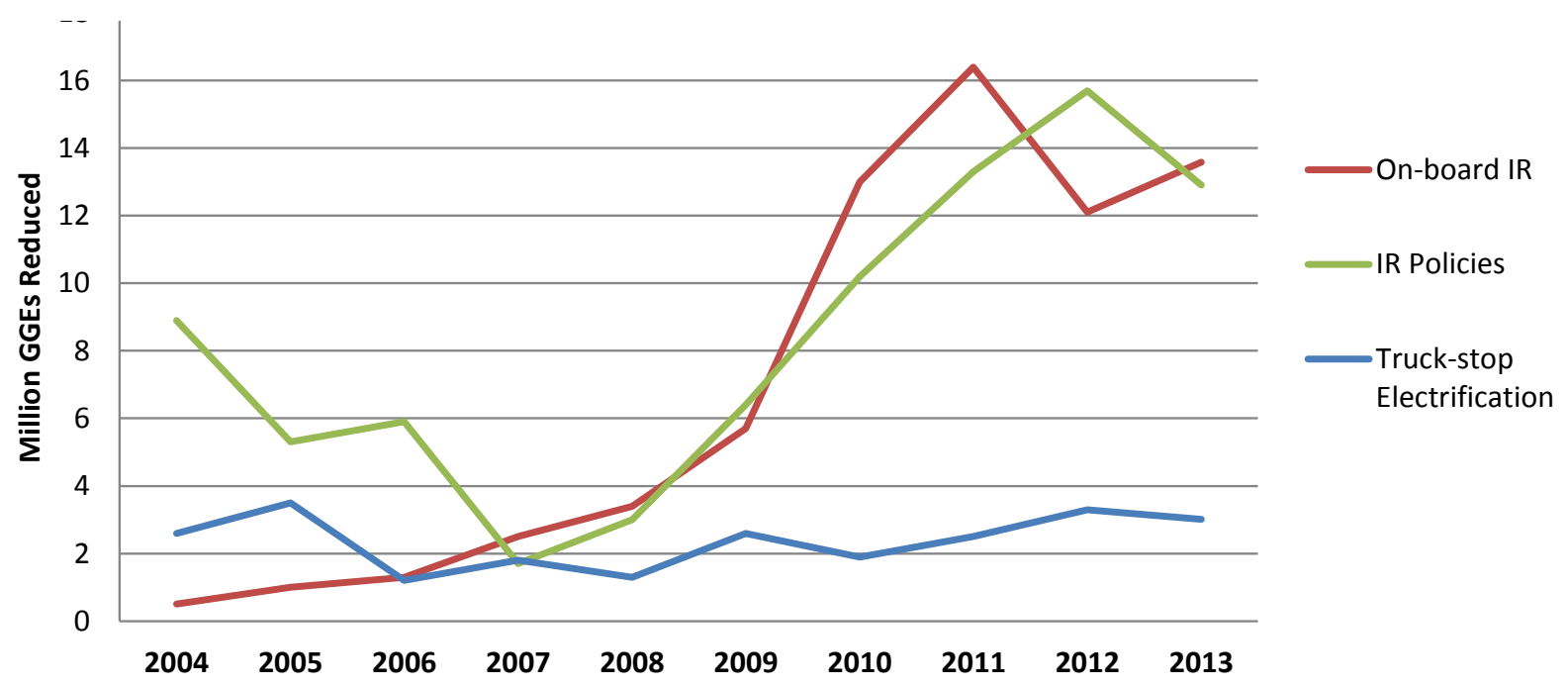

Figure 18 - Petroleum Displacement by Idle Reduction 


\section{Chapter 6 \\ Best Practices in Idle Reduction}

Any incentive is designed to change established behavior and motivate individuals and organizations to perform actions producing public benefits. There are multiple factors, both objective and subjective, that may contribute to the success or failure of each individual incentive. The design of an idle reduction incentive program is one of the key factors in achieving desired reductions in vehicle idling and the resulting reductions in fuel consumption and emissions.

Previous research and anecdotal evidence indicate that to be successful, idle reduction incentives need to have the following characteristics:

- focused on specific goals

- incentive amount is large enough

- grant-based

- enforceable

- not only restrict/prohibit but also provide an alternative

- involve employees

\section{Focused on Specific Goals}

The goals of the incentive program should be clearly identified and spelled out. This is the best way to meet these goals. The main goals of idle reduction programs are to reduce fuel consumption and vehicle emissions. A proper incentive program should be designed with fuel conservation and emission reduction in mind, recognizing that reduction in vehicle idling is one of the methods of achieving that goal.

\section{Incentive Amount Is Large Enough}

A good incentive should be large enough to cover most of the incremental cost of idle reduction equipment retrofit. Even potential tangible benefits of using idle reduction technologies, such as fuel savings and reduction in vehicle maintenance costs, may not always be enough to convince users to encounter higher up-front costs. Incentives that yield insignificant savings or savings that are realized in distant future typically fail to change the behavior of vehicle owners and operators.

At the same time, government officials should also avoid incentives that are too large. There is rarely a good reason to offer an incentive that covers more than the incremental cost of the new technology.

\section{Grant-based}

Most efficient financial incentives often come in the form of grants or rebates. Previous research has found that consumers more readily take advantage of grant and rebate programs than taxbased incentives. Unlike tax-based incentives, grants offer immediate benefits and certainty, 
since customers know how much the grant or rebate is worth, and they are also more attractive to non-taxable entities, such as municipal governments or non-profit organizations.

\section{Enforceable}

To be effective, any regulatory restriction needs to be enforceable. Any restriction should provide the procedure for monitoring compliance and suggest feasible method of penalizing the violators. Many idle reduction restrictions imposed by local jurisdictions around the country lack realistic enforcement procedures. Although many states and municipalities impose fines for idling over the specified amount of time, in reality, most such idle restrictions rely on selfcompliance.

\section{Not Only Restrict/Prohibit, but Provide an Alternative}

A good incentive should not only restrict certain activities (e.g., idling) but also provide an alternative. Many states and cities enacted laws that restrict idling of diesel vehicles to a certain maximum amount of time (typically 5-15 minutes). However, very rarely, secure parking areas with appropriate locations where vehicle operators (particularly bus operators) can wait are available. This is particularly relevant to coach buses, which often have to wait for hours with their bus for passengers to return from a visit to a tourist destination.

To avoid inti-idling penalties, some coach buses chose to circulate in traffic instead of stationary idling. Urban traffic simulation results demonstrate that motor coach buses circulating in traffic produce more NOx and consume at least twice as much fuel, compared to stationary idling (18). Thus, if vehicle operators chose to circulate in traffic, the imposed idle restriction laws are, in fact, producing the opposite effect of what they were intended to do. Providing parking facilities with lounges in which bus operators can wait, together with the restriction of idling, will likely be more effective in reducing fuel consumption and emissions than idling restriction alone.

\section{Involve Employees}

Employee cooperation is crucial to the success of any idle reduction program. Organizations that are serious about idle reduction spend much time informing employees about the goals of the program and educating them about the impacts of idling. Lack of cooperation from employees is one of the common reasons why idle reduction programs fail to achieve desired goals.

In a study of truck drivers, it was found that habit and myths often play a large role. If drivers have never been told to shut off their engines when loading or unloading passengers, they will not do it on their own. Long-haul truck drivers were taught not to turn off a diesel engine for the fear it would not restart. Although it may be the case with some older engines, this is not necessary with modern engines. Also, many people erroneously believe that restarting a hot engine emits more pollution than idling (11).

If drivers decide not to follow idle reduction instructions and policies, they can ignore idle reduction rules and bypass idle reduction devices installed on-board (e.g., restart the engine manually immediately after it was shut down by automatic shut-off device). Educating drivers 
and other employees should help address those issues and ensure successful implementation of idle reduction policies.

A good practice is to provide incentives to employees for abiding by the idle reduction policies and to encourage competition among employees. For example, a fleet may track fuel savings by each driver, rank drivers by their fuel economy performance and reward drivers that demonstrate highest fuel economy.

\section{Case Studies}

The following section provides a few select examples of successful and unsuccessful application of idle reduction technologies and policies.

\section{Petroleum Reduction at Braun's Express Fleet - Massachusetts (19)}

Braun's Express is a long-haul trucking company with a total fleet of 400 vehicles. Since 2004, the fleet has implemented a variety of technologies and strategies, including idle reduction, hybrid electric vehicles (HEVs), telematics, and driver training. These strategies have increased overall fuel economy by an estimated 1 mile per gallon (MPG) across Braun's 185 tractor fleet. This equates to 1,500 gallons of fuel and $\$ 6,000$ saved per truck per year and more than 10,700 tons of carbon dioxide $\left(\mathrm{CO}_{2}\right)$ emissions avoided annually across the fleet.

Headquartered in Hopedale, Massachusetts, Braun's operates up and down the U.S. East Coast. One of Braun's primary trucking routes is between its Georgia and Massachusetts warehouses. Along the way, the company has four terminals where drivers can stop to load and unload products and satisfy their mandatory rest periods. The 60 sleeper-cab trucks that travel along this route are equipped with IdleFree battery-powered APUs, which allow drivers to have heated and cooled air and other comforts, such as electricity for laptop computers, without running the vehicle's engine.

For power, the trucks can plug in to electrified parking spaces (EPS) installed at the company's terminals and one additional rest stop along the route. According to data Braun's has collected, the APUs improve overall fuel economy from 5.87 MPG to $6.75 \mathrm{mpg}$ and have a payback period of less than one year. In addition, the promise of added comfort in the cab helps the company recruit and retain top drivers.

The fleet installed the electronic systems in two trucks allowing to extend the life of batterypowered APUs. Braun's then installed proprietary solar equipment on the same two trailers' roof fairings to provide additional auxiliary power. The company estimates that the energy collected by the solar technology alone provides air conditioning for six to eight hours, depending on the weather. All 185 of the fleet's tractors are also equipped with automatic shutdown technology to prevent the vehicles from idling for long periods.

Given Braun's significant investment in fuel-efficient technologies, it was important for the fleet team to be able to track improvements and ensure that driver behavior changes complement the technology. The driver and vehicle evaluation tool used by the company for this purpose 
tracks overall fuel economy, speed, and idle times. The result is a scorecard that ranks drivers by their fuel economy performance. Braun's is committed to using onboard computers to collect data from the vehicles and factor in all costs to make sure the real return on investment can be demonstrated.

Braun's makes the information provided through telematics available to drivers, showing each how they compare to their peers. This data helps motivate drivers to be more efficient. The fleet also holds periodic driver training and plans to increase the frequency of these trainings in the future. Braun's also plans to roll out a fuel economy bonus program for its drivers.

\section{St. Louis County School Buses Idle Reduction - Missouri (20)}

In 2009, Special School District of St. Louis County (SSD) received Missouri Air Pollution Program clean diesel grant to address diesel emissions produced by school buses. The EPA grant allowed SSD to install Espar fuel-operated heaters on 21 buses. The heaters use a small amount of diesel fuel to warm the coolant lines of the vehicles while the bus engine remains off.

The heaters activate automatically when temperatures drop below 60 degrees, so technicians do not need to start and then idle the bus engines on cold mornings and afternoons. By the time drivers pick up their first students, the buses are comfortable. The heaters are programmable, so they do not run on weekends or holidays unless needed.

In addition to reducing emissions, the heaters save at least 3 gallons of diesel fuel per bus per day. The initial success paved the way for expansion of the program adding more heaters in 2010 and 2011 at a cost of $\$ 1,364$ per heater. By the end of 2011,116 buses-virtually the entire SSD fleet-had been equipped. Since then, this program has been repeated in about a dozen other school districts in Missouri covering 600 school buses.

\section{School Buses Go Green - Virginia (21)}

Four counties in Virginia used multiple funding opportunities available from the U.S. EPA's Clean School Bus USA program, the Virginia Department of Environmental Quality (VDEQ), the Mid-Atlantic Regional Air Management Association, and other sources to deploy bio-diesel, idle reduction, propane, and other emission-reduction strategies over the period from March 2008 through December 2010.

School districts in four counties used $\$ 39,000$ to install diesel oxidation catalysts on 70 buses to reduce diesel emissions. It is estimated that these devices averted at least 39 tons of emissions during the 32-month project period, and they continue to contribute to improved air quality today. The project also paid up to $\$ 0.06$ per gallon toward the use of B5 (5\% biodiesel, $95 \%$ petroleum diesel) by two school districts.

Districts in two counties installed 24 engine block heaters and conducted driver training to reduce idling time by $23 \%$, resulting in total estimated emissions reductions of more than 5 tons per school year. 
A pilot project in Gloucester County Public Schools put five Blue Bird propane school buses on the road. Funds from EPA and VDEQ subsidized the incremental cost of purchasing the buses, and now the district is benefitting from lower emissions, reduced petroleum use, lower fuel costs, quieter operation, and higher driver satisfaction. From October 2009 to November 2010 , the five buses saved almost $\$ 7,000$ in fuel and maintenance costs and averted 8.4 tons of GHG emissions.

\section{Walled Lake Consolidated School District Idle Reduction - Michigan (22)}

Walled Lake Consolidated School District (WLCSD) operates 119 diesel buses of various size, make, and model, covering 107 different routes and transporting 12,000 school children. In 2007, the school district implemented a competition among drivers to increase fuel economy and lower overall fuel costs through idle reduction practices. Two drivers with the greatest increase in miles per gallon through reduction in idling would be rewarded with a parking space in a bus garage. Parking in a garage was viewed as a significant incentive since the winners would not have to warm up their buses, clean off snow in the winter or walk long distance from the facility to the parking area. To be fair, the competition was performed separately in two groups: the general education buses and the special education buses, since the latter buses typically have to idle longer due to special need of children (such as loading wheelchairs).

To properly monitor the fuel economy and idling practices, all the buses were equipped with management and maintenance software, allowing to track mileage, calculate fuel usage and generate reports to mechanics and maintenance director. Before the competition was announced, engine running time, actual miles driven, and miles per gallon for each bus were monitored during two months to establish a baseline for each driver and bus. During this twomonth monitoring period, the typical idling range was estimated to average $20 \%$ and the average fuel consumption rate was 7 miles per gallon. After two years of "competition," average idling rates dropped below $10 \%$ and the average fuel mileage for the fleet increased to 7.5 miles per gallon. It is estimated that the change in driver behavior due to this idle reduction initiative saved the district $\$ 28,000$.

In addition to changing driver behavior, the district also installed auxiliary heaters on more than half of the school bus fleet, allowing to heat up engine coolant, eliminate cold starts and reduce idling warm up.

One added benefit of the monitoring system is the ability to perform preventive maintenance on the vehicles more efficiently. If a bus shows a drastic decrease in efficiency this signals to the maintenance department that something might be wrong with the bus. The mechanics would perform tests to determine if the change in fuel efficiency happened due to increased idle time or a mechanical failure of vehicle components. 


\section{Chapter 7 \\ Conclusions}

Unnecessary idling wastes fuel and produces harmful emissions that contribute to global climate change and cause public health concerns. Heavy-duty vehicles may idle for a variety of reasons, including warming up the engine, maintaining comfortable cabin temperature, or while stopped in traffic. Some types of idling may be avoidable while others cannot. Most idling is done by long-haul trucks, but other types of heavy-duty vehicles, including transit buses, motor coaches, and school buses, also contribute to the idling problem. Reducing unnecessary idling can provide fuel cost savings and a decrease in maintenance costs to fleet operators while also providing clear environmental benefits.

There are several idle reduction technologies that can be installed on board vehicles to reduce the amount of idling without sacrificing vehicle energy needs or driver comfort including directfired heaters, APUs, thermal storage systems, on-board batteries, automatic engine shut-off devices, and other equipment. Additionally, parking space electrification allows the reduction of excessive stationary idling of heavy-duty vehicles by providing them with an outside power source to run vehicle accessories without running the main engine.

All of these idle reduction technologies have their advantages and limitations. APUs and battery-powered systems provide all the needs of the vehicle with little or no emissions, but they are bulky, heavy, and expensive. Direct-fired and coolant heaters are small and inexpensive but can provide only heat. Automatic engine shut-off devices are inexpensive and low-weight but have low driver acceptance. The cost of idle reduction devices can range from $\$ 1,400$ for automatic shut-off system to More than $\$ 8,000$ for an APU. Different idle reduction technologies have different payback periods, depending on the idling profile of the fleet, but with the price of diesel of $\$ 3$ per gallon, all technologies are expected to pay for themselves in $2-3$ years.

Idling can be reduced not only by means of equipment installed on board a vehicle, but also through policies. Idle reduction policies typically provide for various types of restrictions limiting the amount of idling. Such policies may include limiting engine warm-up, shutting down the engine after a certain time of idling, improving vehicle scheduling and dispatching, minimizing vehicle queuing, and other procedures. Unlike technological solutions, idle reduction policies can be implemented with little or no up-front investment. However, the success of such policies depends heavily on employee compliance.

Due to the low cost of implementation, many heavy-duty fleets have taken advantage of idle reduction policies to reduce idling. Data from the U.S. DOE Clean Cities Program show that idle reduction policies displace practically the same amount of petroleum as idle reduction equipment.

The survey of the 48 U.S. transit agencies showed that environmental concerns and saving fuel costs were the two most important reasons for reducing idling by transit fleets, followed by reduction in engine wear and other factors. The survey also revealed that transit agencies 
view the nature of fleet operations as the most important obstacle for implementing idle reduction, followed by the lack of understanding of the impact of idling and other challenges. Cost of idle reduction devices and lack of cooperation from employees are the two factors identified by the largest number of survey respondents as the second most important challenge for implementing idle reduction programs.

Federal, state, and local incentive programs can help with covering some of the incremental costs of idle reduction equipment acquisition and installation. There are 106 laws, regulations programs, and incentives dealing with idle reduction at the federal, state, and local levels in the U.S. and 55 incentives, 43 laws, and regulations and 1 fleet assistance program at the state level. A total of 41 states and the District of Columbia have some kind of incentive or law addressing idle reduction.

State incentives are represented by a combination of regulatory and financial incentives. Explicit restrictions on the amount of idling of heavy-duty vehicles account for $33.7 \%$ of all state idle reduction incentives/regulations, and financial incentives, such as direct grants, rebates, loans, tax credits and exemptions, account for $27.6 \%$ of all state incentives. Although both regulatory and financial incentives can help achieve desired results, anecdotal evidence suggests that financial incentives are more likely to be successful in achieving the intended goals, especially considering that idle reduction equipment can be rather costly.

To be successful, idle reduction programs need to be focused on specific goals, the amount of the incentive needs to be large enough to cover most of the incremental cost of the idle reduction equipment, the incentive needs to be designed in the form of a direct grant or rebate, idle reduction rules need to be enforceable, and any idle reduction rule should not only prohibit/restrict the activity (idling) but should also provide an alternative. Finally, a successful idle reduction program should always engage employees to ensure their compliance and cooperation. 


\section{Appendix A: Idle Reduction Survey Questionnaire}

\section{Introduction}

The purpose of this survey is to collect information regarding bus idle reduction technologies and practices used by transit agencies across the U.S. The survey is conducted by the National Center for Transit Research (NCTR) housed at the University of South Florida in Tampa, Florida with funding provided by U.S. DOT.

Please complete the survey questions as fully as possible. Even if you currently do not employ any idle reduction technologies or policies, your input is still very valuable to us. Your responses will allow us to evaluate the level of usage of these technologies in transit fleets nationwide.

Note: The current survey only covers bus vehicles! While answering the survey, please provide data relevant only to your bus fleet.

Please e-mail the completed survey to Alexander Kolpakov, Kolpakov@cutr.usf.edu, or mail the survey to:

University of South Florida

4202 E Fowler Ave., CUT100

Tampa, FL 33620

c/o: Alexander Kolpakov

\section{Questionnaire}

1. Please provide contact information for your agency.

\begin{tabular}{|l|l|}
\hline Contact Person: & \\
\hline Company: & \\
\hline Address: & \\
\hline City: & \\
\hline State: & \\
\hline ZIP: & \\
\hline E-mail: & \\
\hline Phone: & \\
\hline
\end{tabular}

2. Please enter the total number of buses in your fleet.

3. Do you use specific technologies or policies in your fleet to reduce idling of vehicles?

$\square$ Yes $\quad \square$ No 
4. What are the two most important motivating factors for implementing idle reduction technologies?

4.1. Most important motivating factor for implementing idle reduction technologies (check one).

Environmental concerns

Reduce noise

Save fuel costs

Reduce engine wear

Other

If you chose "other," please describe:

4.2. Second most important motivating factor for implementing idle reduction technologies (check one).

Environmental concerns

Reduce noise

Save fuel costs

Reduce engine wear

Other

If you chose "other," please describe:

5. In your opinion, what are the main two obstacles for implementing idle reduction technologies and policies (regardless of whether or not you use such technologies in your organization)?

5.1. Most significant obstacle for implementing idle reduction technologies (check one)

Cost of idle reduction devices

Lack of legislative incentives

Nature of fleet operations

Lack of cooperation from employees

Lack of understanding of the impact of idling

Lack of knowledge about available technologies

Other

If you chose "other," please describe: 
5.2. Second most significant obstacle for implementing idle reduction technologies (check one).

Cost of idle reduction devices

Lack of legislative incentives

Nature of fleet operations

Lack of cooperation from employees

Lack of understanding of the impact of idling

Lack of knowledge about available technologies

Other

If you chose "other," please describe:

6. Please indicate the type of idle reduction technologies employed by your fleet and the number of vehicles on which they are installed.

\begin{tabular}{|l|c|c|c|}
\hline \multicolumn{2}{|c|}{$\begin{array}{c}\text { Idle Reduction Technologies Used } \\
\text { (check all that apply) }\end{array}$} & $\begin{array}{c}\text { Number of Vehicles } \\
\text { Where Idle Reduction } \\
\text { Technologies are Installed }\end{array}$ & $\begin{array}{c}\text { These Vehicles } \\
\text { Represent What \% } \\
\text { of the Bus Fleet }\end{array}$ \\
\hline N/A & $\square$ & & \\
\hline Auxiliary power unit (APU) & $\square$ & & \\
\hline Direct-fired heater & $\square$ & & \\
\hline $\begin{array}{l}\text { Direct heater with thermal } \\
\text { storage }\end{array}$ & $\square$ & & \\
\hline On-board batteries & $\square$ & & \\
\hline Thermal storage & $\square$ & & \\
\hline Automatic engine shut-off & $\square$ & & \\
\hline Other & $\square$ & & \\
\hline
\end{tabular}

If you chose "other," please describe:

7. Please describe policies implemented by your fleet to reduce idling of vehicles (check all that apply).

None

Shut down engine after certain time of idling (typically 3-5 minutes)

Limit engine warm-up (typically to 2-5 minutes)

Minimize vehicle queuing

Improve vehicle scheduling/dispatching

Other

If you chose "other," please describe: 
8. In your opinion, how effective are the above policies in achieving the goals of idle reduction? (check one)

Very effective

Somewhat effective

Ineffective

Very ineffective

Don't know

9. How much fuel (gallons of diesel or gasoline) does your agency save annually as a result of implementing the above idle reduction technologies or policies?

10. Describe other benefits that your agency realized as a result of implementing idle reduction technologies and policies.

11. Please describe unexpected drawbacks (if any) experienced by your agency as a result of implementing idle reduction technologies and/or policies. 12. Are there regulatory incentives in your state or local jurisdiction that encourage idle reduction practices?

$\square$ Yes

$\square$ No

$\square$ Don't know

If you answered "Yes," please describe these incentives:

13. Are there financial incentives in your state or local jurisdiction that encourage idle reduction practices?

$\square$ Yes

$\square$ No

$\square$ Don't know

If you answered "Yes," please describe these incentives:

14. In your opinion, how effective are those incentives in reducing vehicle idling in your state and/or local jurisdiction (check one)?

Very effective

Somewhat effective

Ineffective

Very ineffective

Don't know 


\section{Appendix B: List of Surveyed Agencies}

\begin{tabular}{|c|c|c|c|c|}
\hline & Agency & $\begin{array}{l}\text { NTD } \\
\text { ID }\end{array}$ & Region & City/State \\
\hline 1 & $\begin{array}{l}\text { Massachusetts Bay Transportation Authority } \\
\text { (MBTA) }\end{array}$ & 1003 & $\begin{array}{l}\text { Region } 1 \text { (CT-MA-ME- } \\
\text { NH-RI-VT) }\end{array}$ & Boston, MA \\
\hline 2 & Rhode Island Public Transit Authority (RIPTA) & 1001 & $\begin{array}{l}\text { Region } 1 \text { (CT-MA-ME- } \\
\text { NH-RI-VT) }\end{array}$ & Providence, RI \\
\hline 3 & $\begin{array}{l}\text { Connecticut Department of Transportation - } \\
\text { (CTTRANSIT) - Hartford Division }\end{array}$ & 1048 & $\begin{array}{l}\text { Region } 1 \text { (CT-MA-ME- } \\
\text { NH-RI-VT) }\end{array}$ & Hartford, CT \\
\hline 4 & Greater Bridgeport Transit Authority (GBTA) & 1050 & $\begin{array}{l}\text { Region } 1 \text { (CT-MA-ME- } \\
\text { NH-RI-VT) }\end{array}$ & Bridgeport, CT \\
\hline 5 & Chittenden County Transportation Authority (CCTA) & 1066 & $\begin{array}{l}\text { Region } 1 \text { (CT-MA-ME- } \\
\text { NH-RI-VT) }\end{array}$ & Burlington, VT \\
\hline 6 & New Jersey Transit Corporation (NJ TRANSIT) & 2080 & Region 2 (NY-NJ) & Newark, NJ \\
\hline 7 & $\begin{array}{l}\text { Central New York Regional Transportation } \\
\text { Authority (CNY Centro) }\end{array}$ & 2018 & Region 2 (NY-NJ) & Syracuse, NY \\
\hline 8 & MTA New York City Transit & 2008 & Region 2 (NY-NJ) & New York, NY \\
\hline 9 & Capital District Transportation Authority (CDTA) & 2002 & Region 2 (NY-NJ) & Albany, NY \\
\hline 10 & MTA Bus Company (MTABUS) & 2188 & Region 2 (NY-NJ) & New York, NY \\
\hline 11 & Tompkins Consolidated Area Transit (TCAT) & 2145 & Region 2 (NY-NJ) & Ithaca, NY \\
\hline 12 & $\begin{array}{l}\text { Niagara Frontier Transportation Authority } \\
\text { (NFTA Metro) }\end{array}$ & 2004 & Region 2 (NY-NJ) & Buffalo, NY \\
\hline 13 & Regional Transit Service (RTS) & 2013 & Region 2 (NY-NJ) & Rochester, NY \\
\hline 14 & $\begin{array}{l}\text { Washington Metropolitan Area Transit Authority } \\
\text { (WMATA) }\end{array}$ & 3030 & $\begin{array}{l}\text { Region } 3 \text { (DE-DC-MD- } \\
\text { PA-VA-WV) }\end{array}$ & Washington, DC \\
\hline 15 & Ride-On Montgomery County Transit (Ride On) & 3051 & $\begin{array}{l}\text { Region } 3 \text { (DE-DC- MD- } \\
\text { PA-VA-WV) }\end{array}$ & Rockville, MD \\
\hline 16 & Port Authority of Allegheny County & 3022 & $\begin{array}{l}\text { Region } 3 \text { (DE-DC-MD- } \\
\text { PA-VA-WV) }\end{array}$ & Pittsburg, PA \\
\hline 17 & Delaware Transit Corporation (DTC) & 3075 & $\begin{array}{l}\text { Region } 3 \text { (DE-DC-MD- } \\
\text { PA-VA-WV) }\end{array}$ & Wilmington, DE \\
\hline 18 & Maryland Transit Administration (MTA) & 3034 & $\begin{array}{l}\text { Region } 3 \text { (DE-DC-MD- } \\
\text { PA-VA-WV) }\end{array}$ & Baltimore, MD \\
\hline 19 & Beaver County Transit Authority (BCTA) & 3023 & $\begin{array}{l}\text { Region } 3 \text { (DE-DC-MD- } \\
\text { PA-VA-WV) }\end{array}$ & Rochester, PA \\
\hline 20 & Centre Area Transportation Authority (CATA) & 3054 & $\begin{array}{l}\text { Region } 3 \text { (DE-DC-MD- } \\
\text { PA-VA-WV) }\end{array}$ & $\begin{array}{l}\text { State College, } \\
\text { PA }\end{array}$ \\
\hline 21 & County of Lachawanna Transit System (COLTS) & 3025 & $\begin{array}{l}\text { Region } 3 \text { (DE-DC-MD- } \\
\text { PA-VA-WV) }\end{array}$ & Scranton, PA \\
\hline 22 & County of Lebanon Transit Authority (LT) & 3095 & $\begin{array}{l}\text { Region } 3 \text { (DE-DC-MD- } \\
\text { PA-VA-WV) }\end{array}$ & Lebanon, PA \\
\hline 23 & $\begin{array}{l}\text { Southeastern Pennsylvania Transportation } \\
\text { Authority (SEPTA) }\end{array}$ & 3019 & $\begin{array}{l}\text { Region } 3 \text { (DE-DC-MD- } \\
\text { PA-VA-WV) }\end{array}$ & Philadelphia, PA \\
\hline 24 & Erie Metropolitan Transit Authority (The E) & 3013 & $\begin{array}{l}\text { Region } 3 \text { (DE-DC-MD- } \\
\text { PA-VA-WV) }\end{array}$ & Erie, PA \\
\hline 25 & $\begin{array}{l}\text { Lehigh and Northampton Transportation } \\
\text { Authority (LANTA) }\end{array}$ & 3010 & $\begin{array}{l}\text { Region } 3 \text { (DE-DC-MD- } \\
\text { PA-VA-WV) }\end{array}$ & Allentown, PA \\
\hline 26 & $\begin{array}{l}\text { Cumberland Dauphin-Harrisburg Transit } \\
\text { Authority (Capital Area Transit) }\end{array}$ & 3014 & $\begin{array}{l}\text { Region } 3 \text { (DE-DC-MD- } \\
\text { PA-VA-WV) }\end{array}$ & Harrisburg, PA \\
\hline 27 & $\begin{array}{l}\text { York County Transportation Authority } \\
\text { (Rabbittransit) }\end{array}$ & 3027 & $\begin{array}{l}\text { Region } 3 \text { (DE-DC-MD- } \\
\text { PA-VA-WV) }\end{array}$ & York, PA \\
\hline 28 & Alexandria Transit Company & 3071 & $\begin{array}{l}\text { Region } 3 \text { (DE-DC-MD- } \\
\text { PA-VA-WV) }\end{array}$ & Alexandria, VA \\
\hline 29 & Arlington Transit (ART) & 3080 & $\begin{array}{l}\text { Region } 3 \text { (DE-DC-MD- } \\
\text { PA-VA-WV) }\end{array}$ & Arlington, VA \\
\hline
\end{tabular}




\begin{tabular}{|c|c|c|c|c|}
\hline 30 & Hampton Roads Transit (HRT) & 3083 & $\begin{array}{l}\text { Region } 3 \text { (DE-DC-MD- } \\
\text { PA-VA-WV) }\end{array}$ & Hampton, VA \\
\hline 31 & $\begin{array}{l}\text { Potomac and Rappahannock Transportation } \\
\text { Commission (PRTC) }\end{array}$ & 3070 & $\begin{array}{l}\text { Region } 3 \text { (DE-DC-MD- } \\
\text { PA-VA-WV) }\end{array}$ & Woodbridge, VA \\
\hline 32 & Greater Lynchburg Transit Company (GLTC) & 3008 & $\begin{array}{l}\text { Region } 3 \text { (DE-DC-MD- } \\
\text { PA-VA-WV) }\end{array}$ & Lynchburg, VA \\
\hline 33 & The Tri-State Transit Authority (TTA) & 3002 & $\begin{array}{l}\text { Region } 3 \text { (DE-DC-MD- } \\
\text { PA-VA-WV) }\end{array}$ & Huntington, WV \\
\hline 34 & Mid-Ohio Valley Transit Authority (Easy Rider) & 3003 & $\begin{array}{l}\text { Region } 3 \text { (DE-DC-MD- } \\
\text { PA-VA-WV) }\end{array}$ & $\begin{array}{l}\text { Parkersburg, } \\
\text { WV }\end{array}$ \\
\hline 35 & $\begin{array}{l}\text { Birmingham-Jefferson County Transit Authority } \\
\text { (BJCTA) }\end{array}$ & 4042 & $\begin{array}{l}\text { Region } 4 \text { (AL-FL-GA-KY- } \\
\text { MS-NC-SC-TN) }\end{array}$ & Birmingham, AL \\
\hline 36 & The Wave Transit System (WTS) & 4043 & $\begin{array}{l}\text { Region } 4 \text { (AL-FL-GA-KY- } \\
\text { MS-NC-SC-TN) }\end{array}$ & Mobile, AL \\
\hline 37 & $\begin{array}{l}\text { Central Florida Regional Transportation } \\
\text { Authority (LYNX) }\end{array}$ & 4035 & $\begin{array}{l}\text { Region } 4 \text { (AL-FL-GA-KY- } \\
\text { MS-NC-SC-TN) }\end{array}$ & Orlando, FL \\
\hline 38 & StarMetro & 4036 & $\begin{array}{l}\text { Region } 4 \text { (AL-FL-GA-KY- } \\
\text { MS-NC-SC-TN) }\end{array}$ & Tallahassee, FL \\
\hline 39 & Broward County Transit (BCT) & 4029 & $\begin{array}{l}\text { Region } 4 \text { (AL-FL-GA-KY- } \\
\text { MS-NC-SC-TN) }\end{array}$ & Plantation, FL \\
\hline 40 & $\begin{array}{l}\text { Hillsborough Area Regional Transit Authority } \\
\text { (HART) }\end{array}$ & 4041 & $\begin{array}{l}\text { Region } 4 \text { (AL-FL-GA- } \\
\text { KY-MS-NC-SC-TN) }\end{array}$ & Tampa, FL \\
\hline 41 & Miami Dade Transit (MDT) & 4034 & $\begin{array}{l}\text { Region } 4 \text { (AL-FL-GA- } \\
\text { KY-MS-NC-SC-TN) }\end{array}$ & Miami, FL \\
\hline 42 & PalmTran & 4037 & $\begin{array}{l}\text { Region } 4 \text { (AL-FL-GA-KY- } \\
\text { MS-NC-SC-TN) }\end{array}$ & $\begin{array}{l}\text { West Palm } \\
\text { Beach, FL }\end{array}$ \\
\hline 43 & Chatham Area Transit Authority (CAT) & 4025 & $\begin{array}{l}\text { Region } 4 \text { (AL-FL-GA-KY- } \\
\text { MS-NC-SC-TN) }\end{array}$ & Savannah, GA \\
\hline 44 & Macon-Bibb County Transit Authority (MTA) & 4130 & $\begin{array}{l}\text { Region } 4 \text { (AL-FL-GA- } \\
\text { KY-MS-NC-SC-TN) }\end{array}$ & Macon, GA \\
\hline 45 & $\begin{array}{l}\text { Metropolitan Atlanta Rapid Transit Authority } \\
\text { (MARTA) }\end{array}$ & 4022 & $\begin{array}{l}\text { Region } 4 \text { (AL-FL-GA-KY- } \\
\text { MS-NC-SC-TN) }\end{array}$ & Atlanta, GA \\
\hline 46 & Transit Authority of Northern Kentucky (TANK) & 4019 & $\begin{array}{l}\text { Region } 4 \text { (AL-FL-GA-KY- } \\
\text { MS-NC-SC-TN) }\end{array}$ & Fort Wright, $\mathrm{KY}$ \\
\hline 47 & Transit Authority of River City (TARC) & 4018 & $\begin{array}{l}\text { Region } 4 \text { (AL-FL-GA-KY- } \\
\text { MS-NC-SC-TN) }\end{array}$ & Louisville, KY \\
\hline 48 & Chapel Hill Transit (CHT) & 4051 & $\begin{array}{l}\text { Region } 4 \text { (AL-FL-GA-KY- } \\
\text { MS-NC-SC-TN) }\end{array}$ & Chapel Hill, NC \\
\hline 49 & Charlotte Area Transit System (CATS) & 4008 & $\begin{array}{l}\text { Region } 4 \text { (AL-FL-GA-KY- } \\
\text { MS-NC-SC-TN) }\end{array}$ & Charlotte, NC \\
\hline 50 & Durham Area Transit Authority (DATA) & 4087 & $\begin{array}{l}\text { Region } 4 \text { (AL-FL-GA-KY- } \\
\text { MS-NC-SC-TN) }\end{array}$ & Durham, NC \\
\hline 51 & Greensboro Transit Authority (GTA) & 4093 & $\begin{array}{l}\text { Region } 4 \text { (AL-FL-GA-KY- } \\
\text { MS-NC-SC-TN) }\end{array}$ & $\begin{array}{l}\text { Greensborough, } \\
\text { NC }\end{array}$ \\
\hline 52 & $\begin{array}{l}\text { Research Triangle Regional Public } \\
\text { Transportation Authority (Triangle Transit) }\end{array}$ & 4108 & $\begin{array}{l}\text { Region } 4 \text { (AL-FL-GA-KY- } \\
\text { MS-NC-SC-TN) }\end{array}$ & $\begin{array}{l}\text { Research } \\
\text { Triangle Park, } \\
\text { NC }\end{array}$ \\
\hline 53 & Winston-Salem Transit Authority (WSTA) & 4012 & $\begin{array}{l}\text { Region } 4 \text { (AL-FL-GA-KY- } \\
\text { MS-NC-SC-TN) }\end{array}$ & $\begin{array}{l}\text { Winston-Salem, } \\
\text { NC }\end{array}$ \\
\hline 54 & $\begin{array}{l}\text { Charleston Area Regional Transportation } \\
\text { Authority (CARTA) }\end{array}$ & 4110 & $\begin{array}{l}\text { Region } 4 \text { (AL-FL-GA-KY- } \\
\text { MS-NC-SC-TN) }\end{array}$ & Charleston, SC \\
\hline 55 & Memphis Area Transit Authority (MATA) & 4003 & $\begin{array}{l}\text { Region } 4 \text { (AL-FL-GA-KY- } \\
\text { MS-NC-SC-TN) }\end{array}$ & Memphis, TN \\
\hline 56 & Nashville Metropolitan Transit Authority (MTA) & 4004 & $\begin{array}{l}\text { Region } 4 \text { (AL-FL-GA-KY- } \\
\text { MS-NC-SC-TN) }\end{array}$ & Nashville, TN \\
\hline 57 & Knoxville Area Transit (KAT) & 4002 & $\begin{array}{l}\text { Region } 4 \text { (AL-FL-GA-KY- } \\
\text { MS-NC-SC-TN) }\end{array}$ & Knoxville, TN \\
\hline
\end{tabular}




\begin{tabular}{|c|c|c|c|c|}
\hline 58 & Springfield Mass Transit District (SMTD) & 5059 & $\begin{array}{l}\text { Region } 5 \text { (IL-IN-MI- } \\
\text { MN-OH-WI) }\end{array}$ & Springfield, IL \\
\hline 59 & Champaign-Urbana Mass Transit District (CUMTD) & 5060 & $\begin{array}{l}\text { Region } 5 \text { (IL-IN-MI- } \\
\text { MN-OH-WI) }\end{array}$ & Urbana, IL \\
\hline 60 & Chicago Transit Authority (CTA) & 5066 & $\begin{array}{l}\text { Region } 5 \text { (IL-IN-MI- } \\
\text { MN-OH-WI) }\end{array}$ & Chicago, IL \\
\hline 61 & Pace - Suburban Bus Division & 5113 & $\begin{array}{l}\text { Region } 5 \text { (IL-IN-MI- } \\
\text { MN-OH-WI) }\end{array}$ & $\begin{array}{l}\text { Arlington } \\
\text { Heights, IL }\end{array}$ \\
\hline 62 & Madison County Transit District (MCT) & 5146 & $\begin{array}{l}\text { Region } 5 \text { (IL-IN-MI- } \\
\text { MN-OH-WI) }\end{array}$ & $\begin{array}{l}\text { Granite City, } \\
\text { IL }\end{array}$ \\
\hline 63 & $\begin{array}{l}\text { Rock Island County Metropolitan Mass Transit } \\
\text { District (MetroLink) }\end{array}$ & 5057 & $\begin{array}{l}\text { Region } 5 \text { (IL-IN-MI- } \\
\text { MN-OH-WI) }\end{array}$ & Moline, IL \\
\hline 64 & Bloomington Public Transportation Corporation (BT) & 5110 & $\begin{array}{l}\text { Region } 5 \text { (IL-IN-MI- } \\
\text { MN-OH-WI) }\end{array}$ & $\begin{array}{l}\text { Bloomington, } \\
\text { IN }\end{array}$ \\
\hline 65 & $\begin{array}{l}\text { Indianapolis Public Transportation Corporation } \\
\text { (IndyGo) }\end{array}$ & 5050 & $\begin{array}{l}\text { Region } 5 \text { (IL-IN-MI- } \\
\text { MN-OH-WI) }\end{array}$ & $\begin{array}{l}\text { Indianapolis, } \\
\text { IN }\end{array}$ \\
\hline 66 & $\begin{array}{l}\text { Greater Lafayette Public Transportation } \\
\text { Corporation (CityBus) }\end{array}$ & 5051 & $\begin{array}{l}\text { Region } 5 \text { (IL-IN-MI- } \\
\text { MN-OH-WI) }\end{array}$ & yette, IN \\
\hline 67 & $\begin{array}{l}\text { Northern Indiana Commuter Transportation } \\
\text { District (NICTD) }\end{array}$ & 5104 & $\begin{array}{l}\text { Region } 5 \text { (IL-IN-MI- } \\
\text { MN-OH-WI) }\end{array}$ & $\begin{array}{l}\text { Chesterton, } \\
\text { IN }\end{array}$ \\
\hline 68 & $\begin{array}{l}\text { South Bend Public Transportation Corporation } \\
\text { (Transpo) }\end{array}$ & 5052 & $\begin{array}{l}\text { Region } 5 \text { (IL-IN-MI- } \\
\text { MN-OH-WI) }\end{array}$ & $\begin{array}{l}\text { South Bend, } \\
\text { IN }\end{array}$ \\
\hline 69 & Ann Arbor Transportation Authority (TheRide) & 5040 & $\begin{array}{l}\text { Region } 5 \text { (IL-IN-MI- } \\
\text { MN-OH-WI) }\end{array}$ & Ann Arbor, MI \\
\hline 70 & Capital Area Transportation Authority (CATA) & 5036 & $\begin{array}{l}\text { Region } 5 \text { (IL-IN-MI- } \\
\text { MN-OH-WI) }\end{array}$ & Lansing, MI \\
\hline 71 & City of Detroit Department of Transportation & 5119 & $\begin{array}{l}\text { Region } 5 \text { (IL-IN-MI- } \\
\text { MN-OH-WI) }\end{array}$ & Detroit, MI \\
\hline 72 & Interurban Transit Partnership (The Rapid) & 5033 & $\begin{array}{l}\text { Region } 5 \text { (IL-IN-MI- } \\
\text { MN-OH-WI) }\end{array}$ & $\begin{array}{l}\text { Grand Rapids, } \\
\text { MI }\end{array}$ \\
\hline 73 & Mass Transportation Authority (MTA) & 5032 & $\begin{array}{l}\text { Region } 5 \text { (IL-IN-MI- } \\
\text { MN-OH-WI) }\end{array}$ & Flint, MI \\
\hline 74 & Bay Metropolitan Transit Authority (Bay Metro) & 5029 & $\begin{array}{l}\text { Region } 5 \text { (IL-IN-MI- } \\
\text { MN-OH-WI) }\end{array}$ & Bay City, MI \\
\hline 75 & St. Cloud Metropolitan Transit Commission (MTC) & 5028 & $\begin{array}{l}\text { Region } 5 \text { (IL-IN-MI- } \\
\text { MN-OH-WI) }\end{array}$ & St. Cloud, MN \\
\hline 76 & Metro Transit & 5027 & $\begin{array}{l}\text { Region } 5 \text { (IL-IN-MI- } \\
\text { MN-OH-WI) }\end{array}$ & $\begin{array}{l}\text { Minneapolis, } \\
\text { MN }\end{array}$ \\
\hline 77 & METRO Regional Transit Authority (METRO RTA) & 5010 & $\begin{array}{l}\text { Region } 5 \text { (IL-IN-MI- } \\
\text { MN-OH-WI) }\end{array}$ & Akron, $\mathrm{OH}$ \\
\hline 78 & Central Ohio Transit Authority (COTA) & 5016 & $\begin{array}{l}\text { Region } 5 \text { (IL-IN-MI- } \\
\text { MN-OH-WI) }\end{array}$ & $\begin{array}{l}\text { Columbus, } \\
\mathrm{OH}\end{array}$ \\
\hline 79 & $\begin{array}{l}\text { Greater Cleveland Regional Transit Authority } \\
\text { (GCRTA) }\end{array}$ & 5015 & $\begin{array}{l}\text { Region } 5 \text { (IL-IN-MI- } \\
\text { MN-OH-WI) }\end{array}$ & Cleveland, $\mathrm{OH}$ \\
\hline 80 & Greater Dayton Regional Transit Authority (GDRTA) & 5017 & $\begin{array}{l}\text { Region } 5 \text { (IL-IN-MI- } \\
\text { MN-OH-WI) }\end{array}$ & Dayton, OH \\
\hline 81 & Southwest Ohio Regional Transit Authority (SORTA) & 5012 & $\begin{array}{l}\text { Region } 5 \text { (IL-IN-MI- } \\
\text { MN-OH-WI) }\end{array}$ & Cincinnati, $\mathrm{OH}$ \\
\hline 82 & Toledo Area Regional Transit Authority (TARTA) & 5022 & $\begin{array}{l}\text { Region } 5 \text { (IL-IN-MI- } \\
\text { MN-OH-WI) }\end{array}$ & Toledo, $\mathrm{OH}$ \\
\hline 83 & Madison Metro Transit System (Metro) & 5005 & $\begin{array}{l}\text { Region } 5 \text { (IL-IN-MI- } \\
\text { MN-OH-WI) }\end{array}$ & Madison, WI \\
\hline 84 & Milwaukee County Transit System (MCTS) & 5008 & $\begin{array}{l}\text { Region } 5 \text { (IL-IN-MI- } \\
\text { MN-OH-WI) }\end{array}$ & $\begin{array}{l}\text { Milwaukee, } \\
\text { WI }\end{array}$ \\
\hline 85 & Central Arkansas Transit Authority & 6033 & $\begin{array}{l}\text { Region } 6 \text { (AR-LA-NM- } \\
\text { OK-TX) }\end{array}$ & $\begin{array}{l}\text { North Little } \\
\text { Rock, AR }\end{array}$ \\
\hline
\end{tabular}




\begin{tabular}{|c|c|c|c|c|}
\hline 86 & New Orleans Regional Transit Authority & 6032 & $\begin{array}{l}\text { Region } 6 \text { (AR-LA-NM- } \\
\text { OK-TX) }\end{array}$ & $\begin{array}{l}\text { New Orleans, } \\
\text { LA }\end{array}$ \\
\hline 87 & City of Albuquerque Transit Department (ABQ Ride) & 6019 & $\begin{array}{l}\text { Region } 6 \text { (AR-LA-NM- } \\
\text { OK-TX) }\end{array}$ & $\begin{array}{l}\text { Albuquerque, } \\
\text { NM }\end{array}$ \\
\hline 88 & $\begin{array}{l}\text { Central Oklahoma Transportation and Parking } \\
\text { Authority (COTPA) }\end{array}$ & 6017 & $\begin{array}{l}\text { Region } 6 \text { (AR-LA-NM- } \\
\text { OK-TX) }\end{array}$ & $\begin{array}{l}\text { Oklahoma } \\
\text { City, OK }\end{array}$ \\
\hline 89 & The Lawton Area Transit System (LATS) & 6094 & $\begin{array}{l}\text { Region } 6 \text { (AR-LA NM- } \\
\text { OK-TX) }\end{array}$ & Lawton, OK \\
\hline 90 & $\begin{array}{l}\text { Capital Metropolitan Transportation Authority } \\
\text { (CMTA) }\end{array}$ & 6048 & $\begin{array}{l}\text { Region } 6 \text { (AR-LA-NM- } \\
\text { OK-TX) }\end{array}$ & Austin, TX \\
\hline 91 & City Transit Management Company, Inc. (Citibus) & 6010 & $\begin{array}{l}\text { Region } 6 \text { (AR-LA-NM- } \\
\text { OK-TX) }\end{array}$ & Lubbock, TX \\
\hline 92 & Dallas Area Rapid Transit (DART) & 6056 & $\begin{array}{l}\text { Region } 6 \text { (AR-LA-NM- } \\
\text { OK-TX) }\end{array}$ & Dallas, TX \\
\hline 93 & Denton County Transportation Authority (DCTA) & 6101 & $\begin{array}{l}\text { Region } 6 \text { (AR-LA-NM- } \\
\text { OK-TX) }\end{array}$ & Lewisville, TX \\
\hline 94 & $\begin{array}{l}\text { Mass Transit Department - City of El Paso (Sun } \\
\text { Metro) }\end{array}$ & 6006 & $\begin{array}{l}\text { Region } 6 \text { (AR-LA- NM- } \\
\text { OK-TX) }\end{array}$ & El Paso, TX \\
\hline 95 & $\begin{array}{l}\text { Metropolitan Transit Authority of Harris County } \\
\text { (Metro) }\end{array}$ & 6008 & $\begin{array}{l}\text { Region } 6 \text { (AR-LA-NM- } \\
\text { OK-TX) }\end{array}$ & Houston, TX \\
\hline 96 & VIA Metropolitan Transit (VIA) & 6011 & $\begin{array}{l}\text { Region } 6 \text { (AR-LA-NM- } \\
\text { OK-TX) }\end{array}$ & $\begin{array}{l}\text { San Antonio, } \\
\text { TX }\end{array}$ \\
\hline 97 & Waco Transit System (WTS) & 6012 & $\begin{array}{l}\text { Region } 6 \text { (AR-LA-NM- } \\
\text { OK-TX) }\end{array}$ & Waco, TX \\
\hline 98 & Fort Worth Transportation Authority & 6007 & $\begin{array}{l}\text { Region } 6 \text { (AR-LA-NM- } \\
\text { OK-TX) }\end{array}$ & $\begin{array}{l}\text { Fort Worth, } \\
\text { TX }\end{array}$ \\
\hline 99 & Ames Transit Agency (CyRide) & 7041 & $\begin{array}{l}\text { Region } 7 \text { (IA-KS-MO- } \\
\text { NE) }\end{array}$ & Ames, IA \\
\hline \begin{tabular}{|l|l}
10 \\
0
\end{tabular} & $\begin{array}{l}\text { Des Moines Area Regional Transit Authority } \\
\text { (DART) }\end{array}$ & 7010 & $\begin{array}{l}\text { Region } 7 \text { (IA-KS-MO- } \\
\text { NE) }\end{array}$ & $\begin{array}{l}\text { Des Moines, } \\
\text { IA }\end{array}$ \\
\hline 101 & Bi-State Development Agency (DBA Metro) & 7006 & $\begin{array}{l}\text { Region } 7 \text { (IA-KS-MO- } \\
\text { NE) }\end{array}$ & St. Louis, MO \\
\hline 102 & $\begin{array}{l}\text { Kansas City Area Transportation Authority } \\
\text { (KCATA) }\end{array}$ & 7005 & $\begin{array}{l}\text { Region } 7 \text { (IA-KS-MO- } \\
\mathrm{NE} \text { ) }\end{array}$ & $\begin{array}{l}\text { Kansas City, } \\
\text { MO }\end{array}$ \\
\hline 103 & City Utilities of Springfield (The Bus) & 7003 & $\begin{array}{l}\text { Region } 7 \text { (IA-KS-MO- } \\
\text { NE) }\end{array}$ & $\begin{array}{l}\text { Springfield, } \\
\text { MO }\end{array}$ \\
\hline 104 & $\begin{array}{l}\text { Denver Regional Transportation District } \\
\text { (RTD) }\end{array}$ & 8006 & $\begin{array}{l}\text { Region } 8 \text { (CO-MT-ND- } \\
\text { SD-UT-WY) }\end{array}$ & Denver, CO \\
\hline 105 & Mountain Metropolitan Transit (MMT) & 8005 & $\begin{array}{l}\text { Region } 8 \text { (CO-MT-ND- } \\
\text { SD-UT-WY) }\end{array}$ & $\begin{array}{l}\text { Colorado } \\
\text { Springs, Co }\end{array}$ \\
\hline 106 & Transfort & 8011 & $\begin{array}{l}\text { Region } 8 \text { (CO-MT-ND- } \\
\text { SD-UT-WY) }\end{array}$ & $\begin{array}{l}\text { Fort } \\
\text { Collins, CO }\end{array}$ \\
\hline 107 & Missoula Urban Transportation District & 8009 & $\begin{array}{l}\text { Region } 8 \text { (CO-MT-ND- } \\
\text { SD-UT-WY) }\end{array}$ & $\begin{array}{l}\text { Missoula, } \\
\text { MT }\end{array}$ \\
\hline 108 & $\begin{array}{l}\text { Fargo Metropolitan Area Transit System } \\
\text { (MATBUS) }\end{array}$ & 8003 & $\begin{array}{l}\text { Region } 8 \text { (CO-MT-ND- } \\
\text { SD-UT-WY) }\end{array}$ & Fargo, ND \\
\hline 109 & Sioux Area Metro (SAM) & 8002 & $\begin{array}{l}\text { Region } 8 \text { (CO-MT-ND- } \\
\text { SD-UT-WY) }\end{array}$ & $\begin{array}{l}\text { Sioux Falls, } \\
\text { SD }\end{array}$ \\
\hline 110 & Utah Transit Authority (UTA) & 8001 & $\begin{array}{l}\text { Region } 8 \text { (CO-MT-ND- } \\
\text { SD-UT-WY) }\end{array}$ & $\begin{array}{l}\text { Salt Lake } \\
\text { City, UT }\end{array}$ \\
\hline
\end{tabular}




\begin{tabular}{|c|c|c|c|c|}
\hline 111 & $\begin{array}{l}\text { City of Phoenix Public Transit Department (Valley } \\
\text { Metro) }\end{array}$ & 9032 & $\begin{array}{l}\text { Region } 9 \text { (AZ-CA-HI- } \\
\text { NV) }\end{array}$ & Phoenix, AZ \\
\hline 112 & City of Tempe Transit Division (TIM) & 9172 & $\begin{array}{l}\text { Region } 9 \text { (AZ-CA-HI- } \\
\text { NV) }\end{array}$ & Tempe, AZ \\
\hline 113 & $\begin{array}{l}\text { Northern Arizona Intergovernmental Public } \\
\text { Transportation Authority (NAIPTA) }\end{array}$ & 9219 & $\begin{array}{l}\text { Region } 9 \text { (AZ-CA-HI- } \\
\text { NV) }\end{array}$ & Flagstaff, AZ \\
\hline 114 & Alameda-Contra Costa Transit District (AC Transit) & 9014 & $\begin{array}{l}\text { Region } 9 \text { (AZ-CA-HI- } \\
\text { NV) }\end{array}$ & Oakland, CA \\
\hline 115 & Central Contra Costa Transit Authority (CCCTA) & 9078 & $\begin{array}{l}\text { Region } 9 \text { (AZ-CA-HI- } \\
\text { NV) }\end{array}$ & Concord, CA \\
\hline 116 & $\begin{array}{l}\text { Golden Gate Bridge, Highway and Transportation } \\
\text { District (GGBHTD) }\end{array}$ & 9016 & $\begin{array}{l}\text { Region } 9 \text { (AZ-CA-HI- } \\
\text { NV) }\end{array}$ & $\begin{array}{l}\text { San Francisco, } \\
\text { CA }\end{array}$ \\
\hline 117 & Golden Empire Transit District (GET) & 9004 & $\begin{array}{l}\text { Region } 9 \text { (AZ-CA-HI- } \\
\text { NV) }\end{array}$ & Bakersfield, CA \\
\hline 118 & Foothill Transit & 9146 & $\begin{array}{l}\text { Region } 9 \text { (AZ-CA-HI- } \\
\text { NV) }\end{array}$ & $\begin{array}{l}\text { West Covina, } \\
\text { CA }\end{array}$ \\
\hline 119 & Riverside Transit Agency (RTA) & 9031 & $\begin{array}{l}\text { Region } 9 \text { (AZ-CA-HI- } \\
\text { NV) }\end{array}$ & Riverside, CA \\
\hline 120 & Long Beach Transit & 9023 & $\begin{array}{l}\text { Region } 9 \text { (AZ-CA-HI- } \\
\text { NV) }\end{array}$ & $\begin{array}{l}\text { Long Beach, } \\
\text { CA }\end{array}$ \\
\hline 121 & $\begin{array}{l}\text { Los Angeles County Metropolitan } \\
\text { Transportation Authority (LACMTA) }\end{array}$ & 9154 & $\begin{array}{l}\text { Region } 9 \text { (AZ-CA-HI- } \\
\text { NV) }\end{array}$ & $\begin{array}{l}\text { Los Angeles, } \\
\text { CA }\end{array}$ \\
\hline 122 & North County Transit District (NCTD) & 9030 & $\begin{array}{l}\text { Region } 9 \text { (AZ-CA-HI- } \\
\text { NV) }\end{array}$ & Oceanside, CA \\
\hline 123 & Omnitrans & 9029 & $\begin{array}{l}\text { Region } 9 \text { (AZ-CA-HI- } \\
\text { NV) }\end{array}$ & $\begin{array}{l}\text { San } \\
\text { Bernardino, CA }\end{array}$ \\
\hline 124 & $\begin{array}{l}\text { Orange County Transportation Authority } \\
\text { (OCTA) }\end{array}$ & 9036 & $\begin{array}{l}\text { Region } 9 \text { (AZ-CA-HI- } \\
\text { NV) }\end{array}$ & Orange, CA \\
\hline 125 & San Diego Metropolitan Transit System (MTS) & 9026 & $\begin{array}{l}\text { Region } 9 \text { (AZ-CA-HI- } \\
\text { NV) }\end{array}$ & San Diego, CA \\
\hline 126 & $\begin{array}{l}\text { San Mateo County Transit District (Sam } \\
\text { Trans) }\end{array}$ & 9009 & $\begin{array}{l}\text { Region } 9 \text { (AZ-CA-HI- } \\
\text { NV) }\end{array}$ & San Carlos, CA \\
\hline 127 & Santa Clara Valley Transportation Authority (VTA) & 9013 & $\begin{array}{l}\text { Region } 9 \text { (AZ-CA-HI- } \\
\text { NV) }\end{array}$ & San Jose, CA \\
\hline 128 & $\begin{array}{l}\text { Santa Barbara Metropolitan Transit District } \\
\text { (SBMTD) }\end{array}$ & 9020 & $\begin{array}{l}\text { Region } 9 \text { (AZ-CA-HI- } \\
\text { NV) }\end{array}$ & $\begin{array}{l}\text { Santa Barbara, } \\
\text { CA }\end{array}$ \\
\hline 129 & Santa Monica's Big Blue Bus & 9008 & Region 9 (AZ-CA-HI-V) & $\begin{array}{l}\text { Santa Monica, } \\
\text { CA }\end{array}$ \\
\hline 130 & $\begin{array}{l}\text { City and County of Honolulu Department of } \\
\text { Transportation Services (DTS) }\end{array}$ & 9002 & $\begin{array}{l}\text { Region } 9 \text { (AZ-CA-HI- } \\
\text { NV) }\end{array}$ & Honolulu, HI \\
\hline 131 & $\begin{array}{l}\text { Regional Transportation Commission of } \\
\text { Southern Nevada (RTCSN) }\end{array}$ & 9045 & $\begin{array}{l}\text { Region } 9 \text { (AZ-CA-HI- } \\
\text { NV) }\end{array}$ & Las Vegas, NV \\
\hline 132 & $\begin{array}{l}\text { Regional Transportation Commission of } \\
\text { Washoe County (RTC) }\end{array}$ & 9001 & $\begin{array}{l}\text { Region } 9 \text { (AZ-CA-HI- } \\
\text { NV) }\end{array}$ & Reno, NV \\
\hline
\end{tabular}




\begin{tabular}{|l|l|l|l|l|}
\hline 133 & Valley Regional Transit (VRT) & 0011 & $\begin{array}{l}\text { Region 10 (AK-ID-OR- } \\
\text { WA }\end{array}$ & Meridian, ID \\
\hline 134 & Lane Transit District (LTD) & 0007 & $\begin{array}{l}\text { Region 10 (AK-ID-OR- } \\
\text { WA) }\end{array}$ & Springfield, OR \\
\hline 135 & $\begin{array}{l}\text { Tri-County Metropolitan Transportation } \\
\text { District of Oregon (TriMet) }\end{array}$ & 0008 & $\begin{array}{l}\text { Region 10 (AK-ID-OR- } \\
\text { WA) }\end{array}$ & Portland, OR \\
\hline 136 & $\begin{array}{l}\text { Clark County Public Transportation Benefit } \\
\text { Area Authority (C-Tran) }\end{array}$ & 0024 & $\begin{array}{l}\text { Region 10 (AK-ID-OR- } \\
\text { WA) }\end{array}$ & Vancouver, WA \\
\hline 137 & $\begin{array}{l}\text { King County Department of Transportation - } \\
\text { Metro Transit Division }\end{array}$ & 0001 & $\begin{array}{l}\text { Region 10 (AK-ID-OR- } \\
\text { WA) }\end{array}$ & Seattle, WA \\
\hline 138 & $\begin{array}{l}\text { Pierce County Transportation Benefit Area } \\
\text { Authority (Pierce Transit) }\end{array}$ & 0003 & $\begin{array}{l}\text { Region 10 (AK-ID- OR- } \\
\text { WA) }\end{array}$ & Tacoma, WA \\
\hline 139 & $\begin{array}{l}\text { Snohomish County Public Transportation } \\
\text { Benefit Area Corporation (Community Transit) }\end{array}$ & 0029 & $\begin{array}{l}\text { Region 10 (AK-ID-OR- } \\
\text { WA) }\end{array}$ & Everett, WA \\
\hline 140 & Intercity Transit & 0019 & $\begin{array}{l}\text { Region 10 (AK-ID-OR- } \\
\text { WA) }\end{array}$ & Olympia, WA \\
\hline 141 & Spokane Transit Authority (STA) & 0002 & $\begin{array}{l}\text { Region 10 (AK-ID- OR- } \\
\text { WA) }\end{array}$ & Spokane, WA \\
\hline
\end{tabular}




\section{Appendix C: Idle Reduction Regulations \& Incentives}

\begin{tabular}{|c|c|c|}
\hline Jurisdiction & Type & Title/Description \\
\hline Federal & Program & $\begin{array}{l}\text { SmartWay Transport Partnership is a market-based public-private } \\
\text { collaboration between the U.S. Environmental Protection Agency (EPA) and } \\
\text { the domestic freight industry. This partnership is designed to reduce } \\
\text { greenhouse gases and air pollution by accelerating the adoption of } \\
\text { advanced technologies and operational practices which increase fuel } \\
\text { efficiency and reduce emissions from goods movement. EPA provides } \\
\text { partners with performance benchmarking tools, fleet management best } \\
\text { practices, technology verification, public recognition and awards, and use of } \\
\text { the SmartWay Transport Partner logo to demonstrate their leadership to } \\
\text { customers, shareholders and other stakeholders. The SmartWay Transport } \\
\text { Partnership is working with partners to test and verify advanced } \\
\text { technologies ( http://epa.gov/ smartway/forpartners/technology.htm) and } \\
\text { operational practices that save fuel and reduce emissions. Grants are } \\
\text { available to states, nonprofits, and academic institutions to demonstrate } \\
\text { innovative idle reduction technologies for the trucking industry. For more } \\
\text { information, see http://www.epa.gov/smartway/. }\end{array}$ \\
\hline Federal & Program & $\begin{array}{l}\text { Clean School Bus USA is a public-private partnership that focuses on } \\
\text { reducing children's exposure to harmful diesel exhaust by limiting school } \\
\text { bus idling, implementing pollution reduction technologies, improving route } \\
\text { logistics, and switching to clean fuels. Clean School Bus USA is part of the } \\
\text { U.S. Environmental Protection Agency's National Clean Diesel Campaign } \\
\text { (http://www.epa.gov/ cleandiesel/) and provides funding for projects } \\
\text { designed to retrofit and/or replace older diesel school buses. Eligible } \\
\text { applicants are school districts, state and local government programs, } \\
\text { federally recognized Indian tribes, and non-profit organizations. For more } \\
\text { information, see http://www.epa.gov/ cleanschoolbus/. }\end{array}$ \\
\hline Federal & Program & $\begin{array}{l}\text { Clean Cities The mission of Clean Cities is to advance the energy, } \\
\text { economic, and environmental security of the United States by supporting } \\
\text { local initiatives to adopt practices that reduce the use of petroleum in the } \\
\text { transportation sector. Clean Cities carries out this mission through a } \\
\text { network of nearly } 100 \text { volunteer coalitions, which develop public/private } \\
\text { partnerships to promote alternative fuels and advanced vehicles, fuel } \\
\text { blends, fuel economy, hybrid vehicles, and idle reduction. Clean Cities } \\
\text { provides information about financial opportunities, coordinates technical } \\
\text { assistance projects, updates and maintains databases and websites, and } \\
\text { publishes fact sheets, newsletters, and related technical and informational } \\
\text { materials. For more information, see } \\
\text { http://www1.eere.energy.gov/cleancities/. }\end{array}$ \\
\hline Federal & Program & $\begin{array}{l}\text { National Clean Diesel Campaign (NCDC) (http://www.epa.gov/ } \\
\text { cleandiesel/) was established by the U.S. Environmental Protection Agency } \\
\text { to reduce pollution emitted from diesel engines through the implementation } \\
\text { of varied control strategies and the involvement of national, state, and } \\
\text { local partners. The NCDC includes programs for existing diesel fleets, } \\
\text { regulations for clean diesel engines and fuels, and regional collaborations } \\
\text { and partnerships. For information on available grants and funding } \\
\text { opportunities, see http://www.epa.gov/cleandiesel/grantfund.htm. }\end{array}$ \\
\hline Federal & Incentive & $\begin{array}{l}\text { Idle Reduction Equipment Excise Tax Exemption Qualified on-board } \\
\text { idle reduction devices and advanced insulation are exempt from the federal } \\
\text { excise tax imposed on the retail sale of heavy-duty highway trucks and } \\
\text { trailers. The exemption also applies to the installation of qualified } \\
\text { equipment on vehicles after the vehicles have been placed into service. For } \\
\text { a list of eligible products and additional information about product } \\
\text { exemption eligibility criteria, see http://www.epa.gov/smartway/ } \\
\text { forpartners/ technology.htm. The exemption applies to equipment that was }\end{array}$ \\
\hline
\end{tabular}




\begin{tabular}{|c|c|c|}
\hline & & $\begin{array}{l}\text { determined by the Administrator of the EPA, in consultation with the } \\
\text { Secretary of Energy and the Secretary of Transportation, to reduce the } \\
\text { idling of the tractor at a motor vehicle rest stop or other location where } \\
\text { such vehicles are temporarily parked or remain stationary. Only equipment } \\
\text { sold on or after October } 4,2008 \text {, is eligible. For more information, see } \\
\text { http://www.irs.gov/pub/irs-pdf/p510.pdf and the instructions for IRS Form } \\
720 \text { at http://apps.irs.gov/app/picklist/list/ formsPublications.html. }\end{array}$ \\
\hline Federal & Program & $\begin{array}{l}\text { Congestion Mitigation and Air Quality (CMAQ) Improvement } \\
\text { Program provides funding to state departments of transportation (DOTs), } \\
\text { municipal planning organizations (MPOs), and transit agencies for projects } \\
\text { and programs in air quality nonattainment and maintenance areas that } \\
\text { reduce transportation-related emissions. Eligible activities include transit } \\
\text { improvements, travel demand management strategies, traffic flow } \\
\text { improvements, purchasing idle reduction equipment, development of } \\
\text { alternative fueling infrastructure, conversion of public fleet vehicles to } \\
\text { operate on cleaner fuels, and outreach activities that provide assistance to } \\
\text { diesel equipment and vehicle owners and operators regarding the purchase } \\
\text { and installation of diesel retrofits. State DOTs and MPOs must give priority } \\
\text { to projects and programs to include diesel retrofits and other cost-effective } \\
\text { emissions reduction activities, and cost-effective congestion mitigation } \\
\text { activities that provide air quality benefits. For more information, see } \\
\text { http://www.fhwa.dot.gov/environment/air_quality/ cmaq/. (Reference } \\
\text { Public Law 112-141, and } 23 \text { U.S. Code 149) }\end{array}$ \\
\hline Federal & $\begin{array}{l}\text { Laws \& } \\
\text { Regulations }\end{array}$ & $\begin{array}{l}\text { Idle Reduction Technology Weight Exemption States may allow } \\
\text { heavy-duty vehicles equipped with idle reduction technology to exceed } \\
\text { the maximum gross vehicle weight limit and the axle weight limit by up } \\
\text { to } 550 \text { pounds (Ibs) to compensate for the additional weight of the idle } \\
\text { reduction technology. This allowance does not impact state highway } \\
\text { funding eligibility. (Reference Public Law } 112-141 \text { and } 23 \text { U.S. Code } \\
127(a)(12) \text { ) }\end{array}$ \\
\hline Alabama & $\begin{array}{l}\text { Laws \& } \\
\text { Regulations }\end{array}$ & $\begin{array}{l}\text { Fuel-Efficient Green Fleets Policy and Fleet Management Program } \\
\text { Development The Alabama Green Fleets Review Committee } \\
\text { (Committee) is establishing a Green Fleets Policy (Policy) outlining a } \\
\text { procedure for procuring state vehicles based on criteria that includes fuel } \\
\text { economy and lifecycle costing. State fleet managers must classify their } \\
\text { vehicle inventory for compliance with the Policy and submit annual plans } \\
\text { for procuring fuel-efficient vehicles. These plans must reflect a } 4 \% \text { annual } \\
\text { increase in average fleet fuel economy for light-duty vehicles, a } 3 \% \\
\text { annual increase in average fleet fuel economy for medium-duty vehicles, } \\
\text { and a } 2 \% \text { annual increase in average fleet fuel economy for heavy-duty } \\
\text { vehicles per fiscal year. The Policy will also require that government } \\
\text { entities manage and operate their fleets in a manner that is energy } \\
\text { efficient, minimizes emissions, and reduces petroleum dependency by } \\
\text { using specified proven technology the Committee identifies. In addition, } \\
\text { the Alabama Department of Transportation appointed and employed a } \\
\text { fleet manager to develop a statewide fleet management program } \\
\text { (Program). The Office of Fleet Management will propose fleet } \\
\text { management policies, procedures, and guidelines for all state agency, } \\
\text { board, commission, and department fleets and will address future } \\
\text { cooperation between the Department of Finance and the Committee to } \\
\text { ensure compliance with the Green Fleets Policy. (Reference Code of } \\
\text { Alabama } 41-17 \text { A-1 through } 41-17 A-6, \text { and Executive Order } 38,2013 \text { ) }\end{array}$ \\
\hline
\end{tabular}




\begin{tabular}{|c|c|c|}
\hline Jurisdiction & Type & Title/Description \\
\hline Alabama & $\begin{array}{l}\text { State } \\
\text { Incentive }\end{array}$ & $\begin{array}{l}\text { Alternative Fuel Vehicle (AFV) Revolving Loan Program for Public } \\
\text { Entities The Alabama Department of Economic and Community Affairs } \\
\text { (ADECA) provides low-interest loans for a variety of energy efficiency } \\
\text { improvement projects, including those involving idle reduction equipment } \\
\text { and natural gas and propane vehicle conversion or purchases. Dedicated } \\
\text { and bi-fuel vehicles are eligible, and the loan may cover incremental and } \\
\text { conversion costs. Local governments and public colleges and universities } \\
\text { can borrow up to } \$ 350,000 ; \mathrm{K}-12 \text { public schools can borrow up to } \$ 350,000 \\
\text { per campus or } \$ 500,000 \text { per school system. The minimum loan amount is } \\
\$ 50,000 \text { and the maximum loan term is five years. For more information, } \\
\text { see the Local Government Energy Loan Program website } \\
\text { (http://adeca.alabama.gov/Divisions/energy/Pages/EnergyFinancing.aspx). }\end{array}$ \\
\hline Alabama & $\begin{array}{l}\text { State } \\
\text { Incentive }\end{array}$ & $\begin{array}{l}\text { Idle Reduction Weight Exemption Any motor vehicle equipped with an } \\
\text { auxiliary power unit (APU) or other idle reduction technology may exceed } \\
\text { the gross, axle, tandem, or bridge formula weight limits by up to } 400 \\
\text { pounds. To be eligible for the weight exemption, the vehicle operator must } \\
\text { be able to provide written proof or certification of the weight of the APU and } \\
\text { demonstrate or certify that the idle reduction technology is fully functional } \\
\text { at all times. (Reference Code of Alabama } 32-9-20 \text { ) }\end{array}$ \\
\hline Alaska & $\begin{array}{l}\text { State } \\
\text { Incentive }\end{array}$ & $\begin{array}{l}\text { Idle Reduction Weight Exemption A commercial vehicle equipped with } \\
\text { qualified idle reduction technology may exceed the state's gross, total axle, } \\
\text { or bridge formula vehicle weight limits by up to } 400 \text { pounds to compensate } \\
\text { for the additional weight of the idle reduction technology. Upon request, } \\
\text { vehicle operators must provide proof that the idle reduction technology is } \\
\text { fully functional. (Reference Alaska Administrative Code } 17.25 .013 \text { ) }\end{array}$ \\
\hline Arizona & \begin{tabular}{|l} 
Laws \& \\
Regulations
\end{tabular} & $\begin{array}{l}\text { School Bus Idle Reduction Pilot Program As part of the Children's } \\
\text { Environmental Health Project, the Arizona Department of Environmental } \\
\text { Quality (ADEQ) administers the School Bus Idling Pilot Program to reduce } \\
\text { bus idling near schools. ADEQ has worked with school districts to develop a } \\
\text { draft bus idling policy, which many of the school districts involved in the } \\
\text { pilot program have implemented. Key elements in the draft policy include: } \\
\text { having drivers turn off buses upon reaching a school or other location and } \\
\text { not turn on the engine until the vehicle is ready to depart; parking buses at } \\
\text { least } 100 \text { feet from a school air intake system; and posting appropriate } \\
\text { signage advising drivers to limit idling near the school. For more } \\
\text { information, refer to http://www.azdeq.gov/ceh/ bus.html. }\end{array}$ \\
\hline Arizona & \begin{tabular}{|l} 
State \\
Incentive
\end{tabular} & $\begin{array}{l}\text { Idle Reduction Weight Exemption A heavy-duty vehicle that is equipped } \\
\text { with qualified idle reduction technology may exceed the state's gross, total } \\
\text { axle, or bridge formula vehicle weight limits by up to } 400 \text { pounds to } \\
\text { accommodate the weight of the idle reduction technology. (Reference } \\
\text { Arizona Revised Statutes } 28-1100 \text { ) }\end{array}$ \\
\hline Arkansas & $\begin{array}{l}\text { State } \\
\text { Incentive }\end{array}$ & $\begin{array}{l}\text { Idle Reduction Technology Loans The Arkansas Department of } \\
\text { Environmental Quality (ADEQ) provides small business loans at } 80 \% \text { of the } \\
\text { current prime interest rate to institute pollution control and prevention } \\
\text { measures. Idle reduction technologies for heavy-duty trucking applications } \\
\text { are eligible. The maximum loan amount is } \$ 45,000, \text { with a } \$ 65,000 \text { lifetime } \\
\text { maximum for one business. An eligible business must employ } 100 \\
\text { individuals or less and demonstrate proof of profitability and the ability to } \\
\text { repay the loan. For more information, including a loan application, see } \\
\text { http://www.adeq. state.ar.us/poa/sba/envloans.htm. }\end{array}$ \\
\hline California & $\begin{array}{l}\text { Laws \& } \\
\text { Regulations }\end{array}$ & $\begin{array}{l}\text { Heavy-Duty Truck Idle Reduction Requirements A driver of a diesel- } \\
\text { fueled vehicle with a gross vehicle weight rating of more than } 10,000 \\
\text { pounds may not idle the vehicle's primary engine for more than five minutes } \\
\text { at any location, and is not allowed to operate a diesel-fueled auxiliary power } \\
\text { system (APS) on the vehicle for more than five minutes when located within } \\
100 \text { feet of a restricted area. Exceptions apply in certain situations and for } \\
\text { certain vehicles. Any internal combustion APS used in California must }\end{array}$ \\
\hline
\end{tabular}




\begin{tabular}{|c|c|c|}
\hline & & $\begin{array}{l}\text { comply with applicable state off-road and/or federal non-road emissions } \\
\text { standards and test procedures for its fuel type and power category to ensure } \\
\text { that emissions do not exceed the emissions of a truck engine operating at } \\
\text { idle. Model Year } 2008 \text { and newer heavy-duty diesel engines must be } \\
\text { equipped with non-programmable engine shutdown systems that } \\
\text { automatically shut down the engine after five minutes of idling or optionally } \\
\text { meet a stringent nitrogen oxide idling emissions standard. A heavy-duty } \\
\text { diesel engine certified for optional idling emissions standards must have a } \\
\text { "certified clean idle" label, issued by the engine manufacturer, affixed } \\
\text { permanently on the driver's side hood of the truck. Similarly, off-road diesel } \\
\text { engine APSs fitted with a proper, verified level } 3 \text { diesel particulate filter must } \\
\text { have a "verified clean APS" label, issued by the APS manufacturer, affixed } \\
\text { permanently on the driver's side hood of the truck. Operators of trucks } \\
\text { equipped with sleeper berths are required to shut down the engine manually } \\
\text { when idling more than five minutes at any location within California and are } \\
\text { subject to fines for violation. The California Department of Motor Vehicles } \\
\text { will not register, renew, or transfer registration for any vehicle operator who } \\
\text { has received a violation until the violation is cleared. For more information, } \\
\text { see http://www. arb.ca.gov/msprog/truck-idling/truck-idling.htm. } \\
\text { (Reference California Code of Regulations Title } 13, \text { Section } 2485 \text { ) }\end{array}$ \\
\hline California & $\begin{array}{l}\text { State } \\
\text { Incentive }\end{array}$ & $\begin{array}{l}\text { Emissions Reductions Grants The Carl Moyer Memorial Air Quality } \\
\text { Standards Attainment Program (Program) provides incentives to cover the } \\
\text { incremental cost of purchasing engines and equipment that are cleaner than } \\
\text { required by law. Eligible projects include heavy-duty fleet modernization, } \\
\text { light-duty vehicle replacements and retrofits, idle reduction technology, and } \\
\text { off-road vehicle and equipment purchases. The Program provides funds for } \\
\text { significant near-term reductions in nitrogen oxide emissions, reactive organic } \\
\text { gases, and particulate matter emissions. Funding is available until January } 1 \text {, } \\
\text { 2024. Contact local air districts for more information about grant funding } \\
\text { availability and distribution. Also see http://www.arb.ca.gov/msprog/ } \\
\text { moyer/moyer.htm. (Reference California Health and Safety Code 44275- } \\
44299.2 \text { ) }\end{array}$ \\
\hline California & $\begin{array}{l}\text { State } \\
\text { Incentive }\end{array}$ & $\begin{array}{l}\text { Heavy-Duty Vehicle Emissions Reduction Grants Projects that reduce } \\
\text { emissions from freight movement in the state, including heavy-duty truck } \\
\text { replacement, repower, or retrofit; and truck stop electrification infrastructure } \\
\text { development. For more information about funding application opportunities, } \\
\text { see http://www.arb.ca.gov/bonds/gmbond/gmbond.htm. (Reference } \\
\text { California Health and Safety Code } 39625-39627.5 \text { ) }\end{array}$ \\
\hline California & \begin{tabular}{|l|} 
Laws \& \\
Regulations
\end{tabular} & $\begin{array}{l}\text { Idle Reduction Requirement at Schools A school bus driver must turn } \\
\text { off the engine upon stopping at a school, or within } 100 \text { feet of a school, and } \\
\text { may not turn the engine on more than } 30 \text { seconds before departing from the } \\
\text { location. When the bus is at least } 100 \text { feet away from a school, the driver } \\
\text { may not idle the engine for more than five consecutive minutes, or for } \\
\text { periods totaling more than five minutes during any one hour period. Transit } \\
\text { and commercial vehicle operators may not idle for more than five } \\
\text { consecutive minutes at each stop within } 100 \text { feet of a school, or for periods } \\
\text { totaling more than five minutes during any one hour period. Exemptions } \\
\text { apply for necessary idling while stopped in traffic, at traffic signals, and at } \\
\text { the direction of law enforcement personnel. For more information, see } \\
\text { http://www.arb.ca.gov/ toxics/sbidling/sbidling.htm\# Enforcement. } \\
\text { (Reference California Code of Regulations Title } 13 \text {, Section 2480) }\end{array}$ \\
\hline Colorado & \begin{tabular}{|l} 
State \\
Incentive
\end{tabular} & $\begin{array}{l}\text { Alternative Fuel, Advanced Vehicle, and Idle Reduction Technology } \\
\text { Tax Credit The Colorado Department of Revenue offers the Innovative } \\
\text { Motor Vehicle Credit for a vehicle titled and registered in Colorado that uses } \\
\text { or is converted to use an alternative fuel, is a diesel hybrid electric } \\
\text { vehicle (HEV), is a plug-in hybrid electric vehicle (PHEV), or has its power } \\
\text { source replaced with one that uses an alternative fuel. Electric vehicles (EVs) } \\
\text { and PHEVs must have a maximum speed of at least } 55 \text { miles per hour. }\end{array}$ \\
\hline
\end{tabular}




\begin{tabular}{|c|c|c|}
\hline & & $\begin{array}{l}\text { Qualified idle reduction technologies, aerodynamic technologies, and clean } \\
\text { fuel trailers are also eligible for the tax credit. Credits for vehicles purchased } \\
\text { or converted January } 1,2014 \text {, through December } 31,2021 \text {, are based on } \\
\text { defined vehicle and technology categories as listed below. Credit amounts } \\
\text { vary for each category, vehicle weight, and tax year with percentages } \\
\text { applying to incremental cost for alternative fuel vehicle (AFV), purchases, } \\
\text { and power source replacements. Credit amounts apply to the actual cost for } \\
\text { conversions, idle reduction and aerodynamic technologies, and clean fuel } \\
\text { trailer purchases and conversions, minus any eligible federal credits, grants, } \\
\text { or rebates. Credits for EVs and PHEVs in Category } 1 \text { are equal to the actual } \\
\text { cost incurred to purchase or lease the vehicle, multiplied by the battery } \\
\text { capacity, and divided by } 100 \text {. That amount must be multiplied by a factor to } \\
\text { determine the credit amount, as follows: } 1.0 \text { for } 2014-2018,0.75 \text { for } 2019 \text {, } \\
\text { 0.50 for } 2020, \text { and } 0.25 \text { for } 2021 \text {. Annual credit caps exist for each } \\
\text { technology type and vehicle weight class, and for cumulative annual credits. } \\
\text { A person who claimed a tax credit in previous years for the purchase or lease } \\
\text { of Model Year } 2004 \text { and newer HEV may claim an additional credit for the } \\
\text { conversion of the same vehicle to a PHEV. The purchase of a used vehicle } \\
\text { may qualify if the vehicle was not previously registered in Colorado. Credits } \\
\text { may not be carried forward and a taxpayer will receive a refund for the } \\
\text { excess credit. (Reference Colorado Revised Statutes } 39-22-516.5,39-22- \\
516.7, \text { and } 39-22-516.8 \text { ) }\end{array}$ \\
\hline Colorado & $\begin{array}{l}\text { State } \\
\text { Incentive }\end{array}$ & $\begin{array}{l}\text { Idle Reduction Weight Exemption A commercial vehicle equipped with } \\
\text { qualified idle reduction technology may exceed the state's gross, total axle, } \\
\text { or bridge formula vehicle weight limits by up to } 550 \text { pounds to compensate } \\
\text { for the additional weight of the idle reduction technology. Upon request, } \\
\text { vehicle operators must provide proof that the idle reduction technology is } \\
\text { fully functional. (Reference } 8 \text { Code of Colorado Regulations 1507-28) }\end{array}$ \\
\hline Connecticut & $\begin{array}{l}\text { Laws \& } \\
\text { Regulations }\end{array}$ & $\begin{array}{l}\text { Idle Reduction Requirement School bus operators may not idle a school } \\
\text { bus engine for more than three consecutive minutes except under the } \\
\text { following conditions: uncontrollable traffic conditions or mechanical } \\
\text { difficulties; operation of heating, cooling, safety or auxiliary equipment; } \\
\text { outdoor temperatures below } 20 \text { degrees Fahrenheit; maintenance of a safe } \\
\text { temperature for students with special needs; school bus repair; or receipt } \\
\text { or discharge of passengers on a public highway or road. (Reference } \\
\text { Connecticut General Statutes } 14-277 \text { ) }\end{array}$ \\
\hline Connecticut & $\begin{array}{l}\text { State } \\
\text { Incentive }\end{array}$ & $\begin{array}{l}\text { Idle Reduction Weight Exemption A commercial vehicle equipped with } \\
\text { idle reduction technology may exceed the state's gross, total axle, total } \\
\text { tandem, or bridge formula vehicle weight limits by up to } 400 \text { pounds to } \\
\text { compensate for the additional weight of the idle reduction technology. The } \\
\text { additional weight may not exceed the actual weight of the idle reduction } \\
\text { unit. (Reference Connecticut General Statutes } 14-267 \text { c) }\end{array}$ \\
\hline Delaware & $\begin{array}{l}\text { State } \\
\text { Incentive }\end{array}$ & $\begin{array}{l}\text { Idle Reduction Weight Exemption Any motor vehicle equipped with } \\
\text { qualified idle reduction technology may exceed the state gross, axle, } \\
\text { tandem, or bridge weight limits by up to } 400 \text { pounds to account for the } \\
\text { weight of the technology. The additional weight may not exceed the actual } \\
\text { weight of the idle reduction unit. To qualify for the exemption, the vehicle } \\
\text { operator must also be able to prove the weight of the idle reduction } \\
\text { technology and demonstrate that the technology is fully functional. } \\
\text { (Reference Delaware Code Title } 21 \text {, Chapter } 45 \text {, Section } 4503 \text { f) }\end{array}$ \\
\hline Delaware & \begin{tabular}{|l} 
Laws \& \\
Regulations
\end{tabular} & $\begin{array}{l}\text { Idle Reduction Requirement On-road heavy-duty motor vehicles with a } \\
\text { gross vehicle weight rating of } 8,500 \text { pounds or greater may not idle for more } \\
\text { than three consecutive minutes when the vehicle is stationary. Violators are } \\
\text { subject to penalties of up to } \$ 500 \text { for each offense. Heavy-duty vehicles } \\
\text { subject to this regulation include long- haul and delivery trucks as well as } \\
\text { transit and school buses. Emergency fire, rescue, and lifesaving vehicles are } \\
\text { exempt. Other vehicle operating situations may also fall under the }\end{array}$ \\
\hline
\end{tabular}




\begin{tabular}{|c|c|c|}
\hline & & $\begin{array}{l}\text { exemption section of the regulation. (Reference Delaware Department of } \\
\text { Natural Resources and Environmental Control Regulation 1145) }\end{array}$ \\
\hline $\begin{array}{l}\text { District of } \\
\text { Columbia }\end{array}$ & $\begin{array}{l}\text { Laws \& } \\
\text { Regulations }\end{array}$ & $\begin{array}{l}\text { Idle Reduction Requirement } \\
\text { A diesel- or gasoline-powered motor vehicle may not idle for more than } \\
\text { three consecutive minutes, except under the following conditions: 1) to } \\
\text { operate power takeoff equipment including, but not limited to, cement } \\
\text { mixers, refrigeration systems, and delivery vehicles; } 2 \text { ) to operate private } \\
\text { passenger vehicles; or } 3 \text { ) to operate heating equipment for five minutes } \\
\text { when the ambient temperature is } 32 \text { degrees Fahrenheit or below. } \\
\text { (Reference District of Columbia Municipal Regulations Title 20, Chapter 9, } \\
\text { Section 900.1) }\end{array}$ \\
\hline Florida & $\begin{array}{l}\text { State } \\
\text { Incentive }\end{array}$ & $\begin{array}{l}\text { Idle Reduction Weight Exemption Any motor vehicle equipped with idle } \\
\text { reduction technology may exceed the gross vehicle or internal bridge weight } \\
\text { by the amount equal to the certified weight of the idle reduction technology, } \\
\text { up to } 550 \text { pounds. To be eligible, the operator must present written } \\
\text { verification of the weight of the idle reduction technology and demonstrate } \\
\text { that it is fully functional at all times. (Reference Florida Statutes } 316.545 \text { ) }\end{array}$ \\
\hline Georgia & $\begin{array}{l}\text { State } \\
\text { Incentive }\end{array}$ & $\begin{array}{l}\text { Emissions Reduction Tax Credit An income tax credit is available to } \\
\text { individuals who install eligible diesel particulate emissions reduction } \\
\text { equipment at any truck stop, depot, or other facility. The amount of the tax } \\
\text { credit is equal to } 10 \% \text { of the total equipment and installation costs and is } \\
\text { allowed for the taxable year in which the taxpayer first places the } \\
\text { equipment in use. The equipment must meet Georgia Regional } \\
\text { Transportation Authority standards and must provide for heat, air } \\
\text { conditioning, light, and communications for the driver's compartment of a } \\
\text { heavy-duty commercial motor vehicle parked at a truck stop, depot, or } \\
\text { other facility. The use of the technology must enable the driver to turn off } \\
\text { the vehicle's engine, with a corresponding reduction of particulate } \\
\text { emissions. (Reference Georgia Code } 48-7-40.19 \text { ) }\end{array}$ \\
\hline Georgia & $\begin{array}{l}\text { State } \\
\text { Incentive }\end{array}$ & $\begin{array}{l}\text { Idle Reduction Weight Exemption Any motor vehicle equipped with idle } \\
\text { reduction technology may exceed the state gross, axle, and tandem weight } \\
\text { limits by up to } 400 \text { pounds to account for the weight of the technology. To } \\
\text { be eligible for the weight exemption, the vehicle operator must be able to } \\
\text { present written certification of the weight of the idle reduction technology } \\
\text { and demonstrate or certify that the technology is fully functional at all } \\
\text { times. (Reference Georgia Code } 32-6-27 \text { ) }\end{array}$ \\
\hline Hawaii & $\begin{array}{l}\text { Laws \& } \\
\text { Regulations }\end{array}$ & $\begin{array}{l}\text { Idle Reduction Requirement A vehicle may not idle at a loading zone, } \\
\text { parking or service area, route terminal, or other off-street areas, except for } \\
\text { the following situations: during adjustment or repair of the engine; during } \\
\text { auxiliary equipment operation such as operation of cranes and certain bulk } \\
\text { carriers, provided no visible smoke is emitted and the equipment is being } \\
\text { used for its intended purpose; during loading and unloading of passengers, } \\
\text { not to exceed three minutes; and during engine start-up and cool-down, } \\
\text { not to exceed three minutes. (Reference Hawaii Administrative Rules Title } \\
11 \text {, Chapter 60.1-34) }\end{array}$ \\
\hline Illinois & $\begin{array}{l}\text { State } \\
\text { Incentive }\end{array}$ & $\begin{array}{l}\text { School Bus Retrofit Reimbursement The Illinois Department of } \\
\text { Education will reimburse any qualifying school district for the cost of } \\
\text { converting gasoline buses to more fuel-efficient engines or to engines using } \\
\text { alternative fuels. Restrictions may apply. (Reference } 105 \text { Illinois Compiled } \\
\text { Statutes 5/29-5) }\end{array}$ \\
\hline Illinois & $\begin{array}{l}\text { State } \\
\text { Incentive }\end{array}$ & $\begin{array}{l}\text { Clean Diesel Retrofit and Idle Reduction Grants The Illinois Clean } \\
\text { Diesel Grant Program (Program) provides funding to local governments, } \\
\text { school districts, school bus companies, colleges, universities, mass transit } \\
\text { districts, businesses, truck owners/operators, and non-profit organizations } \\
\text { for the installation of diesel oxidation catalysts, closed crankcase ventilation } \\
\text { systems, particulate matter filters, and anti-idling equipment, including } \\
\text { direct- fired heaters and auxiliary power units. In addition, funding may be } \\
\text { available for diesel-electric hybrid vehicles. The Program is part of the }\end{array}$ \\
\hline
\end{tabular}




\begin{tabular}{|c|c|c|}
\hline & & $\begin{array}{l}\text { Illinois Green Fleets Program, which targets school buses, shuttle buses, } \\
\text { diesel vehicles operating in residential areas, and over-the-road trucks } \\
\text { located and spending significant driving time in Illinois. For more } \\
\text { information, see http://www. illinoisgreenfleets.org/. }\end{array}$ \\
\hline Illinois & $\begin{array}{l}\text { Laws \& } \\
\text { Regulations }\end{array}$ & $\begin{array}{l}\text { Fuel-Efficient Vehicle Acquisition Goals Illinois state agencies must } \\
\text { work towards meeting the following goals: By July } 1,2015 \text {, at least } 20 \% \text { of } \\
\text { new passenger vehicles purchased must be hybrid electric vehicles (HEVs) } \\
\text { and } 5 \% \text { must be battery electric vehicles (EVs); by July } 1,2025 \text {, at least } \\
60 \% \text { of new passenger vehicles purchased must be HEVs and } 15 \% \text { must be } \\
\text { EVs. Agencies that operate medium- and heavy-duty vehicles must } \\
\text { implement strategies to reduce fuel consumption through diesel emission } \\
\text { control devices, HEV and EVs technologies, alternative fuel use, and fuel- } \\
\text { efficient technologies. Agencies must also implement strategies to promote } \\
\text { the use of biofuels in state vehicles; reduce the environmental impacts of } \\
\text { employee travel; and encourage employees to adopt alternative travel } \\
\text { methods, such as carpooling. (Reference Executive Order } 11,2009 \text { ) }\end{array}$ \\
\hline Illinois & $\begin{array}{l}\text { State } \\
\text { Incentive }\end{array}$ & $\begin{array}{l}\text { Idle Reduction Weight Exemption A vehicle equipped with idle reduction } \\
\text { technology may exceed the state's gross, axle, and bridge vehicle weight } \\
\text { limits by up to } 400 \text { pounds to compensate for the additional weight of the } \\
\text { idle reduction technology. The additional weight may not exceed the actual } \\
\text { weight of the idle reduction unit. The vehicle operator must carry written } \\
\text { certification showing the weight of the technology and must be able to } \\
\text { demonstrate or certify that the unit is fully functional. (Reference } 625 \text { Illinois } \\
\text { Compiled Statutes 5/15-112) }\end{array}$ \\
\hline Illinois & $\begin{array}{l}\text { Laws \& } \\
\text { Regulations }\end{array}$ & $\begin{array}{l}\text { Idle Reduction Requirement A person that operates a diesel powered } \\
\text { motor vehicle in certain counties and townships may not cause or allow the } \\
\text { motor vehicle, when it is not in motion, to idle for more than a total of } 10 \\
\text { minutes within any one-hour period. If the vehicle is waiting to weigh, load, } \\
\text { or unload cargo or freight, it may idle for up to } 30 \text { minutes within any one- } \\
\text { hour period. Specified areas include the counties of Cook, DuPage, Lake, } \\
\text { Kane, McHenry, Will, Madison, St. Clair, and Monroe, and the townships of } \\
\text { Oswego (Kendall County) and Aux Sable and Goose Lake (Grundy County). } \\
\text { Exceptions apply, including those pertaining to emergency vehicles, vehicle } \\
\text { weight, traffic, auxiliary power unit use, and outside temperature. } \\
\text { (Reference } 625 \text { Illinois Compiled Statutes 5/11-1429) }\end{array}$ \\
\hline Indiana & $\begin{array}{l}\text { Laws \& } \\
\text { Regulations }\end{array}$ & $\begin{array}{l}\text { Alternative Fuel and Special Fuel Definitions The definition of } \\
\text { alternative fuel includes liquefied petroleum gas (propane). Special fuel is } \\
\text { defined as all combustible gases and liquids that are suitable for powering an } \\
\text { internal combustion engine or motor or are used exclusively for heating, } \\
\text { industrial, or farm purposes. Special fuels include biodiesel, blended } \\
\text { biodiesel, and natural gas products, including liquefied and compressed } \\
\text { natural gas, and combinations of propane and compressed natural gas. } \\
\text { (Reference Indiana Code } 6-6-2.5-1 \text { and } 6-6-2.5-22 \text { ) }\end{array}$ \\
\hline Indiana & $\begin{array}{l}\text { State } \\
\text { Incentive }\end{array}$ & $\begin{array}{l}\text { Diesel Vehicle Retrofit and Improvement Grants The Indiana } \\
\text { Department of Environmental Management (IDEM) administers two } \\
\text { DieselWise Indiana grant programs to support projects that reduce diesel } \\
\text { emissions. The Clean Diesel Across Northern Indiana program provides } \\
\text { grants ranging from } \backslash \$ 25,000 \text { to } \backslash \$ 200,000 \text { for projects in the Gary, } \\
\text { Hammond, Michigan City, South Bend, Elkhart, and Fort Wayne areas. The } \\
\text { Clean Diesel Across Indiana program provides grants ranging from } \backslash \$ 10,000 \\
\text { to } \backslash \$ 75,000 \text { for projects in central and south Indiana. Eligible applicants } \\
\text { include private and public entities that operate equipment serving the public, } \\
\text { including private bus fleets and sanitation fleets. Eligible projects include } \\
\text { replacing or converting a diesel vehicle or vehicle component with one that } \\
\text { operates on alternative fuel, as well as installing exhaust retrofit } \\
\text { technologies, idle reduction technologies, aerodynamic technologies, and low } \\
\text { rolling resistance tires. For more information, see http://www.in.gov/ } \\
\text { idem/airquality/2561.htm. }\end{array}$ \\
\hline
\end{tabular}




\begin{tabular}{|c|c|c|}
\hline Indiana & \begin{tabular}{|l} 
Laws \& \\
Regulations
\end{tabular} & $\begin{array}{l}\text { Vehicle Idling Policy Requirements Schools must adopt and enforce a } \\
\text { written policy to address idling vehicles on school grounds. This policy must } \\
\text { be modeled after the Indiana State Department of Health's manual of best } \\
\text { practices for managing indoor air quality in schools and must be available for } \\
\text { review. (Reference Indiana Administrative Code } 410 \text { IAC } 33-4-3 \text { ) }\end{array}$ \\
\hline Kansas & \begin{tabular}{|l|} 
State \\
Incentive
\end{tabular} & $\begin{array}{l}\text { Idle Reduction Weight Exemption Any vehicle or combination of vehicles } \\
\text { equipped with idle reduction technology may exceed the state's gross and } \\
\text { axle weight limits by up to } 400 \text { pounds to compensate for the additional } \\
\text { weight of the idle reduction technology. (Reference Kansas Statutes 8-1908, } \\
8-1909 \text {, and 8-1917) }\end{array}$ \\
\hline Maine & $\begin{array}{l}\text { State } \\
\text { Incentive }\end{array}$ & $\begin{array}{l}\text { Idle Reduction Weight Exemption Any vehicle equipped with a qualified } \\
\text { auxiliary power unit (APU) may exceed the state's gross vehicle and axle } \\
\text { weight limits by up to } 400 \text { pounds to compensate for the additional weight of } \\
\text { the APU. (Reference Maine Revised Statutes Title 29-A, Section 2360) }\end{array}$ \\
\hline Maine & \begin{tabular}{|l} 
Laws \& \\
Regulations
\end{tabular} & $\begin{array}{l}\text { Idle Reduction Requirement A commercial vehicle or gasoline powered } \\
\text { vehicle may not idle for more than five minutes during any } 60 \text {-minute } \\
\text { period. Exemptions are allowed for the following: } 1 \text { ) a vehicle stopped in } \\
\text { traffic or at the direction of a law enforcement official; } 2 \text { ) a vehicle needing } \\
\text { auxiliary power for equipment or for climate control to prevent a safety or } \\
\text { health emergency; } 3 \text { ) a vehicle being inspected by a state or federal motor } \\
\text { vehicle inspector; 4) an emergency vehicle being used in the course of } \\
\text { official business; 5) a commercial vehicle using air conditioning or heating } \\
\text { during a driver rest period or while waiting to load or unload; and } 6 \text { ) when } \\
\text { the ambient outside air temperature is less than zero degrees Fahrenheit. } \\
\text { When the outside ambient air temperature is between zero and } 32 \text { degrees } \\
\text { Fahrenheit, vehicles may idle for up to } 15 \text { minutes during a } 60 \text {-minute } \\
\text { period. In addition, a passenger bus my idle for up to } 15 \text { minutes during a } \\
\text { 60-minute period while passengers are on board. Any owner of a location } \\
\text { that is used for loading and unloading of commercial vehicles may not } \\
\text { require that vehicles idle for periods longer than } 30 \text { minutes while waiting } \\
\text { to load or unload at the location. Violators are subject to fines. (Reference } \\
\text { Maine Revised Statutes Title } 38 \text {, Section } 585-L \text { ) }\end{array}$ \\
\hline Maryland & \begin{tabular}{|l} 
State \\
Incentive
\end{tabular} & $\begin{array}{l}\text { Idle Reduction Weight Exemption Any motor vehicle equipped with a } \\
\text { qualified auxiliary power unit (APU) or idle reduction technology may } \\
\text { exceed the state gross, axle, tandem, or bridge weight limits by up to } 550 \\
\text { pounds to account for the weight of the technology. The additional weight } \\
\text { may not exceed the actual weight of the idle reduction unit. The vehicle } \\
\text { operator must be able to provide written certification of the weight of the } \\
\text { APU or idle reduction technology, and demonstrate that the technology is } \\
\text { fully functional. (Reference Maryland Statutes, Transportation Code 24-109) }\end{array}$ \\
\hline Maryland & $\begin{array}{l}\text { State } \\
\text { Incentive }\end{array}$ & $\begin{array}{l}\text { Innovative Transportation Project Competitive Grant Program The } \\
\text { Maryland Energy Administration (MEA) provides funds to deploy "game } \\
\text { changing" or innovative transportation projects that increase the use of } \\
\text { alternative fuel vehicles, such as workplace charging. Projects must be } \\
\text { located in Maryland and have the potential to significantly advance the } \\
\text { clean energy market through commercially available technologies. Projects } \\
\text { can include clean energy conversion technologies, systems, or applications } \\
\text { used in other states or regions of the world, but not commonly used in } \\
\text { Maryland. Grant awards are available for up to } 30 \% \text { of the total project } \\
\text { cost with individual awards ranging from } \$ 50,000 \text { to } \$ 250,000 \text {. The } \\
\text { program is not currently funded (verified May } 2015 \text { ). For more } \\
\text { information, including program application and award requirements, see } \\
\text { http://energy.maryland.gov/Business/gamechanger/index.html. }\end{array}$ \\
\hline Maryland & $\begin{array}{l}\text { Laws \& } \\
\text { Regulations }\end{array}$ & $\begin{array}{l}\text { Idle Reduction Requirement A motor vehicle engine may not operate } \\
\text { for more than five consecutive minutes when the vehicle is not in motion, } \\
\text { with the following exceptions: } 1 \text { ) when traffic conditions or mechanical } \\
\text { difficulties do not allow the vehicle to operate; } 2 \text { ) when it is necessary to } \\
\text { operate heating, cooling or auxiliary equipment installed on the vehicle; } 3 \text { ) }\end{array}$ \\
\hline
\end{tabular}




\begin{tabular}{|c|c|c|}
\hline & & $\begin{array}{l}\text { to bring vehicle to manufacturer's recommended operating temperature; } \\
\text { or } 4 \text { ) if idling is necessary to accomplish the intended use of the vehicle. } \\
\text { (Reference Maryland Statutes, Transportation Code 22-402) }\end{array}$ \\
\hline Maryland & \begin{tabular}{|l} 
State \\
Incentive
\end{tabular} & $\begin{array}{l}\text { Idle Reduction Technology Grant Program The Maryland Energy } \\
\text { Administration (MEA) administers the Maryland Idle Reduction Technology } \\
\text { Grant Program, which provides grants to motor carriers for the purchase } \\
\text { and installation of qualified idle reduction technology on on-highway class } \\
6 \text { to class } 8 \text { trucks registered in Maryland. Leased vehicles are also eligible. } \\
\text { Idle reduction technologies must be verified by the U.S. Environmental } \\
\text { Protection Agency (EPA) or California Air Resources Board (CARB). Awards } \\
\text { are limited to } 50 \% \text { of the installed cost, up to } \$ 3,500 \text {. A single motor } \\
\text { carrier may receive up to } 10 \text { grants. MEA must receive grant applications } \\
\text { by September } 1,2014 \text {. Funding is currently not available for this program } \\
\text { (verified April 2015). For more information about the grant program, } \\
\text { including how to apply, see http://energy.maryland.gov/Transportation/ } \\
\text { idle/index.html. }\end{array}$ \\
\hline Massachusetts & \begin{tabular}{|l} 
State \\
Incentive
\end{tabular} & $\begin{array}{l}\text { Alternative Fuel Vehicle and Infrastructure Grants The } \\
\text { Massachusetts Department of Energy Resources' Clean Vehicle Project } \\
\text { offers grant funding for public and private fleets to purchase alternative } \\
\text { fuel vehicles and infrastructure, as well as idle reduction technology. } \\
\text { Eligible vehicles include those fueled by natural gas, propane, and } \\
\text { electricity, including hybrid electric, solar electric, and hydraulic hybrid } \\
\text { vehicles. Eligible infrastructure includes natural gas fueling stations and } \\
\text { electric vehicle supply equipment. For information about how to apply for } \\
\text { funding, visit http://www.mass.gov/eea/energy-utilities- clean- } \\
\text { tech/alternative-transportation/clean-cities-coalition.html. }\end{array}$ \\
\hline Massachusetts & \begin{tabular}{|l} 
Laws \& \\
Regulations
\end{tabular} & $\begin{array}{l}\text { Idle Reduction Requirement A motor vehicle may not idle for more } \\
\text { than five consecutive minutes. This regulation does not apply to: } 1 \text { ) } \\
\text { vehicles being serviced, provided that operation of the engine is essential } \\
\text { to the repair; } 2 \text { ) vehicles delivering or accepting goods or merchandise for } \\
\text { which engine assisted power is necessary and substitute alternate power } \\
\text { cannot be made available; or } 3 \text { ) vehicles requiring auxiliary power for an } \\
\text { associate power need other than movement that cannot be substituted by } \\
\text { an alternate power source provided that such operation does not cause or } \\
\text { contribute to air pollution. Violators are subject to fines. Local boards of } \\
\text { health, local police, and state and federal officials may enforce the state } \\
\text { anti-idling law. (Reference Massachusetts General Laws, Chapter } 90 \text {, } \\
\text { Section } 16 \mathrm{~A}, \text { and Department of Environmental Protection Regulations } 310 \\
\text { CMR 7.11(1)(b)) }\end{array}$ \\
\hline Massachusetts & \begin{tabular}{|l} 
State \\
Incentive
\end{tabular} & $\begin{array}{l}\text { Idle Reduction Weight Exemption Any motor vehicle equipped with } \\
\text { qualified idle reduction technology may exceed the state gross, axle, } \\
\text { tandem, or bridge weight limits by up to } 400 \text { pounds to account for the } \\
\text { weight of the technology. The idle reduction technology must be able to } \\
\text { provide electrical service, heating, or cooling to the vehicle. The additional } \\
\text { weight may not exceed the actual weight of the idle reduction unit. The } \\
\text { vehicle operator must also be able to prove the weight of the idle reduction } \\
\text { technology and demonstrate that the technology is fully functional. } \\
\text { (Reference Massachusetts Session Laws, Chapter 165, Section 126, } \\
2014 \text { ) }\end{array}$ \\
\hline Minnesota & \begin{tabular}{|l} 
Laws \& \\
Regulations
\end{tabular} & $\begin{array}{l}\text { State Agency Sustainability Plan and Requirements State agencies } \\
\text { must establish interagency teams to develop and implement sustainability } \\
\text { goals that reduce state vehicle petroleum consumption. In addition, each } \\
\text { state department or agency must prepare an annual sustainability plan that } \\
\text { includes ways to modify vehicle use practices and report annually on } \\
\text { progress towards implementing their plan. Each state agency plan must be } \\
\text { based on following targets and mandates: When reasonably possible, state } \\
\text { agencies must purchase on-road vehicles that use alternative fuels, } \\
\text { including biodiesel blends of } 20 \% \text { (B20) or greater, compressed or liquefied }\end{array}$ \\
\hline
\end{tabular}




\begin{tabular}{|c|c|c|}
\hline & & $\begin{array}{l}\text { natural gas, ethanol blends of } 70 \% \text { (E70) or greater, hydrogen, propane, or } \\
\text { electricity, or (with the exception of buses, snowplows, and construction } \\
\text { vehicles) have a fuel economy rating that exceeds } 30 \text { miles per gallon } \\
\text { (mpg) in the city and } 35 \mathrm{mpg} \text { on the highway; when reasonably possible, } \\
\text { state employees must fuel vehicles capable of operating on an alternative } \\
\text { fuel with that fuel; State agencies must increase the use of renewable fuels } \\
\text { derived from agricultural products or waste products; and State agencies } \\
\text { must increase the use of technology for delivering information and services } \\
\text { To reduce reliance on the state's fleet. (Reference Executive Order } 11-13 \text {, } \\
2011 \text {, and Minnesota Statutes } 16 \mathrm{C} .135 \text { and 16C.137) }\end{array}$ \\
\hline Minnesota & $\begin{array}{l}\text { State } \\
\text { Incentive }\end{array}$ & $\begin{array}{l}\text { Idle Reduction Weight Exemption A motor vehicle equipped with idle } \\
\text { reduction or emissions reduction technology may exceed the maximum } \\
\text { gross vehicle weight and axle weight limits by up to } 550 \text { pounds to } \\
\text { compensate for the additional weight of the technology. The vehicle } \\
\text { operator must provide documentation that the qualified equipment is } \\
\text { installed on the vehicle. (Reference Senate File } 1270,2013 \text {, and Minnesota } \\
\text { Statutes } 169.824 \text { ) }\end{array}$ \\
\hline Minnesota & \begin{tabular}{|l} 
State \\
Incentive
\end{tabular} & $\begin{array}{l}\text { Idle Reduction Technology Loan Program The Minnesota Pollution } \\
\text { Control Agency's Small Business Environmental Improvement and } \\
\text { Auxiliary Power Unit Loan Programs provide low-interest loans up to } \\
\$ 50,000 \text { to qualified small businesses to finance environmental projects } \\
\text { such as capital equipment upgrades that meet or exceed environmental } \\
\text { regulations, including idle reduction technologies. For more information, } \\
\text { see the Small Business Auxiliary Power Unit Loan Program website } \\
\text { (http://www.pca.state.mn.us/index.php/topics/small-business- } \\
\text { environmental-assistance- program/small-business-ombudsman/small- } \\
\text { business-auxiliarv-Dower-unit-apu-loan-proaram.html). }\end{array}$ \\
\hline Mississippi & \begin{tabular}{|l} 
Laws \& \\
Regulations
\end{tabular} & $\begin{array}{l}\text { School Bus Idle Reduction Requirement The Mississippi State } \\
\text { Department of Education requires public school district bus operators to } \\
\text { minimize school bus idling to reduce exposure to diesel exhaust. (Reference } \\
\text { Mississippi Code } 37-11-71 \text { ) }\end{array}$ \\
\hline Missouri & \begin{tabular}{|l} 
State \\
Incentive
\end{tabular} & $\begin{array}{l}\text { Idle Reduction Weight Exemption Any vehicle equipped with qualified } \\
\text { idle reduction technology may exceed the state's gross and axle weight } \\
\text { limits by up to } 400 \text { pounds to compensate for the additional weight of the } \\
\text { idle reduction technology. The vehicle operator must be able to provide } \\
\text { proof of the weight of the idle reduction technology and that it is fully } \\
\text { functional at all times. (Reference Missouri Revised Statutes } 304.180 \text { ) }\end{array}$ \\
\hline Nebraska & $\begin{array}{l}\text { State } \\
\text { Incentive }\end{array}$ & $\begin{array}{l}\text { Idle Reduction Weight Exemption The maximum gross weight limit and } \\
\text { axle weight limit for any vehicle or combination of vehicles equipped with } \\
\text { idle reduction technology may exceed the state's gross weight limit by up to } \\
400 \text { pounds per vehicle to compensate for the additional weight of the idle } \\
\text { reduction technology. (Reference Nebraska Revised Statutes } 60-6,294 \text { ) }\end{array}$ \\
\hline Nevada & $\begin{array}{l}\text { Laws \& } \\
\text { Regulations }\end{array}$ & $\begin{array}{l}\text { Idle Reduction Requirement Diesel truck or bus engines may not idle } \\
\text { for more than } 15 \text { consecutive minutes. Exemptions apply to diesel trucks or } \\
\text { buses for which the Nevada State Environmental Commission has issued a } \\
\text { variance from this requirement, or diesel trucks and buses that are } \\
\text { emergency vehicles; are used for removal of snow or to repair or maintain } \\
\text { other vehicles; are stopped due to traffic congestion; are undergoing repair } \\
\text { or maintenance; produce emissions contained and treated according to } \\
\text { State Environmental Commission methods; or must idle to perform a } \\
\text { specific task. (Reference Nevada Administrative Code 445B.576) }\end{array}$ \\
\hline $\begin{array}{l}\text { New } \\
\text { Hampshire }\end{array}$ & $\begin{array}{l}\text { Laws \& } \\
\text { Regulations }\end{array}$ & $\begin{array}{l}\text { School District Emissions Reduction Policies Each school district must } \\
\text { develop and implement a policy to minimize or eliminate emissions from } \\
\text { buses, cars, delivery vehicles, maintenance vehicles, and other motor } \\
\text { vehicles used on school property. Policies must take into account existing } \\
\text { anti-idling and clean air zone regulations that the New Hampshire } \\
\text { Department of Environmental Services established. (Reference New } \\
\text { Hampshire Revised) }\end{array}$ \\
\hline
\end{tabular}




\begin{tabular}{|c|c|c|}
\hline $\begin{array}{l}\text { New } \\
\text { Hampshire }\end{array}$ & \begin{tabular}{|l} 
State \\
Incentive
\end{tabular} & $\begin{array}{l}\text { Idle Reduction Weight Exemption Any heavy-duty vehicle equipped } \\
\text { with an auxiliary power unit or other qualified idle reduction technology } \\
\text { may exceed the state gross, axle, tandem, or bridge formula weight limits } \\
\text { by up to } 550 \text { pounds. To qualify for this exemption, drivers must be able to } \\
\text { provide proof of the idle reduction technology's weight through written } \\
\text { certification. Drivers must also be able to prove through demonstration or } \\
\text { certification that the idle reduction technology is fully functional at all } \\
\text { times. (Reference New Hampshire Revised Statutes } 266: 18-c)\end{array}$ \\
\hline $\begin{array}{l}\text { New } \\
\text { Hampshire }\end{array}$ & \begin{tabular}{|l|} 
Laws \& \\
Regulations
\end{tabular} & $\begin{array}{l}\text { State Energy Strategy Development The New Hampshire Office of } \\
\text { Energy Planning, in consultation with the New Hampshire Energy Advisory } \\
\text { Council, prepared a } 10 \text {-year energy strategy for the state. Among other } \\
\text { issues, the strategy addresses the impact of transportation policies and } \\
\text { programs on electricity energy needs in the state. The recommendations in } \\
\text { the strategy include enabling and encouraging adoption of plug-in electric } \\
\text { vehicles, and reducing unnecessary idling. For more information, including } \\
\text { the final strategy, visit http://www.nh.gov/oep/energy/programs/ } \\
\text { SB191.htm. (Reference Senate Bill 191, 2013) }\end{array}$ \\
\hline $\begin{array}{l}\text { New } \\
\text { Hampshire }\end{array}$ & \begin{tabular}{|l|} 
Laws \& \\
Regulations
\end{tabular} & $\begin{array}{l}\text { Idle Reduction Requirement The owner or operator of a diesel powered } \\
\text { vehicle must limit the length of time their vehicle remains idle. The limit is } \\
\text { based on the outside temperature, as follows: Above } 32 \text { degrees } \\
\text { Fahrenheit, } 5 \text { minute limit; between } 32 \text { and }-10 \text { degrees Fahrenheit, } 15 \\
\text { minute limit; below - } 10 \text { degrees Fahrenheit, no limit. Certain vehicles are } \\
\text { exempt from the regulation, including vehicles in traffic, emergency } \\
\text { vehicles, vehicles providing power take-off for refrigeration or lift gate } \\
\text { pumps, vehicles idling for required maintenance or diagnostic purposes, } \\
\text { and vehicles supplying heat or air conditioning for passenger comfort } \\
\text { during transportation. (Reference [New Hampshire Department of } \\
\text { Environmental Services, Administrative Rules Env-A } 1101.05 \text { and 1101.06) }\end{array}$ \\
\hline New Jersey & \begin{tabular}{|l|} 
Laws \& \\
Regulations
\end{tabular} & $\begin{array}{l}\text { Idle Reduction Requirement A gasoline-fueled motor vehicle is not } \\
\text { allowed to operate for more than three consecutive minutes when the } \\
\text { vehicle is not in motion, with the following exceptions: } 1 \text { ) a vehicle stopped } \\
\text { in a line of traffic; 2) a vehicle being inspected by a state or federal motor } \\
\text { vehicle inspector; } 3 \text { ) an emergency vehicle operating in an emergency } \\
\text { situation; 4) a vehicle being repaired or serviced; 5) a vehicle whose } \\
\text { primary power source is used for a mechanical operation other than } \\
\text { propulsion; and 6) a vehicle parked in a non-residentially zoned area with } \\
\text { a sleeper berth being used for sleeping or resting. A gasoline bus loading } \\
\text { or unloading passengers may idle for } 15 \text { consecutive minutes in a } 60- \\
\text { minute period. A diesel-fueled motor vehicle is not allowed to operate for } \\
\text { more than three consecutive minutes when the vehicle is not in motion. If } \\
\text { the vehicle is not in a parking space equipped with idle reduction } \\
\text { electrification technology, the following exceptions apply: } 1 \text { ) a vehicle } \\
\text { stopped in a line of traffic; } 2 \text { ) a vehicle whose primary power source is } \\
\text { used for a mechanical operation other than propulsion; } 3 \text { ) a vehicle being } \\
\text { inspected by a state or federal motor vehicle inspector; } 4 \text { ) an emergency } \\
\text { vehicle operating in an emergency situation; } 5 \text { ) a vehicle being repaired or } \\
\text { serviced; } 6 \text { ) a vehicle with a sleeper berth that is equipped with a Model } \\
\text { Year } 2007 \text { or newer engine and/or a functioning diesel particulate filter; } \\
\text { and } 7 \text { ) a vehicle that uses a technology designed to reduce engine idling, } \\
\text { such as auxiliary or alternate power units, generator sets, or bunk heaters. } \\
\text { Additionally, diesel vehicles may idle for } 15 \text { consecutive minutes when the } \\
\text { vehicle's engine has been stopped for at least three hours if the } \\
\text { temperature is below } 25 \text { degrees Fahrenheit, and a diesel bus loading or } \\
\text { unloading passengers may idle for } 15 \text { consecutive minutes in a } 60 \text {-minute } \\
\text { period. Violators will be issued fines. (Reference New Jersey Administrative } \\
\text { Code } 7: 27-14.3 \text { and } 7: 27-15.8 \text { ) }\end{array}$ \\
\hline
\end{tabular}




\begin{tabular}{|c|c|c|}
\hline New Mexico & \begin{tabular}{|l} 
State \\
Incentive
\end{tabular} & $\begin{array}{l}\text { Idle Reduction Weight Exemption Any vehicle or combination of } \\
\text { vehicles equipped with idle reduction technology may exceed the state's } \\
\text { gross and axle weight limits by up to } 400 \text { pounds to compensate for the } \\
\text { additional weight of the idle reduction technology. (Reference New Mexico } \\
\text { Statutes } 66-7-410 \text { ) }\end{array}$ \\
\hline New York & \begin{tabular}{|l} 
State \\
Incentive
\end{tabular} & $\begin{array}{l}\text { Idle Reduction Weight Exemption Any motor vehicle equipped with } \\
\text { qualified idle reduction technology may exceed the state's vehicle weight } \\
\text { limits by up to } 400 \text { pounds to compensate for the additional weight of the } \\
\text { idle reduction technology. The vehicle's operator must maintain written } \\
\text { certification of the device's weight and proof that it is fully functional and } \\
\text { must provide this proof to a law enforcement officer upon request. } \\
\text { (Reference New York Vehicle and Traffic Law 385) }\end{array}$ \\
\hline New York & \begin{tabular}{|l} 
Laws \& \\
Regulations
\end{tabular} & $\begin{array}{l}\text { Heavy-Duty Idle Reduction Requirement Heavy-duty vehicles with a } \\
\text { gross vehicle weight rating greater than } 8,500 \text { pounds may not idle for } \\
\text { more than five consecutive minutes when the vehicle is not in motion. } \\
\text { Exceptions apply, including when idling is necessary due to traffic } \\
\text { conditions; to maintain temperatures (under regulation) for passenger } \\
\text { comfort; to provide auxiliary power or for maintenance purposes; to } \\
\text { recharge batteries in hybrid electric vehicles; and for emergency service } \\
\text { vehicles. (Reference New York State Department of Environmental } \\
\text { Conservation Regulations Chapter III, Subpart 217-3) }\end{array}$ \\
\hline New York & \begin{tabular}{|l} 
Laws \& \\
Regulations
\end{tabular} & $\begin{array}{l}\text { School Bus Idle Reduction Policy School bus drivers or drivers of other } \\
\text { vehicles that the school district owns, leases, or contracts must turn off the } \\
\text { vehicle engine while loading or unloading passengers on school grounds or } \\
\text { near a school. Exceptions include idling for mechanical work, to maintain a } \\
\text { comfortable temperature in the vehicle, or in emergency evacuations where } \\
\text { it is necessary to operate wheelchair lifts. Drivers should also instruct pupils } \\
\text { on the necessity to load and unload promptly, park their vehicles diagonally } \\
\text { to minimize exhaust from entering another bus or the school, and turn off } \\
\text { their vehicle during sporting or other events. School districts must provide } \\
\text { personnel with a notice outlining these provisions no later than five days } \\
\text { after the start of the school year. These regulations remain effective until } \\
\text { June 30, 2019. (Reference Assembly Bill 06917, 2013; Senate Bill 04868, } \\
2013 ; \text { New York Education Law } 3637 ; \text { and New York State Education } \\
\text { Department Commissioner's Regulations } 156.3(\mathrm{~h}) \text { ) }\end{array}$ \\
\hline \begin{tabular}{|l|} 
North \\
Carolina
\end{tabular} & \begin{tabular}{|l} 
Laws \& \\
Regulations
\end{tabular} & $\begin{array}{l}\text { School Bus Idle Reduction Requirement All local boards of education in } \\
\text { North Carolina have adopted idle reduction policies prohibiting school buses } \\
\text { from idling unnecessarily on school grounds or warming up for longer than } \\
\text { five minutes. For more information, including a sample policy and } \\
\text { administrative procedure, see http://www.ncbussafety. org/Idling.html. }\end{array}$ \\
\hline \begin{tabular}{|l} 
North \\
Carolina
\end{tabular} & \begin{tabular}{|l} 
State \\
Incentive
\end{tabular} & $\begin{array}{l}\text { Alternative Fuel Vehicle (AFV) and Hybrid Electric Vehicle (HEV) } \\
\text { Support The Clean Fuel Advanced Technology (CFAT) project provides } \\
\text { grant funding to reducing transportation- related emissions in non- } \\
\text { attainment and maintenance counties for National Ambient Air Quality } \\
\text { Standards. A project that is adjacent to these areas may also be eligible for } \\
\text { funding if the project will reduce emissions in eligible counties. The North } \\
\text { Carolina Department of Transportation funds the CFAT project, which } \\
\text { covers three broad areas: education and outreach; project funding; and } \\
\text { recognition of exemplary activities. For } 2013-2016 \text { funding cycles, financial } \\
\text { support is anticipated to be available for AFVs, fueling infrastructure, idle } \\
\text { reduction technologies, heavy-duty HEVs, heavy-duty buses, and } \\
\text { diesel retrofits. For more information, including current requests for } \\
\text { proposals, see http://nccleantech.ncsu.edu/clean-transportation/clean- } \\
\text { transportation-projects/clean-fuel-advanced- technology-project/. }\end{array}$ \\
\hline \begin{tabular}{|l|} 
North \\
Carolina
\end{tabular} & \begin{tabular}{|l} 
State \\
Incentive
\end{tabular} & $\begin{array}{l}\text { Alternative Fuel and Idle Reduction Grants The North Carolina } \\
\text { Department of Environment and Natural Resources Division of Air Quality } \\
\text { provides grants for the incremental cost of purchasing original equipment } \\
\text { manufacturer alternative fuel vehicles, vehicle conversions, and }\end{array}$ \\
\hline
\end{tabular}




\begin{tabular}{|c|c|c|}
\hline & & $\begin{array}{l}\text { implementing idle reduction programs. No grant funding is currently } \\
\text { available (verified October 2013). For more information see the Diesel } \\
\text { Emission Reductions Grants website (http://www.ncair.org/motor/DERG/). }\end{array}$ \\
\hline \begin{tabular}{|l|} 
North \\
Carolina
\end{tabular} & $\begin{array}{l}\text { State } \\
\text { Incentive }\end{array}$ & $\begin{array}{l}\text { Idle Reduction Technology Rebates The North Carolina Department of } \\
\text { Environment and Natural Resources (NCDENR) offers rebates of up to } \\
\$ 2,500 \text { for approved idle reduction technologies through the Idle Reduction } \\
\text { Devices Rebate Program. Eligible technologies must be purchased after } \\
\text { January } 1,2009 \text {, and approved by the U.S. Environmental Protection } \\
\text { Agency or California Air Resources Board. Businesses may receive a } \\
\text { maximum of six rebates, and NCDENR gives priority to individuals or } \\
\text { businesses that have not previously received a rebate. Additional } \\
\text { restrictions apply. Rebates will be available until September 30, 2014, or } \\
\text { until funding is exhausted. For more information, including remaining funds, } \\
\text { see http://www.ncair.org/motor/Rebates/. }\end{array}$ \\
\hline Ohio & \begin{tabular}{|l|} 
State \\
Incentive
\end{tabular} & $\begin{array}{l}\text { Diesel Emissions Reduction Grant Program The Ohio Environmental } \\
\text { Protection Agency administers a Diesel Emissions Reduction Grant Program } \\
\text { (http://www.epa.ohio.gov/oeef/EnvironmentalEducation.aspx\#131364252- } \\
\text { diesel-emission-reduction- grants) for the purpose of reducing emissions } \\
\text { from diesel engines in trucks, school and transit buses, marine fleets, and } \\
\text { locomotives, as well as highway construction equipment. Eligible entities } \\
\text { may use this funding for projects related to certified engine configurations, } \\
\text { including new, rebuilt, or remanufactured engine configurations the U.S. } \\
\text { Environmental Protection Agency or the California Air Resources Board has } \\
\text { certified; the purchase or use of hybrid electric and alternative fuel vehicles } \\
\text { that are allowed under U.S. Federal Highway Administration Congestion } \\
\text { Mitigation and Air Quality (CMAQ) program guidance; or installation of } \\
\text { verified technology including pollution control devices, retrofits, and } \\
\text { development of truck stop electrification and auxiliary power units. To be } \\
\text { eligible for funding, fleets must operate at least } 65 \% \text { of the time in Ohio } \\
\text { counties that have been designated non-attainment or maintenance for } \\
\text { particulate matter (PM) } 2.5 \text { and/or ozone. Private fleets are eligible, but } \\
\text { they must establish a public-private partnership with a government } \\
\text { organization that is eligible for CMAQ funds To apply for funding. A } \\
\text { minimum } 20 \% \text { non-state and non- federal funding match is required. } \\
\text { (Reference Ohio Revised Code } 122.861 \text { ) }\end{array}$ \\
\hline Ohio & $\begin{array}{l}\text { State } \\
\text { Incentive }\end{array}$ & $\begin{array}{l}\text { School Bus Retrofit Grant Program The Ohio Environmental Protection } \\
\text { Agency (EPA) administers the Clean Diesel School Bus Fund Retrofits Grant } \\
\text { Program, which offers grants to retrofit school buses operating on diesel } \\
\text { fuel. Priority is given to school districts in communities that do not meet the } \\
\text { federal air quality standards for fine air particulates and districts that } \\
\text { employ anti-idling policies to reduce emissions from their school bus fleets. } \\
\text { For more information, see http://epa.ohio.gov/oee/ } \\
\text { EnvironmentalEducation.aspx\#LiveTabsContent131361. }\end{array}$ \\
\hline Oklahoma & \begin{tabular}{|l} 
State \\
Incentive
\end{tabular} & $\begin{array}{l}\text { Idle Reduction Weight Exemption Any vehicle equipped with idle } \\
\text { reduction technology may exceed the state's gross vehicle weight limits by } \\
\text { up to } 400 \text { pounds to compensate for the additional weight of the idle } \\
\text { reduction technology. The additional weight may not exceed the actual } \\
\text { certified weight of the idle reduction unit. Upon request, vehicle operators } \\
\text { must provide proof that the idle reduction technology is fully functional. } \\
\text { (Reference Oklahoma Statutes } 47-14-109 \text { ) }\end{array}$ \\
\hline Oklahoma & \begin{tabular}{|l} 
State \\
Incentive
\end{tabular} & $\begin{array}{l}\text { Clean Diesel Fleet Vehicle Grants The Oklahoma Department of } \\
\text { Environmental Quality (DEQ) Air Quality Division provides grants to help } \\
\text { public and private fleets retrofit or replace diesel vehicles to reduce diesel } \\
\text { emissions and improve fuel efficiency. Eligible projects include installation } \\
\text { of idle reduction or aerodynamic technology and diesel vehicle } \\
\text { replacement. Funding is currently not available for this incentive (verified } \\
\text { July 2015). For more information, see http://www.deq.state.ok.us/ } \\
\text { aqdnew/cleandiesel/index.html. }\end{array}$ \\
\hline
\end{tabular}




\begin{tabular}{|c|c|c|}
\hline Oregon & \begin{tabular}{|l} 
State \\
Incentive
\end{tabular} & $\begin{array}{l}\text { Idle Reduction Weight Exemption A vehicle equipped with a fully } \\
\text { functional idle reduction system designed to reduce fuel use and emissions } \\
\text { from engine idling may exceed the maximum weight limitations by up to } \\
400 \text { pounds to accommodate the added weight of the idle reduction } \\
\text { technology. (Reference Oregon Revised Statutes } 818.030 \text { ) }\end{array}$ \\
\hline Oregon & \begin{tabular}{|l} 
State \\
Incentive
\end{tabular} & $\begin{array}{l}\text { Alternative Fuel Loans The Oregon Department of Energy administers } \\
\text { the State Energy Loan Program (SELP) which offers low- interest loans for } \\
\text { qualified projects. Eligible alternative fuel projects include fuel production } \\
\text { facilities, dedicated feedstock production, fueling infrastructure, and fleet } \\
\text { vehicles. Loan recipients must complete a loan application and pay a loan } \\
\text { application fee. For more information, including application forms and } \\
\text { interest rate and fee information, see http://www.oregon.gov/energy/ } \\
\text { LOANS/pages/index.aspx. (Reference Oregon Revised Statutes 470) }\end{array}$ \\
\hline Oregon & \begin{tabular}{|l|} 
Laws \& \\
Regulations
\end{tabular} & $\begin{array}{l}\text { Commercial Vehicle Idle Reduction Requirement A driver of a } \\
\text { commercial vehicle may not idle the engine for more than five minutes in } \\
\text { any sixty-minute period, unless the vehicle is using an auxiliary power unit, } \\
\text { generator set, cargo temperature control unit, or other idle reduction } \\
\text { technology that maintains heat or air conditioning or provides electrical } \\
\text { power. Exceptions apply in certain situations and for certain vehicles. } \\
\text { (Reference Oregon Revised Statutes } 825.605 \text { through } 825.610 \text { ) }\end{array}$ \\
\hline Pennsylvania & \begin{tabular}{|l} 
Laws \& \\
Regulations
\end{tabular} & $\begin{array}{l}\text { Idle Reduction Requirement Diesel vehicles with a gross vehicle weight } \\
\text { rating over } 10,000 \text { pounds may not idle for more than five minutes in any } \\
\text { continuous } 60 \text { minute period. Exemptions include: uncontrollable traffic } \\
\text { conditions; prevention of safety or health emergencies; emergency or law } \\
\text { enforcement purposes; verification that a vehicle is safe to operate; vehicle } \\
\text { maintenance; power work-related operations; sampling, weighing, or } \\
\text { loading; bus passenger comfort; vehicles actively engaged in solid waste or } \\
\text { recyclable material collection; vehicles complying with manufacturer } \\
\text { specifications; and vehicles meeting California Air Resources Board nitrogen } \\
\text { oxide idling emission standards. (Reference Title } 35 \text { Pennsylvania Statutes, } \\
\text { Chapter 23B, Section } 4603 \text { ) }\end{array}$ \\
\hline Pennsylvania & \begin{tabular}{|l} 
State \\
Incentive
\end{tabular} & $\begin{array}{l}\text { Idle Reduction Weight Exemption A vehicle equipped with qualified idle } \\
\text { reduction technology may exceed the state's gross weight and axle weight } \\
\text { limits by up to } 400 \text { pounds to compensate for the additional weight of the } \\
\text { idle reduction technology. (Reference Title } 35 \text { Pennsylvania Statutes, } \\
\text { Chapter } 23 B \text {, Section } 4604 \text { ) }\end{array}$ \\
\hline Pennsylvania & \begin{tabular}{|l} 
State \\
Incentive
\end{tabular} & $\begin{array}{l}\text { Alternative Fuel and Idle Reduction Grants The Small Business } \\
\text { Advantage Grant Program provides matching grants of } 50 \% \text {, up to } \$ 9,500, \\
\text { to enable a Pennsylvania small business to adopt or acquire energy-efficient } \\
\text { or pollution prevention equipment or processes. Pennsylvania trucking } \\
\text { companies and independent truckers may use the funding to purchase } \\
\text { auxiliary power units. Projects may not begin until after applications are } \\
\text { approved. Funding is contingent upon annual legislative appropriations. The } \\
\text { Fiscal Year } 2014 \text { application period is open until April15, 2015, or until } \\
\text { funds have been fully committed (verified October } 2014 \text { ). For more } \\
\text { information, refer to http://www.portal.state.pa.us/portal/server.pt/ } \\
\text { community/small business ombudsman/10493. }\end{array}$ \\
\hline Pennsylvania & \begin{tabular}{|l} 
State \\
Incentive
\end{tabular} & $\begin{array}{l}\text { Idle Reduction Loans The Small Business Pollution Prevention } \\
\text { Assistance Account Loan Program provides low interest rate loans to small } \\
\text { businesses undertaking projects in Pennsylvania that reduce waste, } \\
\text { pollution, or energy use, including the purchase of truck auxiliary power } \\
\text { units. Loans are available for } 75 \% \text { of the total eligible project costs. The } \\
\text { maximum loan amount is } \$ 100,000 \text { within any } 12 \text {-month period. The loan } \\
\text { has a } 2 \% \text { fixed rate and a maximum term of } 10 \text { years. For more } \\
\text { information, refer to http://www.portal.state.pa.us/portal/ } \\
\text { server.pt?open }=514 \& \text { objID }=553247 \& \text { mode }=2 \text { ). }\end{array}$ \\
\hline
\end{tabular}




\begin{tabular}{|c|c|c|}
\hline Rhode Island & $\begin{array}{l}\text { Laws \& } \\
\text { Regulations }\end{array}$ & $\begin{array}{l}\text { State Agency Coordination to Address Climate Change The Rhode } \\
\text { Island Climate Change Coordinating Council (Council) was established to } \\
\text { coordinate efforts between state agencies to reduce greenhouse gas (GHG) } \\
\text { emissions. With assistance from the Council, state agencies will develop } \\
\text { programs to encourage state employees to reduce vehicle miles traveled } \\
\text { and use public transportation when available. The Council will also work } \\
\text { with municipalities to encourage sustainability; identify federal, state, and } \\
\text { private funding opportunities that can be leveraged to reduce emissions in } \\
\text { Rhode Island; and develop GHG emissions reduction strategies. The } \\
\text { Council will submit a plan with suggested strategies for GHG emissions } \\
\text { reduction activities to the governor no later than December } 31,2016 \text {. } \\
\text { (Reference Senate Bill } 2952,2014 \text {, and Rhode Island General Laws 42-6.2) }\end{array}$ \\
\hline Rhode Island & \begin{tabular}{|l|} 
Laws \& \\
Regulations
\end{tabular} & $\begin{array}{l}\text { Emissions Control Requirement Heavy-duty diesel vehicles used to } \\
\text { perform federally funded state public works contracts must be powered by } \\
\text { engines with Level } 3 \text { emissions control devices that are properly operated } \\
\text { and maintained. If the Rhode Island Department of Environmental } \\
\text { Management determines that no verified Level } 3 \text { devices are appropriate on } \\
\text { particular engines, Level } 2 \text { devices are required. Likewise, if no verified } \\
\text { Level } 2 \text { devices are appropriate, Level } 1 \text { devices are required. Exceptions to } \\
\text { this requirement include, but are not limited to snow removal vehicles and } \\
\text { equipment, farm equipment, emergency response vehicles, standby } \\
\text { generators, and vehicles used on a project for < } 30 \text { total work days over } \\
\text { the life of the project. (Reference Rhode Island General Laws } 31-47.3-5 \text { ) }\end{array}$ \\
\hline Rhode Island & \begin{tabular}{|l} 
Laws \& \\
Regulations
\end{tabular} & $\begin{array}{l}\text { Idle Reduction Requirement Motor vehicles may not idle unnecessarily } \\
\text { for longer than five consecutive minutes during any } 60 \text { minute period. This } \\
\text { includes heavy-duty diesel vehicles used to perform any state public works } \\
\text { contracts. Unnecessary idling does not include circumstances exempted by } \\
\text { regulations the Rhode Island Department of Environmental Management } \\
\text { (DEM) has adopted, such as when it is necessary to operate heating and } \\
\text { cooling equipment to ensure the health or safety of drivers and passengers. } \\
\text { Other vehicles exempt from these requirements include, but are not limited } \\
\text { to, the following: } 1 \text { ) emergency response, public safety, or military } \\
\text { vehicles; } 2 \text { ) armored vehicles being loaded or unloaded; } 3 \text { ) non-road } \\
\text { vehicles; and } 4 \text { ) vehicles making deliveries of fuel or energy products. } \\
\text { Violators of these regulations will be fined up to } \$ 100 \text { for the first offense } \\
\text { and up to } \$ 500 \text { for each succeeding offense. (Reference Rhode Island } \\
\text { General Laws } 23-23-29.2 \text { and } 31-16.1 \text { ) }\end{array}$ \\
\hline \begin{tabular}{|l} 
South \\
Carolina
\end{tabular} & \begin{tabular}{|l} 
State \\
Incentive
\end{tabular} & $\begin{array}{l}\text { Idle Reduction Weight Exemption Any motor vehicle or combination } \\
\text { of vehicles equipped with idle reduction technology is allowed to exceed } \\
\text { the maximum gross vehicle and axle weight limits by up to } 400 \text { pounds } \\
\text { to compensate for the added weight of the idle reduction technology. } \\
\text { The vehicle operator must provide documentation that the vehicle is } \\
\text { equipped with idle reduction technology. (Reference South Carolina Code } \\
\text { of Laws 56-5-4160) }\end{array}$ \\
\hline \begin{tabular}{|l} 
South \\
Carolina
\end{tabular} & \begin{tabular}{|l} 
State \\
Incentive
\end{tabular} & $\begin{array}{l}\text { Clean Energy Advisory Commission The South Carolina Clean Energy } \\
\text { Industry Manufacturing Market Development Advisory Commission } \\
\text { (Commission) will assist with the development of clean energy technologies, } \\
\text { materials, and products, including advanced vehicle, alternative } \\
\text { transportation fuel, battery manufacturing, and hydrogen fuel cell } \\
\text { industries. The Commission will provide an initial report by December } 31, \\
2014 \text {, to the governor and the general assembly, with a description and } \\
\text { analysis of the existing clean energy manufacturing industry, job } \\
\text { development potential, market potential, incentives offered by neighboring } \\
\text { states, and recommendations for in-state production incentives, } \\
\text { benchmarks to increase clean energy manufacturing, and marketing and } \\
\text { public education programs. The Commission must issue a final report by } \\
\text { September } 30,2015 \text {. (Reference House Bill } 3125,2014 \text {, and South Carolina } \\
\text { Code of Laws } 11-55-100)\end{array}$ \\
\hline
\end{tabular}




\begin{tabular}{|c|c|c|}
\hline $\begin{array}{l}\text { South } \\
\text { Carolina }\end{array}$ & \begin{tabular}{|l} 
Laws \& \\
Regulations
\end{tabular} & $\begin{array}{l}\text { Idle Reduction Requirement Vehicle operators may not idle any } \\
\text { commercial diesel vehicle with a gross vehicle weight rating of more than } \\
10,000 \text { pounds for more than } 10 \text { minutes in any one-hour period. } \\
\text { Exemptions apply for the following: traffic conditions; prevention of safety } \\
\text { or health emergencies; emergency or law enforcement; maintenance, } \\
\text { service, repair, or diagnostic purposes; state or federal inspections; power } \\
\text { work-related operations; loading or unloading; sleeper berth temperature } \\
\text { control during 1) rest or sleep periods, } 2 \text { ) times when the ambient outside } \\
\text { air temperature is less than } 40 \text { degrees F or greater than } 80 \text { degrees F, or } \\
3 \text { ) at rest areas, terminals, truck stops, or legal parking locations greater } \\
\text { than } 500 \text { feet from homes, schools, hospitals, or daycare facilities. } \\
\text { Violators are subject to a } \$ 75 \text { fine for each offense. (Reference South } \\
\text { Carolina Code of Laws } 56-35-10 \text { to } 56-35-80 \text { ) }\end{array}$ \\
\hline Tennessee & \begin{tabular}{|l} 
State \\
Incentive
\end{tabular} & $\begin{array}{l}\text { Idle Reduction Weight Exemption Any motor vehicle equipped with } \\
\text { qualified idle reduction technology or other emissions reduction technology } \\
\text { may exceed the state gross or axle weight limits, by the larger of } 550 \\
\text { pounds or the maximum amount allowed by federal law to account for the } \\
\text { weight of the technology. The additional weight may not exceed the actual } \\
\text { weight of the idle reduction unit. The vehicle operator must also be able to } \\
\text { demonstrate that the technology is fully functional. (Reference Tennessee } \\
\text { Code 55-7-203) }\end{array}$ \\
\hline Texas & \begin{tabular}{|l} 
State \\
Incentive
\end{tabular} & $\begin{array}{l}\text { Clean Vehicle and Infrastructure Grants The Texas Commission on } \\
\text { Environmental Quality (TCEQ) administers the Emissions Reduction } \\
\text { Incentive Grants (ERIG) Program as part of the Texas Emissions } \\
\text { Reduction Plan. The ERIG Program provides grants for various types of } \\
\text { clean air projects to improve air quality in the state's nonattainment } \\
\text { areas. Eligible projects include those that involve replacement, retrofit, } \\
\text { repower, or lease or purchase of new heavy-duty vehicles; alternative } \\
\text { fuel dispensing infrastructure; idle reduction and electrification } \\
\text { infrastructure; and alternative fuel use. Funds are not currently available } \\
\text { for fiscal year 2015-2016 (verified July 2015). For more information, } \\
\text { including funding availability, see http://www.tceq.state.tx.us/ } \\
\text { implementation/air/terp/erig.html. (Reference Texas Statutes, Health } \\
\text { and Safety Code 386) }\end{array}$ \\
\hline Texas & \begin{tabular}{|l} 
Laws \& \\
Regulations
\end{tabular} & $\begin{array}{l}\text { Idle Reduction Requirement A vehicle may not idle for more than five } \\
\text { minutes from April through October in cities and counties where the local } \\
\text { government has signed a Memorandum of Agreement with the Texas } \\
\text { Commission on Environmental Quality (TCEQ). Exemptions apply for the } \\
\text { following: vehicles with a gross vehicle weight rating (GVWR) of 14,000 } \\
\text { pounds (Ibs.) or less; emergency or law enforcement vehicles; airport } \\
\text { ground support vehicles; rented/leased vehicles; to perform needed work, } \\
\text { including maintenance and diagnostics; to defrost a windshield; traffic } \\
\text { conditions; and hours of service compliance activities. Vehicles may idle for } \\
\text { up to } 30 \text { minutes for bus passenger comfort or transit operations. Fines } \\
\text { vary by jurisdiction. TCEQ may not prohibit or limit the idling of any vehicle } \\
\text { with a GVWR greater than } 8,500 \text { lbs. provided that the vehicle is equipped } \\
\text { with a } 2008 \text { or subsequent model year heavy-duty diesel or natural gas } \\
\text { engine that is certified by the U.S. Environmental Protection Agency or } \\
\text { another state agency to emit no more than } 30 \text { grams of nitrogen oxides per } \\
\text { hour when idling. (Reference Texas Statutes, Health and Safety Code } \\
382.0191 \text {; and Texas Administrative Code } 30.114 .510 \text { through 30.114.517) }\end{array}$ \\
\hline Texas & \begin{tabular}{|l} 
State \\
Incentive
\end{tabular} & $\begin{array}{l}\text { Idle Reduction Weight Exemption Any vehicle equipped with qualifying } \\
\text { idle reduction technology may exceed the state's gross vehicle weight limits } \\
\text { by up to } 400 \text { pounds to compensate for the additional weight of the idle } \\
\text { reduction technology. Upon request, vehicle operators must provide proof } \\
\text { that the idle reduction technology is fully functional. (Reference Texas } \\
\text { Statutes, Transportation Code 622.955) }\end{array}$ \\
\hline
\end{tabular}




\begin{tabular}{|c|c|c|}
\hline Utah & \begin{tabular}{|l} 
Laws \& \\
Regulations
\end{tabular} & $\begin{array}{l}\text { School Bus Idle Reduction Regulations School bus drivers must } \\
\text { turn off bus engines as soon as possible at loading and unloading areas } \\
\text { and only restart the engine when it is time to depart. Exceptions include } \\
\text { extreme weather conditions and idling in traffic. At bus depots, drivers } \\
\text { are required to limit engine warm-up to the time recommended by the } \\
\text { engine manufacturer. All school bus drivers in the state receive a } \\
\text { minimum of } 30 \text { minutes of idling reduction instruction during their } \\
\text { annual service training. In addition, school districts must revise } \\
\text { bus schedules to maximize efficiency and assign the cleanest buses to } \\
\text { the longest routes. (Reference Utah Code } 41-6 a-1308, \text { Utah } \\
\text { Administrative Code } 277-601-1 \text { through } 277-601-3 \text {, and Standards for } \\
\text { Utah School Buses and Operations, http://www.schools.utah.gov/ } \\
\text { finance/Pupil-Transportation.aspx) }\end{array}$ \\
\hline Utah & \begin{tabular}{|l} 
Laws \& \\
Regulations
\end{tabular} & $\begin{array}{l}\text { Local Vehicle Idling Regulations A local highway authority may not } \\
\text { enact an ordinance that prohibits or restricts an owner or operator of a } \\
\text { vehicle from idling the vehicle's engine, unless the ordinance is primarily } \\
\text { educational, specifies that a person must be issued at least three warnings } \\
\text { before a fine is imposed, has the same fine structure as a parking violation, } \\
\text { provides for the safety of law enforcement personnel enforcing the } \\
\text { ordinance, and specifies that the ordinance may be enforced on public } \\
\text { property or private property that is open to the general public. Exceptions } \\
\text { apply. (Reference Utah Code 41-6a-208) }\end{array}$ \\
\hline Utah & \begin{tabular}{|l} 
Laws \& \\
Regulations
\end{tabular} & $\begin{array}{l}\text { Idle Reduction Requirement Idling of any unattended vehicle is } \\
\text { prohibited in Utah. Violators are subject to a penalty of up to } \$ \$ 750 \text { and/or } \\
\text { up to } 90 \text { days imprisonment. Drivers on state roads are also encouraged to } \\
\text { avoid excessive idling, which, as a general rule, is defined as more than } 10 \\
\text { to } 15 \text { seconds for passenger vehicles. Specifically, drivers are encouraged } \\
\text { to turn off engines when loading or unloading, delivering, and picking up or } \\
\text { dropping off passengers. Drivers of gasoline powered passenger vehicles } \\
\text { are encouraged to limit engine warm-up time to } 30 \text { seconds and drivers of } \\
\text { diesel powered passenger vehicles, buses, and trucks are encouraged to } \\
\text { limit engine warm-up to the time the vehicle manufacturer recommends, } \\
\text { which is generally less than five minutes. Businesses, schools, airport } \\
\text { authorities, and governmental entities are encouraged to post signs to } \\
\text { discourage customer idling. (Reference Utah Code } 41-6 a-202, \\
41-6 a-1403,76-3-204 \text {, and } 76-3-301 \text { ) }\end{array}$ \\
\hline Vermont & $\begin{array}{l}\text { Laws \& } \\
\text { Regulations }\end{array}$ & $\begin{array}{l}\text { State Agency Energy Plan Transportation Requirements The } \\
\text { Vermont Agency of Administration developed and oversees the } \\
\text { implementation of the State Agency Energy Plan (Plan). The Agency of } \\
\text { Administration must modify the Plan as necessary and re- adopt it on or } \\
\text { before January } 15 \text { of each fifth year. As specified in the } 2010 \text { Plan } \\
\text { (http://bgs.vermont.gov/sites/bgs/files/pdfs/BGS-VTStateEnergyPlan.pdf), } \\
\text { the Vermont Agency of Transportation must continue to use } 5 \% \text { biodiesel } \\
\text { (B5) in its fleet of heavy-duty vehicles. The Vermont Department of } \\
\text { Buildings and General Services must continue to use hybrid electric vehicles } \\
\text { and Partial Zero Emission Vehicles in its fleet, while adjusting purchases } \\
\text { based on annual fleet selection monitoring and available vehicle technology. } \\
\text { All state agencies must investigate the use of additional alternative fuel and } \\
\text { advanced technology vehicles, as well as the necessary fueling } \\
\text { infrastructure, such as incorporating electric vehicle supply equipment at } \\
\text { appropriate state facilities. The Plan specifies the responsibilities of the } \\
\text { Climate Neutral Working Group (CNWG). All state government agencies, } \\
\text { offices, and departments must purchase the most fuel-efficient vehicles } \\
\text { available in each vehicle class according to specifications set by the CNWG. } \\
\text { The CNWG must consider vehicles that meet high fuel economy standards } \\
\text { and emit reduced levels of greenhouse gases, criteria pollutants, and } \\
\text { hazardous air contaminants. Additionally, the CNWG must expand education } \\
\text { and tracking related to anti-idling campaigns for state fleet vehicles and } \\
\text { private sector vehicles operating on state owned property, and conduct a }\end{array}$ \\
\hline
\end{tabular}




\begin{tabular}{|c|c|c|}
\hline & & $\begin{array}{l}\text { survey to determine the level of government employee participating in } \\
\text { carpooling, vanpooling, and other commuting options. Progress towards } \\
\text { these goals is outlined in the CNWG Biennial Reports (http://www.anr.state } \\
\text { vt.us/anr/climatechange/Library.html). (Reference Vermont Statutes Title } \\
\text { 3, Chapter } 45 \text {, Section } 2291 \text {, and Executive Order } 15-12,2012 \text { ) }\end{array}$ \\
\hline Vermont & \begin{tabular}{|l} 
Laws \& \\
Regulations
\end{tabular} & $\begin{array}{l}\text { Idle Reduction Requirements A driver may not idle a motor vehicle for } \\
\text { more than five minutes in a } 60 \text {-minute period. This limit does not apply if } \\
\text { the vehicle is operating an auxiliary power unit, generator set, or other } \\
\text { mobile idle reduction technology. Additional exemptions apply. Additionally, } \\
\text { all driver education courses must include instruction on the adverse } \\
\text { environmental, health, economic, and other impacts of unnecessary idling } \\
\text { and on the law governing idling of motor vehicles. (Reference Vermont } \\
\text { Statutes Title 23, Chapter } 13 \text {, Section } 1110 \text {; and Title 16, Chapter 23, } \\
\text { Section 1045) }\end{array}$ \\
\hline Vermont & \begin{tabular}{|l} 
Laws \& \\
Regulations
\end{tabular} & $\begin{array}{l}\text { School Bus Idle Reduction Requirement School bus operators must } \\
\text { turn off the bus engine immediately after arriving at a student loading and } \\
\text { unloading area located on school grounds, and may not start the engine } \\
\text { until the bus is ready to leave the school grounds. In addition, operators } \\
\text { may not idle the engine for more than five minutes in a } 60-\text { minute period } \\
\text { on school grounds. Exceptions include periods when the engine is necessary } \\
\text { to operate special equipment for disabled persons; to address safety, } \\
\text { traffic, health, or emergency concerns; or to service the vehicle. (Reference } \\
\text { Vermont State Board of Education Rules and Practices } 6001 \text { through } \\
6005 \text {, and Vermont Statutes Title 23, Chapter 13, Section 1282) }\end{array}$ \\
\hline Virginia & $\begin{array}{l}\text { State } \\
\text { Incentive }\end{array}$ & $\begin{array}{l}\text { Idle Reduction and Natural Gas Vehicle (NGV) Weight Exemption } \\
\text { Any motor vehicle equipped with an auxiliary power unit or other idle } \\
\text { reduction technology may exceed the gross, single axle, tandem axle, or } \\
\text { bridge formula weight limits by up to } 550 \text { pounds to compensate for the } \\
\text { added weight of the idle reduction technology. Furthermore, any NGV may } \\
\text { exceed the limits by up to } 2,000 \text { pounds. (Reference Virginia Code } 46.2- \\
1129.1 \text { through } 46.2-1129.2 \text { ) }\end{array}$ \\
\hline Virginia & \begin{tabular}{|l|} 
Laws \& \\
Regulations
\end{tabular} & $\begin{array}{l}\text { Idle Reduction Requirement Motor vehicles licensed for commercial or } \\
\text { public service may not idle for more than three minutes in commercial or } \\
\text { residential urban areas, unless the engine is providing auxiliary power for } \\
\text { purposes other than heating or air conditioning. Tour buses and diesel } \\
\text { vehicles are not permitted to idle for more than } 10 \text { minutes. (Reference } \\
\text { Virginia Administrative Code } 9-5-40-5670(C) \text { ) }\end{array}$ \\
\hline Washington & $\begin{array}{l}\text { Utility/ } \\
\text { Private } \\
\text { Incentive }\end{array}$ & $\begin{array}{l}\text { Clean and Efficient Fleet Assistance Western Washington Clean Cities } \\
\text { and the Puget Sound Clean Air Agency administer the Evergreen Fleets } \\
\text { program (http://www.evergreenfleets.org/), a comprehensive greening plan } \\
\text { and certification system for fleets. Evergreen Fleets provides fleet managers } \\
\text { with tools to help "green" public and private fleets, reduce pollution, and } \\
\text { save money. Evergreen Fleets provides a step-by-step guide to identify the } \\
\text { most effective way for fleet managers to green their fleets, including buying } \\
\text { greener vehicles, switching to cleaner fuels, or improving fleet efficiency. }\end{array}$ \\
\hline Washington & \begin{tabular}{|l} 
Laws \& \\
Regulations
\end{tabular} & $\begin{array}{l}\text { Establishment of Idle Reduction Loan Program The Washington } \\
\text { Department of Ecology will establish a loan program for investments in } \\
\text { diesel idle reduction technologies, including truck stop electrification, } \\
\text { auxiliary power units, cab air heaters, battery-powered heating and air } \\
\text { conditioning systems, automatic engine start-up and shutdown systems, } \\
\text { and projects that augment or replace diesel engines or power systems with } \\
\text { liquefied or compressed natural gas engines or systems. The Department } \\
\text { will offer low or no interest loans state, local, or other governmental entities } \\
\text { that own diesel vehicles or equipment. Only vehicles that spend at least one } \\
\text { half of their time operating in Washington are eligible. The Department will } \\
\text { evaluate projects based on human health, environmental, and greenhouse } \\
\text { gas benefits. (Reference Revised Code of Washington 70.325.030) }\end{array}$ \\
\hline
\end{tabular}




\begin{tabular}{|c|c|c|}
\hline Washington & \begin{tabular}{|l} 
State \\
Incentive
\end{tabular} & $\begin{array}{l}\text { Idle Reduction Weight Exemption A motor vehicle equipped with a fully } \\
\text { functional idle reduction system designed to reduce fuel use and } \\
\text { emissions from engine idling may exceed the state maximum weight } \\
\text { limitations by up to } 400 \text { lbs to compensate for the added weight of the idle } \\
\text { reduction technology. The vehicle operator must provide written } \\
\text { certification of the weight of the technology and demonstrate the } \\
\text { technology is fully functional. (Reference Washington Administrative Code } \\
468-38-073 \text { ) }\end{array}$ \\
\hline Washington & \begin{tabular}{|l} 
State \\
Incentive
\end{tabular} & $\begin{array}{l}\text { Idle Reduction Tax Incentives and Exemptions Tax incentives are } \\
\text { available for the infrastructure and services that support the use of auxiliary } \\
\text { power for vehicles with gross vehicle weight ratings of more than } 14,000 \\
\text { pounds through on-board or stand- alone electrification systems. These } \\
\text { incentives include a business and occupation tax deduction and a sales and } \\
\text { tax exemption for machinery and equipment used to provide auxiliary } \\
\text { power at truck stops. Sales and use tax exemptions are also available for } \\
\text { any parts and labor necessary to enable heavy-duty diesel trucks to accept } \\
\text { power for onboard electrification systems. These exemptions expire July } 1 \text {, } \\
\text { 2015. (Reference Revised Code of Washington } 82.04 .4338,82.08 .815, \\
82.08 .825,82.12 .815, \text { and } 82.12 .825 \text { ) }\end{array}$ \\
\hline West Virginia & $\begin{array}{l}\text { State } \\
\text { Incentive }\end{array}$ & $\begin{array}{l}\text { Idle Reduction Weight Exemption Any motor vehicle equipped with } \\
\text { qualified idle reduction technology may exceed the state gross and axle } \\
\text { weight limits by up to } 550 \text { pounds, as provided under Title } 23 \text { U.S. Code, } \\
\text { section } 127(\text { a)(12), to compensate for the added weight of the idle } \\
\text { reduction technology. (Reference West Virginia Code } 17 \mathrm{C}-13 \mathrm{~A}-4 \text { ) }\end{array}$ \\
\hline West & \begin{tabular}{|l} 
Laws \& \\
Regulations
\end{tabular} & $\begin{array}{l}\text { Idle Reduction Requirement A commercial motor vehicle with a gross } \\
\text { vehicle weight rating of } 10,001 \text { pounds or more may not idle for more than } \\
15 \text { minutes in any } 60 \text {-minute period. Exceptions apply, including those } \\
\text { pertaining to emergency vehicles, auxiliary power unit use, and outside } \\
\text { temperature. Additionally, exemptions apply to diesel vehicles with a label } \\
\text { issued by the California Air Resources Board and diesel vehicles powered by } \\
\text { clean diesel technology or biodiesel. (Reference West Virginia Code } 17 \mathrm{C} \text { - } \\
13 \mathrm{~A}-1 \text { through } 17 \mathrm{C}-13 \mathrm{~A}-3 \text { ) }\end{array}$ \\
\hline Wisc & \begin{tabular}{|l} 
State \\
Incentive
\end{tabular} & $\begin{array}{l}\text { Idle Reduction Weight Exemption Any vehicle or combination of } \\
\text { vehicles equipped with fully functional idle reduction technology may exceed } \\
\text { the state's gross and axle weight limits by up to } 400 \text { pounds (Ibs) to } \\
\text { compensate for the additional weight of the idle reduction technology. To } \\
\text { qualify, the vehicle operator must be able to prove the weight of the idle } \\
\text { reduction technology with written certification and demonstrate that the idle } \\
\text { reduction technology is fully functional at all times. (Reference Wisconsin } \\
\text { Statutes } 348.15(3)(f) \text { ) }\end{array}$ \\
\hline Wisc & \begin{tabular}{|l} 
State \\
Incentive
\end{tabular} & $\begin{array}{l}\text { Idle Reduction Grant Program The Wisconsin Dept. of Administration } \\
\text { provides idle reduction grants to eligible common, contract, and private } \\
\text { motor carriers headquartered in Wisconsin that transport freight. Applicants } \\
\text { may receive grants of up to } 50 \% \text { of the cost of equipment and installation } \\
\text { on heavy-duty truck tractors produced in Model Year } 1999 \text { or later. Other } \\
\text { conditions may apply. The grant program provides } \$ 1 \text { million for each } \\
\text { budget cycle. The application for the } 2013-2014 \text { funding cycle is no longer } \\
\text { available (verified November } 2013 \text { ). Funding for the } 2015 \text { cycle has been } \\
\text { approved by the Wisconsin Legislature and will be available on or around } \\
\text { July } 1,2014 \text {. For more information, see } \\
\text { http://www.stateenergyoffice.wi.gov/category.asp?linkcatid=3766\&locid=1 } \\
60 \text {. (Reference Wisconsin Statutes } 560.125 \text { ) }\end{array}$ \\
\hline Wyoming & $\begin{array}{l}\text { Laws \& } \\
\text { Regulations }\end{array}$ & $\begin{array}{l}\text { Idle Reduction Requirement A driver may not idle a vehicle on a } \\
\text { roadway outside a business or residential district when it is practical to stop } \\
\text { and park the vehicle. A driver may not leave a vehicle unattended without } \\
\text { first stopping the engine and removing the key from the ignition. } \\
\text { (Reference Wyoming Statutes } 31-5-505 \text { and } 31-5-509 \text { ) }\end{array}$ \\
\hline
\end{tabular}




\section{References}

(1) What You Should Know About Truck Engine Idling, U.S. Environmental Protection Agency, April 2002. http://www.epa.gov/region1/eco/diesel/pdfs/ Diesel Factsheet Truck Idling.pdf. Accessed Feb. 19, 2015.

(2) Gaines, L., and Levinson, T. "Idling Reduction Makes Sense." Presented by Argonne National Laboratory for DOE Clean Cities Program, September 23, 2009.

(3) Federal Motor Carrier Safety Administration, U. S. Department of Transportation. 49 CFR 395.3 and 49 CFR 395.5. http://www.fmcsa.dot.gov/regulations/title49/section/395.3 Accessed Mar. 13, 2015.

(4) "The Harmful Effects of Vehicle Exhaust, Environment and Human Health, Inc." http://www.ehhi.org/reports/exhaust/summary.shtml. Accessed Mar 24, 2015.

(5) American Lung Association Energy Policy Development: Transportation Background Document, American Lung Association, February 2011. http://www.lung.org/healthyair/outdoor/resources/\%09http:/www.lung.org/healthy- air/outdoor/resources/ transportation-backgrounder.pdf.

(6) U.S. Environmental Protection Agency, 2011 National Emissions Inventory. .http://www.epa.gov/ttn/chief/net/2011inventory.html. Accessed Mar 13, 2015.

(7) U.S. EPA. "Six Common Air Pollutants." http://epa.gov/airquality/urbanair/ Accessed Mar 23, 2015.

(8) Stodolsky, F., Gaines, L., and Vyas, A. "Analysis of Technology Options to Reduce the Fuel Consumption of Idling Trucks." Center for Transportation Research, Argonne National Laboratory, June 2000.

(9) "Idle Reduction and Efficiency." Virginia Clean Cities. http://www.vacleancities.org/cleaner-transportation/idle-reduction. Accessed Feb 16, 2015.

(10) Wikipedia. http://en.wikipedia.org/wiki/Solid oxide fuel cell. Accessed Apr 13, 2015.

(11) Ziring, E. "Impacts of Idling Reduction Devices on Transit Buses: A Preliminary Analysis." Urban Transportation Center, University of Illinois at Chicago, May 21, 2008.

(12) Onboard Idle Reduction Equipment for Heavy-Duty Trucks. Alternative Fuel Data Center, U.S. Department of Energy. http://www.afdc.energy.gov/conserve/idle reduction onboard.html. Accessed Apr 24, 2015.

(13) Gaines, L. "How Do Idling Reduction Options Compare?" Center for Transportation Research, Argonne National Laboratory, Mar 19, 2008.

(14) 2014 Public Transportation Vehicle Database, American Public Transportation Association, 2014.

(15) Average Retail Fuel Prices in the U.S., Alternative Fuel Data Center, U.S. Department of Energy. http://www.afdc.energy.gov/fuels/prices.html. Accessed Aug 17, 2015.

(16) U.S. Department of Energy, Alternative Fuels Data Center. All Laws and Incentives Sorted by Type. Accessed April 15, 2014. http://www.afdc.energy.gov/laws/matrix/incentive.

(17) Clean Cities Petroleum Savings by Idle Reduction. Alternative Fuel Data Center, U.S. Department of Energy, 2014. http://www.afdc.energy.gov/data/ search?q=idle+reduction. Accessed Aug 20, 2015. 
(18) Commercial Bus Emission Characterization and Idle Reduction: Idle \& Urban Cycle Test Results. American Bus Association, Jun 14, 2006.

(19) "Massachusetts Fleet Braun's Express Celebrates 10 Years of Petroleum Reduction Success." Alternative Fuel Data Center, U. S. Department of Energy, Mar 13, 2015. http://www.afdc.energy.gov/case/2065. Accessed Sep 9, 2015.

(20) "The Heat is On in St. Louis Buses." Alternative Fuel Data Center, U. S. Department of Energy, May 24, 2013. http://www.afdc.energy.gov/case/1429. Accessed Sep 9, 2015.

(21) "School Buses Go Green in Virginia." Alternative Fuel Data Center, U. S. Department of Energy, Oct 1, 2011. http://www.afdc.energy.gov/case/1054. Accessed Sep 9, 2015.

(22) "Idle Reduction Case Study." National Alternative Fuels Training Consortium, University of West Virginia, 2012. http://www.naftconline.org/cclptoolbox/ _. prt/idle/Idle Reduction Fleet CS1 WalledLakeSchools.pdf Accessed Sep 23, 2015. 